\title{
Alternate Reductant Cold Cap Evaluation Furnace Phase I Testing
}

F.C. Johnson

D.H. Miller

J.R. Zamecnik

D.P. Lambert

April 2014

SRNL-STT-2014-00005, Revision 0 


\section{DISCLAIMER}

This work was prepared under an agreement with and funded by the U.S. Government. Neither the U.S. Government or its employees, nor any of its contractors, subcontractors or their employees, makes any express or implied:

1. warranty or assumes any legal liability for the accuracy, completeness, or for the use or results of such use of any information, product, or process disclosed; or

2. representation that such use or results of such use would not infringe privately owned rights; or

3. endorsement or recommendation of any specifically identified commercial product, process, or service.

Any views and opinions of authors expressed in this work do not necessarily state or reflect those of the United States Government, or its contractors, or subcontractors.

\section{Printed in the United States of America \\ Prepared for U.S. Department of Energy}


Keywords: alternate reductant, cold cap evaluation furnace (CEF)

Retention: Permanent

\title{
Alternate Reductant Cold Cap Evaluation Furnace Phase I Testing
}

\author{
F.C. Johnson \\ D.H. Miller \\ J.R. Zamecnik \\ D.P. Lambert
}

April 2014

Prepared for the U.S. Department of Energy under 
AUTHORS:

\section{REVIEWS AND APPROVALS}

F.C. Johnson, Process Technology Programs

Date

D.H. Miller, Engineering Process Development

Date

J.R. Zamecnik, Process Technology Programs

Date

D.P. Lambert, Process Technology Programs

Date

TECHNICAL REVIEW:

D.K. Peeler, Process Technology Programs, Reviewed per E7 2.60

Date

J.D. Newell, Process Technology Programs, Reviewed per E7 2.60

Date

J.M. Pareizs, Process Technology Programs, Reviewed per E7 2.60

Date

APPROVAL:

D.H. McGuire, Manager

Date

Process Technology Programs

S.L. Marra, Manager

Date

Environmental \& Chemical Process Technology Research Programs

E.J. Freed, Manager

Date

DWPF \& Saltstone Engineering 


\section{ACKNOWLEDGEMENTS}

The authors would like to thank: Jake Amoroso, David Best, Mona Blume, Jeff Coughlin, Gene Daniel, Mark Duignan, Jon Duvall, Amy Ekechukwu, Mike Feller, Andy Foreman, Mark Fowley, Kevin Fox, John Gordon, Holly Hall, Joel Jones, Dale Marzolf, Bridget Miller, David Mitchell, John Pareizs, Monica Philips, Mike Restivo, Whitney Riley, Dianne Scott, Geoff Smoland, Bill Spencer, John Steimke, Mike Stone, Doug Sumpter, Beverly Wall, Frances Williams, Mike Williams, Joe Wilson, Phyllis Workman and Kim Wyszynski for their support throughout system setup, testing and sample analysis. 


\section{EXECUTIVE SUMMARY}

Savannah River Remediation (SRR) conducted a Systems Engineering Evaluation (SEE) to determine the optimum alternate reductant flowsheet for the Defense Waste Processing Facility (DWPF). Specifically, two proposed flowsheets (nitric-formic-glycolic and nitric-formic-sugar) were evaluated based upon results from preliminary testing. Comparison of the two flowsheets among evaluation criteria indicated a preference towards the nitric-formic-glycolic flowsheet. Further evaluation of this flowsheet eliminated the formic acid ${ }^{1}$, and as a result, the nitric-glycolic flowsheet was recommended for further testing.

Based on the development of a roadmap for the nitric-glycolic acid flowsheet, Waste Solidification Engineering (WS-E) issued a Technical Task Request (TTR) to address flammability issues that may impact the implementation of this flowsheet. Melter testing was requested in order to define the DWPF flammability envelope for the nitric glycolic acid flowsheet. The Savannah River National Laboratory (SRNL) Cold Cap Evaluation Furnace (CEF), a 1/12 ${ }^{\text {th }}$ scale DWPF melter, was selected by the SRR Alternate Reductant project team as the melter platform for this testing. The overall scope was divided into the following sub-tasks as discussed in the Task Technical and Quality Assurance Plan (TTQAP):

- Phase I - A nitric-formic acid flowsheet melter test (unbubbled) to baseline the Cold Cap Evaluation Furnace (CEF) cold cap and vapor space data to the benchmark melter flammability models

- $\quad$ Phase II - A nitric-glycolic acid flowsheet melter test (unbubbled and bubbled) to:

o Define new cold cap reactions and global kinetic parameters for the melter flammability models

o Quantify off-gas surging potential of the feed

o Characterize off-gas condensate for complete organic and inorganic carbon species

Prior to startup, a number of improvements and modifications were made to the CEF, including addition of cameras, vessel support temperature measurement, and a heating element near the pour tube. After charging the CEF with cullet from a previous Sludge Batch 6 (SB6) run, the melter was slurry-fed with SB6-Frit 418 melter feed at 36\% waste loading and was operated continuously for 6 days. Process data was collected throughout testing and included melter operation variables and off-gas chemistry. In order to satisfy the objective of Phase I testing, vapor space steady testing in the range of $\sim 300^{\circ} \mathrm{C}-700^{\circ} \mathrm{C}$ was conducted without argon bubbling to baseline the melter data to the existing DWPF melter flammability model. Adjustments to heater outputs, air flows and feed rate were necessary in order to achieve the vapor space temperatures in this range.

The results of the Phase I testing demonstrated that the CEF is capable of operating under the low vapor space temperatures A melter pressure of -5 inches of water was not sustained throughout the run, but the melter did remain slightly negative even with the maximum air flows required for the lowest temperature conditions were used. The auxiliary pour tube heater improved the pouring behavior at all test conditions, including reduced feed rates required for the low vapor space testing. Argon bubbling can be used to promote mixing and increase feed rate at multiple conditions. Improvements due to bubbling have been determined previously; however, the addition of the cameras to the CEF allows for visual observation during a range of bubbling configurations. The off-gas analysis system proved to be robust and capable of operating for long durations.

The total operational hours on the melter vessel are approximately 385 hours. Dimensional measurements taken prior to Phase I testing and support block temperatures recorded during Phase I testing are available if an extension of service life beyond 1250 hours is desired in the future. 


\section{TABLE OF CONTENTS}

LIST OF TABLES ix

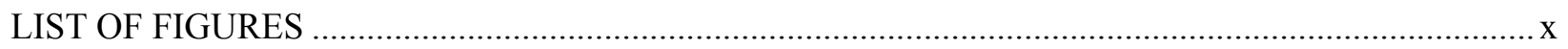

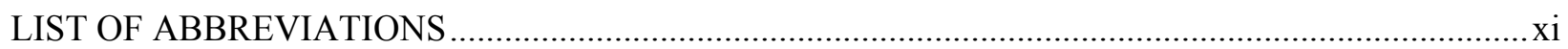

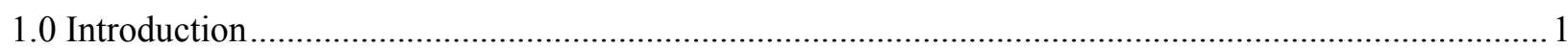

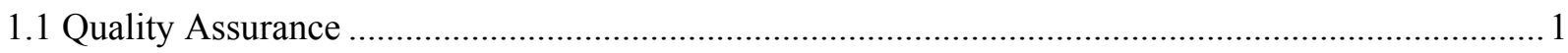

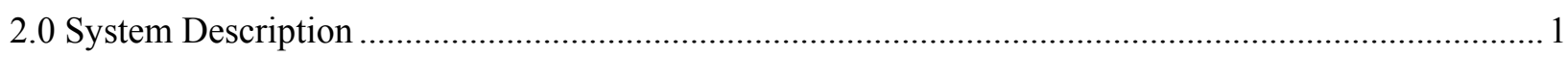

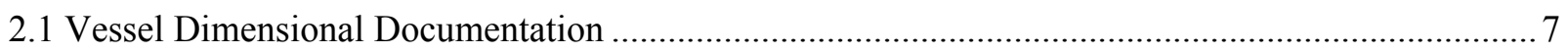

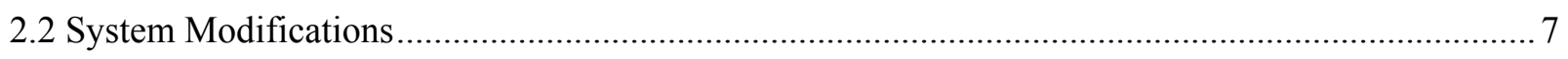

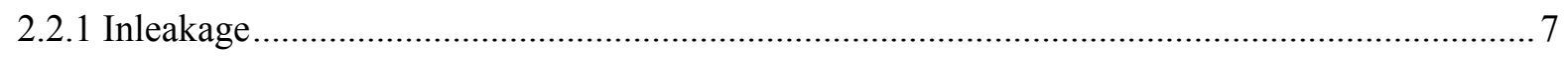

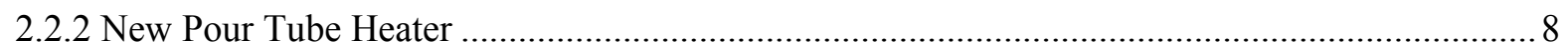

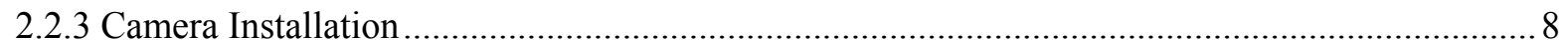

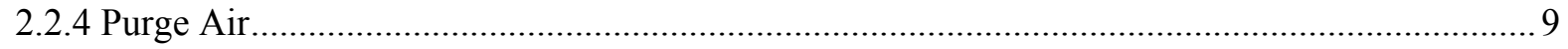

2.2.5 Off-gas Sampling System and Off-gas Instrumentation ................................................... 9

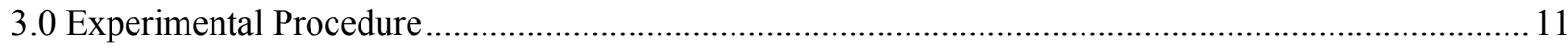

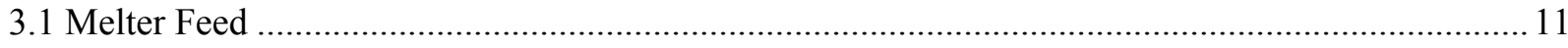

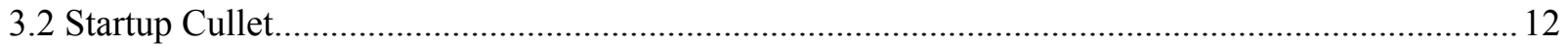

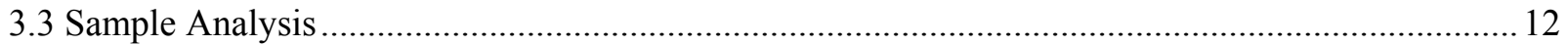

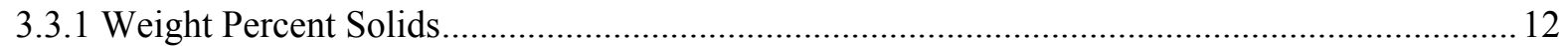

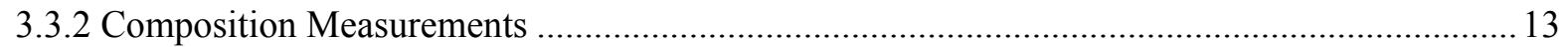

3.3.3 Glass Sample Reduction/Oxidation (REDOX) Measurements ............................................... 13

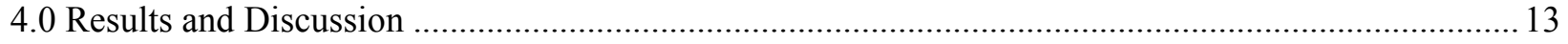

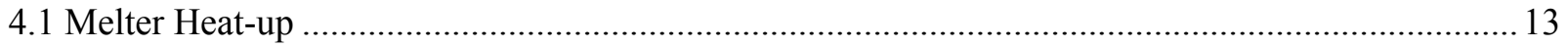

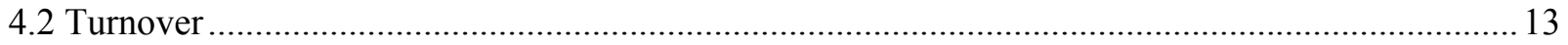

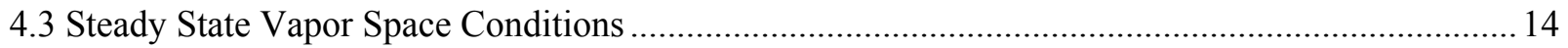

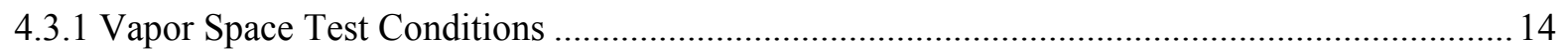

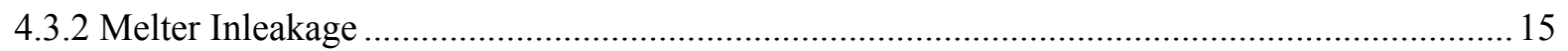

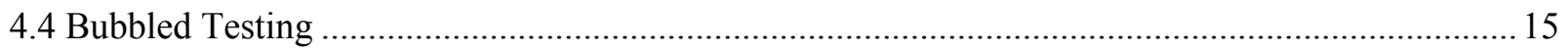

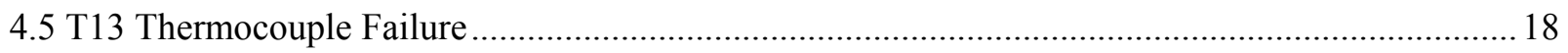

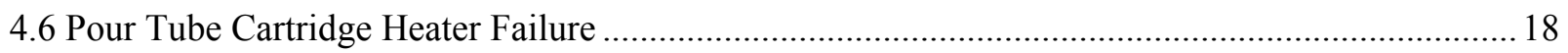

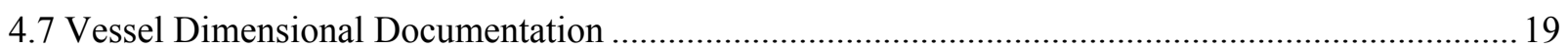

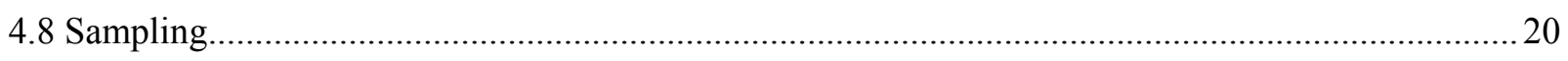

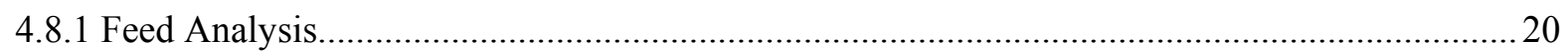




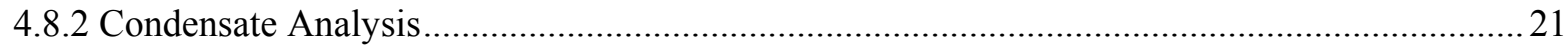

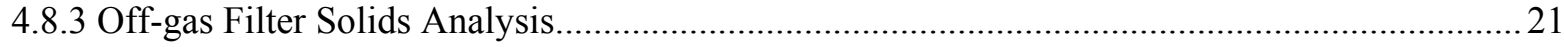

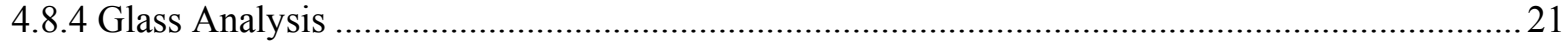

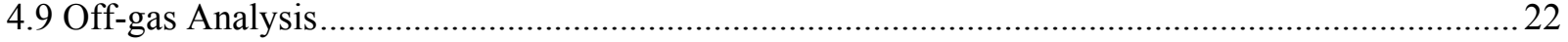

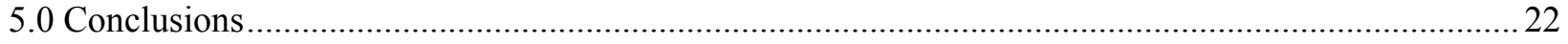

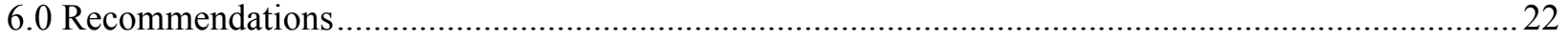

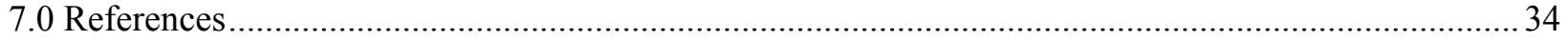

Appendix A . Supplementary Figures and Tables ........................................................................... 


\section{LIST OF TABLES}

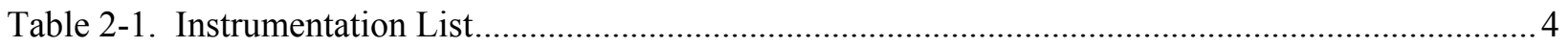

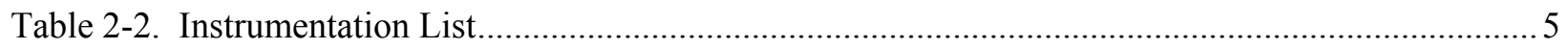

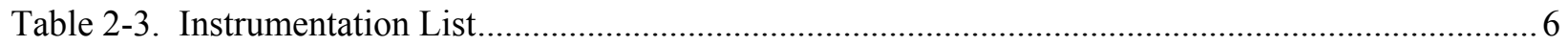

Table 3-1. Physical Properties of the Harrell SB6i SRAT Product ......................................................... 11

Table 3-2. Harrell SB6i SRAT and BlueGrass Chemical SB6i Simulant Compositions ......................... 12

Table 3-3. Harrell SB6i SRAT Product Supernate Composition $(\mathrm{mg} / \mathrm{L})$................................................. 12

Table 3-4. Harrell SB6i SRAT Product Anions and TOC (mg/kg) .................................................... 12

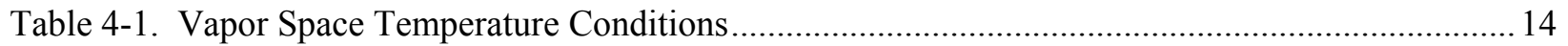

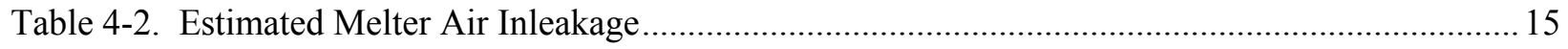

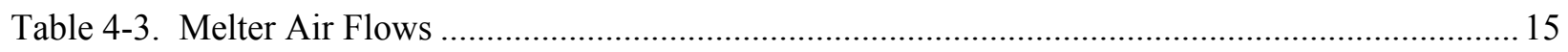

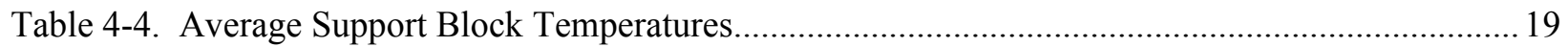

Table 4-5. Vapor Space Temperature Test Dates and Approximate Times.............................................21

Table 6-1. Measured Melter Feed Composition (wt $\%$ calcined at $\left.1100^{\circ} \mathrm{C}\right)$...........................................23

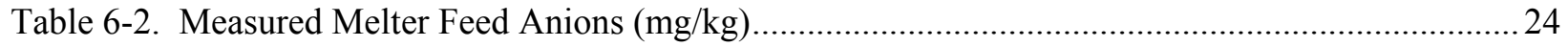

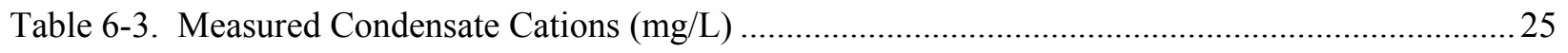

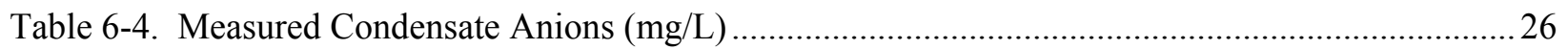

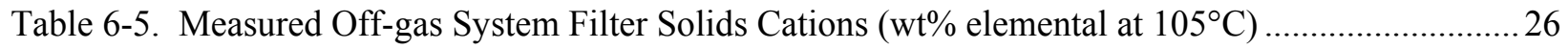

Table 6-6. Measured Off-gas System Filter Solids Anions (wt\%) ........................................................22

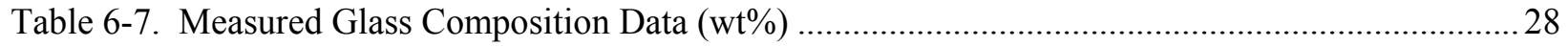

Table 6-8. Comparison of Calculated and Measured Compositions (wt\%)...........................................29

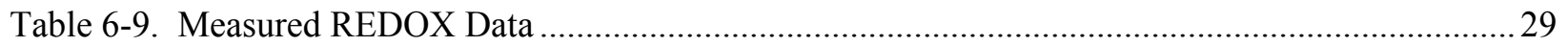




\section{LIST OF FIGURES}

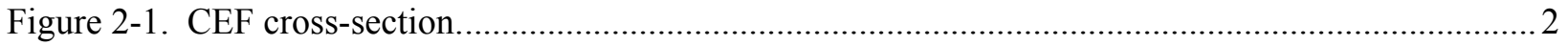

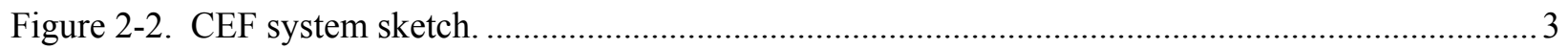

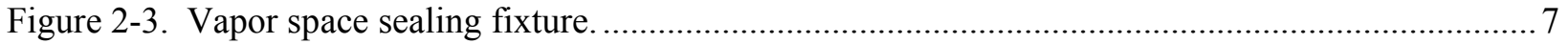

Figure 2-4. CEF cross section with close-up of cartridge heater and chimney ..................................... 8

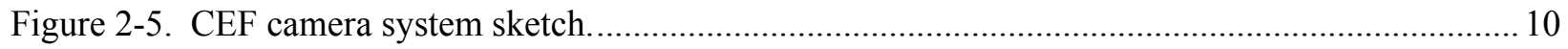

Figure 4-1. Images of CEF cold cap (vapor space target temperatures of $500-700^{\circ} \mathrm{C}$ )........................ 16

Figure 4-2. Images of CEF cold cap (vapor space target temperatures of $300-400^{\circ} \mathrm{C}$ )........................ 17

Figure 4-3. T13 thermocouple temperature as a function of time on May 29, 2013............................ 18

Figure 4-4. Pour tube heater output and temperature as a function of time prior to failure...................... 19

Figure 4-5. Support block temperatures throughout testing................................................................. 20

Figure 6-1. Hydrogen generation during bubbled and non-bubbled runs (Elapsed time $=0$ at 09:34 May 29,

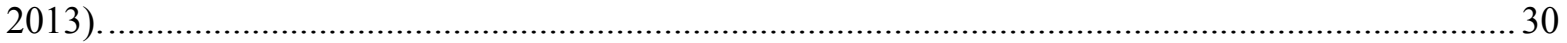

Figure 6-2. $\mathrm{CO}_{2}$ generation (Elapsed time $=0$ at 09:34 May 29, 2013) ............................................. 31

Figure 6-3. CO generation (Elapsed time $=0$ at 09:34 May 29, 2013) .................................................. 32

Figure 6-4. $\mathrm{NO}, \mathrm{NO}_{2}$ and $\mathrm{N}_{2} \mathrm{O}$ generation (Elapsed time $=0$ at 09:34 May 29, 2013).........................33 


\section{LIST OF ABBREVIATIONS}

\begin{tabular}{|c|c|}
\hline$\% \mathrm{RSD}$ & Relative Standard Deviation \\
\hline $\mathrm{AD}$ & Analytical Development \\
\hline ARP & Actinide Removal Process \\
\hline $\mathrm{CEF}$ & Cold Cap Evaluation Furnace \\
\hline DAS & Data Acquisition System (DAS) \\
\hline DVR & Digital Video Recorder \\
\hline DWPF & Defense Waste Processing Facility \\
\hline FTIR & Fourier Transform Infrared \\
\hline GC & Gas Chromatograph \\
\hline IC & Ion Chromatography \\
\hline ICP-AES & Inductively Coupled Plasma - Atomic Emission Spectroscopy \\
\hline inwc & Inches of Water Column \\
\hline MCU & Modular Caustic Side Solvent Extraction Unit \\
\hline MS & Mass Spectrometer \\
\hline OGCT & Off-gas Condensate Tank \\
\hline PSAL & Process Science Analytical Laboratory \\
\hline REDOX & REDuction/OXidation \\
\hline SB6 & Sludge Batch 6 \\
\hline scfm & Standard Cubic Feet per Minute \\
\hline SEE & Systems Engineering Evaluation \\
\hline SME & Slurry Mix Evaporator \\
\hline SRAT & Slurry Receipt and Adjustment Tank \\
\hline SRNL & Savannah River National Laboratory \\
\hline SRR & Savannah River Remediation \\
\hline TIC & Total Inorganic Carbon \\
\hline TOC & Total Organic Carbon \\
\hline TTQAP & Task Technical and Quality Assurance Plan \\
\hline TTR & Technical Task Request \\
\hline UV-Vis & Ultraviolet-visible \\
\hline WSE & Waste Solidification Engineering \\
\hline
\end{tabular}




\subsection{Introduction}

Savannah River Remediation (SRR) conducted a Systems Engineering Evaluation (SEE) ${ }^{2}$ to determine the optimum alternate reductant flowsheet for the Defense Waste Processing Facility (DWPF). Specifically, two proposed flowsheets (nitric-formic-glycolic and nitric-formic-sugar) were evaluated based upon results from preliminary testing. ${ }^{3,4}$ Comparison of the two flowsheets among evaluation criteria indicated a preference towards the nitric-formic-glycolic flowsheet. Further evaluation of this flowsheet eliminated the formic acid ${ }^{1}$, and as a result, the nitric-glycolic flowsheet was recommended for further testing.

Based on the development of a roadmap for the nitric-glycolic acid flowsheet ${ }^{5}$, Waste Solidification Engineering (WS-E) issued a Technical Task Request ${ }^{6}$ (TTR) to address flammability issues that may impact the implementation of this flowsheet. Melter testing was requested in order to define the DWPF flammability envelope for the nitric glycolic acid flowsheet. The overall scope was divided into the following sub-tasks as discussed in the Task Technical and Quality Assurance Plan (TTQAP) ${ }^{7}$ :

- Phase I - A nitric-formic acid flowsheet melter test (unbubbled) to baseline the Cold Cap Evaluation Furnace (CEF) cold cap and vapor space data to the benchmark melter flammability models over a series of vapor space temperatures

- Phase II - A nitric-glycolic acid flowsheet melter test (unbubbled and bubbled) to:

o Define new cold cap reactions and global kinetic parameters for the melter flammability models

o Quantify off-gas surging potential of the feed

o Characterize off-gas condensate for complete organic and inorganic carbon species

The Savannah River National Laboratory (SRNL) CEF, a $1 / 12^{\text {th }}$ scale DWPF melter, was selected by the SRR Alternate Reductant project team as the melter platform for this testing. ${ }^{8}$ Both the CEF and DWPF melter have cylindrical cavities of the same or nearly the same diameter from the top to bottom and, therefore, their vapor space-to-melt pool cross-sectional area ratios are approximately 1.8. The melt pool aspect ratio of the CEF, which is defined as the melt pool diameter-to-melt pool depth, is also practically identical to that of the DWPF melter; however, the vapor space aspect ratio of the CEF was designed at $1 / 2$ of the DWPF melter in an effort to reduce off-gas carryover under bubbled conditions.

The intent of this report is to provide a description of the system in its present state, operating conditions throughout testing and a compilation of sample data for Phase I testing only. It should be noted that the interpretation and discussion of operating data and sample data will be limited. A detailed analysis of the off-gas chemistry and the flammability model assessment will be addressed separately. ${ }^{9}$ Phase II testing will be discussed in a subsequent report.

\subsection{Quality Assurance}

Requirements for performing reviews of technical reports and the extent of review are established in manual E7 2.60. SRNL documents the extent and type of review using the SRNL Technical Report Design Checklist contained in WSRC-IM-2002-00011, Rev. 2.

\subsection{System Description}

The CEF is a 30 inch tall, 20 inch diameter Inconel ${ }^{\circledR} 690$ vessel that was fabricated at SRNL to conduct observations of cold cap behavior under a variety of melter conditions. ${ }^{10-26}$ The unit consists of 5 heating zones that are controlled separately. ${ }^{27}$ The heaters are spiral wound silicon carbide resistance heater elements that provide heat externally to the vessel. Four vapor space heaters are located inside the vessel and are surrounded by alumina tubes to protect them from the environment. A section view of the CEF is 
shown in Figure 2-1. The melter was installed in the Engineering Development Laboratory (786-A) along with the off-gas system, which was similar to the system used in previous runs. The new configuration uses a blower to exhaust the gasses from the off-gas condensate tank (OGCT) to atmosphere. In the previous configuration the OGCT vented into a walk-in hood. A schematic of the entire system is shown in Figure 2-2. The melter is operated under a slight negative pressure (nominally -5 inches of water [inwc]), which captures the volatile components through a quencher/scrubber system. An instrumentation list for the entire system is shown in Table 2-1 through Table 2-3.

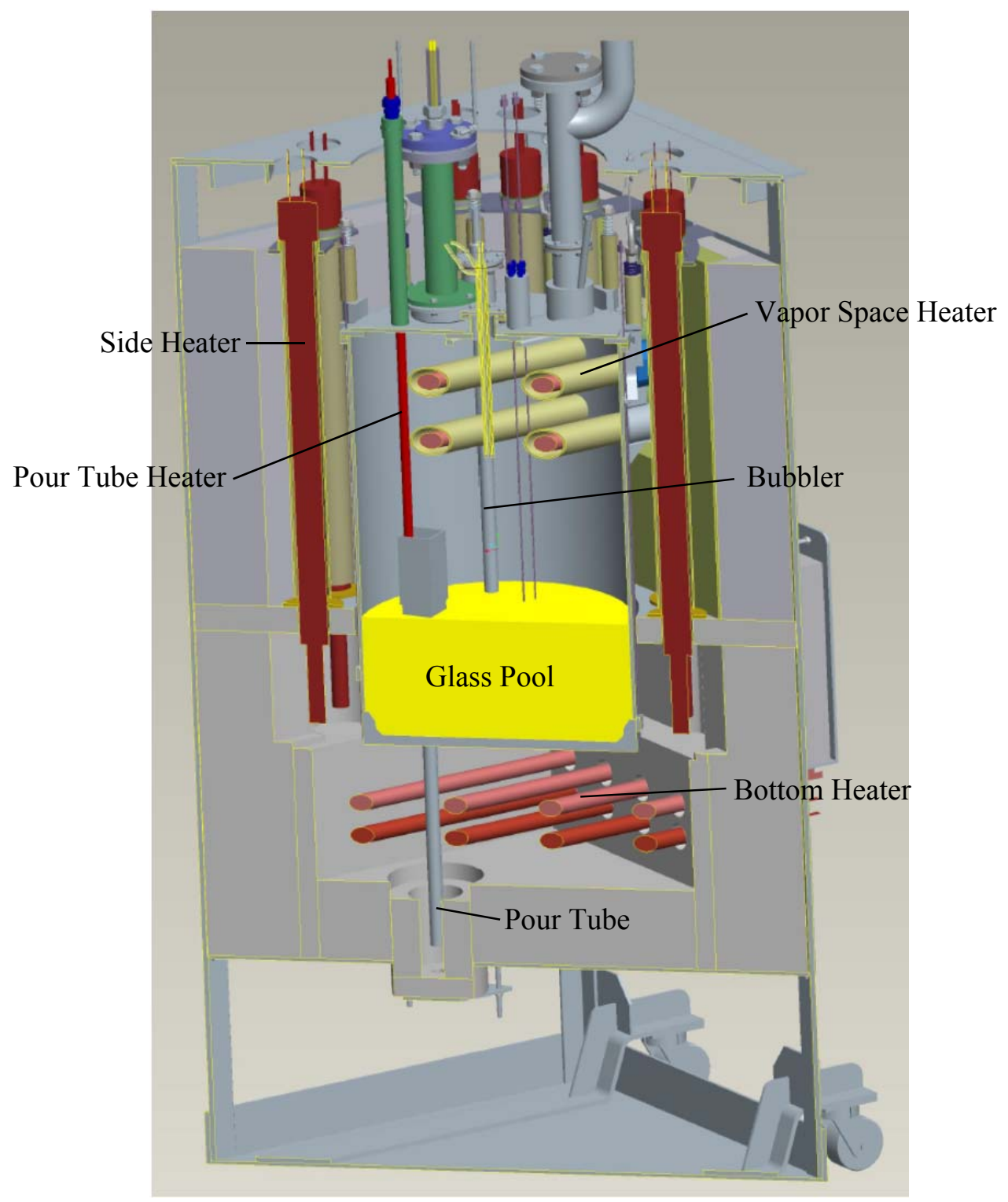

Figure 2-1. CEF cross-section. 


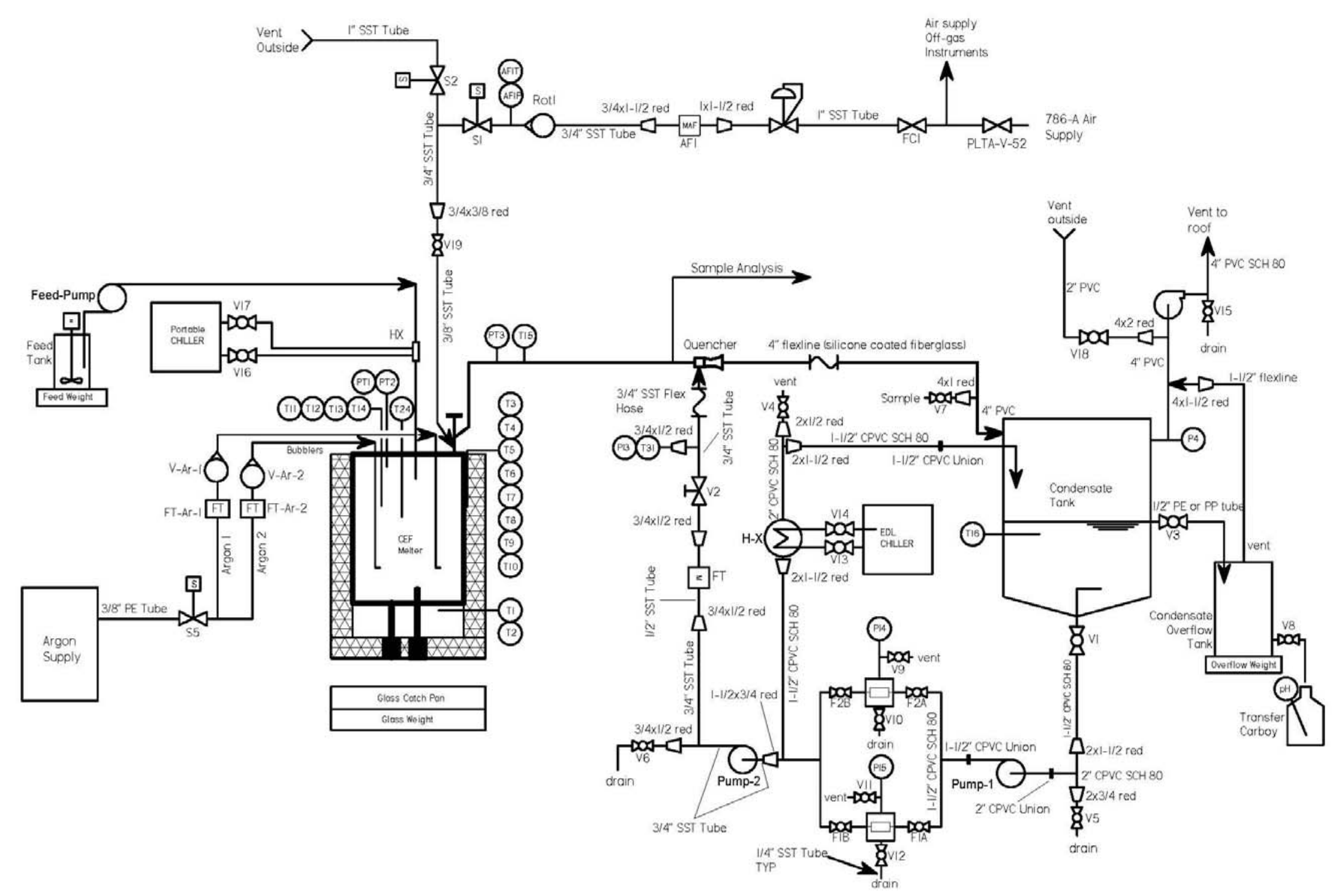

Figure 2-2. CEF system sketch. 
Table 2-1. Instrumentation List ${ }^{\mathrm{a}}$

\begin{tabular}{|c|c|c|c|c|c|}
\hline System & Designation & Des cription & Range & Tolerance & Electronic \\
\hline Melter & PT1 & Melter vapor space pressure 1 , & -20 to +20 in $\mathrm{H} 2 \mathrm{O}$ & $+/-0.5 \% \mathrm{fs}$ & $4-20 \mathrm{~mA}$ \\
\hline Melter & PT2 & Melter vapor space pressure 2 & -20 to +20 in $\mathrm{H} 2 \mathrm{O}$ & $+/-0.5 \%$ fs & $4-20 \mathrm{~mA}$ \\
\hline Melter & V-Ar-1 & Bubbler 1 argon flow, rotameter & $0-0.7 \mathrm{scfm}$ & manuf. spec. & N/A \\
\hline Melter & FT-Ar-1 & Bubbler 1 mass flow controller & $0-0.75 \mathrm{scfm}$ & $+/-(0.5 \% \mathrm{rdg}+4 \% \mathrm{fs})$ & $4-20 \mathrm{~mA}$ \\
\hline Melter & V-Ar-2 & Bubbler 2 argon flow, rotameter & $0-0.7 \mathrm{scfm}$ & manuf. spec. & N/A \\
\hline Melter & FT-Ar-2 & Bubbler 2 mass flow controller & $0-0.75 \mathrm{scfm}$ & $+/-(0.5 \% \mathrm{rdg}+1.5 \% \mathrm{fs})$ & $4-20 \mathrm{~mA}$ \\
\hline Melter & T1a & Vessel bottom 1, type K T/C & -200 to $1250^{\circ} \mathrm{C}$ & $+/-2.2^{\circ} \mathrm{C}$ & -5.9 to $50.6 \mathrm{mV}$ \\
\hline Melter & $\mathrm{T} 1 \mathrm{~b}$ & Vessel bottom 1 , type $\mathrm{K} \mathrm{T/C}$, spare & -200 to $1250^{\circ} \mathrm{C}$ & $+/-2.2^{\circ} \mathrm{C}$ & -5.9 to $50.6 \mathrm{mV}$ \\
\hline Melter & $\mathrm{T} 2 \mathrm{a}$ & Vessel bottom 2, type K T/C & -200 to $1250^{\circ} \mathrm{C}$ & $+/-2.2^{\circ} \mathrm{C}$ & -5.9 to $50.6 \mathrm{mV}$ \\
\hline Melter & $\mathrm{T} 2 \mathrm{~b}$ & Vessel bottom 2 , type $\mathrm{K} \mathrm{T/C}$, spare & -200 to $1250^{\circ} \mathrm{C}$ & $+/-2.2^{\circ} \mathrm{C}$ & -5.9 to $50.6 \mathrm{mV}$ \\
\hline Melter & $\mathrm{T} 3$ & Vessel side elev. 1A, type K T/C & -200 to $1250^{\circ} \mathrm{C}$ & $+/-2.2^{\circ} \mathrm{C}$ & -5.9 to $50.6 \mathrm{mV}$ \\
\hline Melter & $\mathrm{T} 4$ & Vessel side elev. 1B, type K T/C & -200 to $1250^{\circ} \mathrm{C}$ & $+/-2.2^{\circ} \mathrm{C}$ & -5.9 to $50.6 \mathrm{mV}$ \\
\hline Melter & $\mathrm{T} 5$ & Vessel side elev. 2A, type K T/C & -200 to $1250^{\circ} \mathrm{C}$ & $+/-2.2^{\circ} \mathrm{C}$ & -5.9 to $50.6 \mathrm{mV}$ \\
\hline Melter & T6 & Vessel side elev. 2B, type K T/C & -200 to $1250^{\circ} \mathrm{C}$ & $+/-2.2^{\circ} \mathrm{C}$ & -5.9 to $50.6 \mathrm{mV}$ \\
\hline Melter & $\mathrm{T} 7$ & Vessel side elev. 3A, type K T/C & -200 to $1250^{\circ} \mathrm{C}$ & $+/-2.2^{\circ} \mathrm{C}$ & -5.9 to $50.6 \mathrm{mV}$ \\
\hline Melter & $\mathrm{T} 8$ & Vessel side elev. 3B, type K T/C & -200 to $1250^{\circ} \mathrm{C}$ & $+/-2.2^{\circ} \mathrm{C}$ & -5.9 to $50.6 \mathrm{mV}$ \\
\hline Melter & T9 & Vessel side elev. 4A, type K T/C & -200 to $1250^{\circ} \mathrm{C}$ & $+/-2.2^{\circ} \mathrm{C}$ & -5.9 to $50.6 \mathrm{mV}$ \\
\hline Melter & T10 & Vessel side elev. 4B, type K T/C & -200 to $1250^{\circ} \mathrm{C}$ & $+/-2.2^{\circ} \mathrm{C}$ & -5.9 to $50.6 \mathrm{mV}$ \\
\hline Melter & T11 & Vapor space 1 , type K T/C & -200 to $1250^{\circ} \mathrm{C}$ & $+/-2.2^{\circ} \mathrm{C}$ & -5.9 to $50.6 \mathrm{mV}$ \\
\hline Melter & T12 & Vapor space 2 , type K T/C & -200 to $1250^{\circ} \mathrm{C}$ & $+/-2.2^{\circ} \mathrm{C}$ & -5.9 to $50.6 \mathrm{mV}$ \\
\hline Melter & $\mathrm{T} 13$ & Glass pool 1, type K T/C & -200 to $1250^{\circ} \mathrm{C}$ & $+/-2.2^{\circ} \mathrm{C}$ & -5.9 to $50.6 \mathrm{mV}$ \\
\hline Melter & $\mathrm{T} 14$ & Glass pool 2, type K T/C & -200 to $1250^{\circ} \mathrm{C}$ & $+/-2.2^{\circ} \mathrm{C}$ & -5.9 to $50.6 \mathrm{mV}$ \\
\hline Melter & $\mathrm{T} 24$ & Pour tube heater, type K T/C & -200 to $1250^{\circ} \mathrm{C}$ & $+/-2.2^{\circ} \mathrm{C}$ & -5.9 to $50.6 \mathrm{mV}$ \\
\hline Melter & $\mathrm{T} 25$ & Rod Support 1, type K T/C & -200 to $1250^{\circ} \mathrm{C}$ & $+/-2.2^{\circ} \mathrm{C}$ & -5.9 to $50.6 \mathrm{mV}$ \\
\hline Melter & $\mathrm{T} 26$ & Rod Support 2, type K T/C & -200 to $1250^{\circ} \mathrm{C}$ & $+/-2.2^{\circ} \mathrm{C}$ & -5.9 to $50.6 \mathrm{mV}$ \\
\hline Melter & $\mathrm{T} 27$ & Rod Support 3, type K T/C & -200 to $1250^{\circ} \mathrm{C}$ & $+/-2.2^{\circ} \mathrm{C}$ & -5.9 to $50.6 \mathrm{mV}$ \\
\hline Melter & $\mathrm{T} 28$ & Rod Support 4, type K T/C & -200 to $1250^{\circ} \mathrm{C}$ & $+/-2.2^{\circ} \mathrm{C}$ & -5.9 to $50.6 \mathrm{mV}$ \\
\hline Melter & T29 & Rod Support 5, type K T/C & -200 to $1250^{\circ} \mathrm{C}$ & $+/-2.2^{\circ} \mathrm{C}$ & -5.9 to $50.6 \mathrm{mV}$ \\
\hline
\end{tabular}

${ }^{\mathrm{a}}$ Inches of water (in $\left.\mathrm{H} 2 \mathrm{O}\right)$, percent of full scale (\%fs), milliamps (mA), standard cubic feet per meter (scfm), percent of reading $(\%$ rdg), thermocouple (T/C) and millivolts (mV). 
Table 2-2. Instrumentation List ${ }^{\mathrm{b}}$

\begin{tabular}{|c|c|c|c|c|c|}
\hline System & Designation & Description & Range & Tolerance & Electronic \\
\hline Melter & $\mathrm{T} 30$ & Rod Support 6, type K T/C & -200 to $1250^{\circ} \mathrm{C}$ & $+/-2.2^{\circ} \mathrm{C}$ & -5.9 to $50.6 \mathrm{mV}$ \\
\hline Melter & Glass Weight & Poured glass container platform & $0-30 \mathrm{Kg}$ & $+/-0.75 \%$ rdg & --- \\
\hline Off-Gas & PT3 & Off-gas pressure transmitter & -20 to +20 in $\mathrm{H} 2 \mathrm{O}$ & $+/-0.5 \%$ fs & $4-20 \mathrm{~mA}$ \\
\hline Off-Gas & T15 & Off-gas, type K T/C & -200 to $1250^{\circ} \mathrm{C}$ & $+/-2.2^{\circ} \mathrm{C}$ & --- \\
\hline Condensate & P1 & Quencher condensate inlet & 0 to $180 \mathrm{psig}$ & manuf. spec. & --- \\
\hline Condensate & FT & Quencher condensate inlet flow & 0 to $15 \mathrm{gpm}$ & $+/-0.2 \mathrm{gpm}$ & $4-20 \mathrm{~mA}$ \\
\hline Condensate & $\mathrm{pH}$ & Condensate overflow $\mathrm{pH}$ & manuf. spec. & manuf. spec. & $\mathrm{N} / \mathrm{A}$ \\
\hline Condensate & Overflow Weight & Condensate overflow vessel & $0-30 \mathrm{Kg}$ & $+/-0.75 \%$ rdg & --- \\
\hline Condensate & T31 & Quencher condensate inlet, type $\mathrm{K}$ & -200 to $1250^{\circ} \mathrm{C}$ & $+/-2.2^{\circ} \mathrm{C}$ & -5.9 to $50.6 \mathrm{mV}$ \\
\hline Condensate & PI4 & Condensate filter housing 1 & 0 to $30 \mathrm{psig}$ & manuf. spec. & N/A \\
\hline Condensate & PI5 & Condensate filter housing 2 & 0 to $30 \mathrm{psig}$ & manuf. spec. & N/A \\
\hline Condensate & T16 & Condensate Tank temperature, & -200 to $1250^{\circ} \mathrm{C}$ & manuf. spec. & -5.9 to $50.6 \mathrm{mV}$ \\
\hline Feed & Feed Weight & Melter feed vessel platform scale & $0-30 \mathrm{Kg}$ & $+/-0.75 \% \mathrm{rdg}$ & --- \\
\hline Air Supply & Rot1 & Film cooler air flow, rotameter & $0-25 \mathrm{scfm}$ & $+/-(0.5 \% \mathrm{rdg}+3 \% \mathrm{fs})$ & $\mathrm{N} / \mathrm{A}$ \\
\hline Air Supply & AF1 & $\begin{array}{l}\text { Film cooler air flow, mass flow } \\
\text { meter }\end{array}$ & $0-25 \mathrm{scfm}$ & $+/-(0.5 \% \mathrm{rdg}+2.5 \% \mathrm{fs})$ & $4-20 \mathrm{~mA}$ \\
\hline Air Supply & AF1T & Rotameter 1 temperature, type $\mathrm{K}$ & -200 to $1250{ }^{\circ} \mathrm{C}$ & $+/-2.2^{\circ} \mathrm{C}$ & -5.9 to $50.6 \mathrm{mV}$ \\
\hline Air Supply & AF1P & Rotameter 1 pressure, pressure & $0-100$ psig & manuf. spec. & $\mathrm{N} / \mathrm{A}$ \\
\hline Air Supply & Rot2 & Camera 1 (Canty) air flow, & $0-25 \mathrm{scfm}$ & $+/-(0.5 \% \mathrm{rdg}+3 \% \mathrm{fs})$ & N/A \\
\hline Air Supply & AF2 & Camera 1 (Canty) air flow, mass & $0-150 \mathrm{scfm}$ & $+/-(0.5 \% \mathrm{rdg}+2 \% \mathrm{fs})$ & $4-20 \mathrm{~mA}$ \\
\hline Air Supply & AF2T & Rotameter 2 temperature, type $\mathrm{K}$ & -200 to $1250^{\circ} \mathrm{C}$ & $+/-2.2^{\circ} \mathrm{C}$ & -5.9 to $50.6 \mathrm{mV}$ \\
\hline Air Supply & AF2P & Rotameter 2 pressure, pressure & $0-60$ psig & manuf. spec. & N/A \\
\hline Air Supply & Rot3 & Camera 2 (JG) inlet air flow, & $0-25 \mathrm{scfm}$ & $+/-(0.5 \% \mathrm{rdg}+3 \% \mathrm{fs})$ & N/A \\
\hline Air Supply & AF3 & Camera 2 (JG) inlet air flow, mass & $0-25 \mathrm{scfm}$ & $+/-(1 \% \mathrm{rdg}+5 \% \mathrm{fs})$ & $4-20 \mathrm{~mA}$ \\
\hline Air Supply & AF3T & Rotameter 3 temperature, type $\mathrm{K}$ & -200 to $1250^{\circ} \mathrm{C}$ & $+/-2.2^{\circ} \mathrm{C}$ & -5.9 to $50.6 \mathrm{mV}$ \\
\hline Air Supply & AF3P & Rotameter 3 pressure, pressure & $0-100$ psig & manuf. spec. & N/A \\
\hline Air Supply & Rot4 & Camera 2 (JG) outlet air flow, & $0-25 \mathrm{scfm}$ & $+/-(0.5 \% \mathrm{rdg}+3 \% \mathrm{fs})$ & N/A \\
\hline Air Supply & AF4 & Camera 2 (JG) outlet air flow, mass & $0-25 \mathrm{scfm}$ & $+/-(1 \% \mathrm{rdg}+1 \% \mathrm{fs})$ & $4-20 \mathrm{~mA}$ \\
\hline Air Supply & AF4T & Rotameter 4 temperature, type K & -200 to $1250^{\circ} \mathrm{C}$ & $+/-2.2^{\circ} \mathrm{C}$ & -5.9 to $50.6 \mathrm{mV}$ \\
\hline
\end{tabular}

\footnotetext{
${ }^{b}$ Inches of water (in $\left.\mathrm{H} 2 \mathrm{O}\right)$, percent of full scale (\%fs), milliamps (mA), standard cubic feet per meter (scfm), percent of reading (\%rdg), thermocouple (T/C), millivolts (mV),
} pounds per square inch gauge (psig) and gallons per minute $(\mathrm{gpm})$. 
Table 2-3. Instrumentation List ${ }^{\mathrm{c}}$

\begin{tabular}{|c|c|c|c|c|c|}
\hline System & Designation & Des cription & Range & Tolerance & Electronic \\
\hline Air Supply & AF4P & Rotameter 4 pressure, pressure & $0-60 \mathrm{psig}$ & manuf. spec. & $\mathrm{N} / \mathrm{A}$ \\
\hline Air Supply & Rot5 & Melter stoke air flow, rotameter & $0-15 \mathrm{scfm}$ & $+/-(1 \% \mathrm{rdg}+4 \% \mathrm{fs})$ & N/A \\
\hline Air Supply & AF5T & Rotameter 5 temperature, type $\mathrm{K}$ & -200 to $1250^{\circ} \mathrm{C}$ & $+/-2.2^{\circ} \mathrm{C}$ & -5.9 to $50.6 \mathrm{mV}$ \\
\hline Air Supply & AF5P & Rotameter 5 pressure, pressure & $0-100$ psig & manuf. spec. & N/A \\
\hline System & Designation & Description & Voltage & Function & Body \\
\hline Solenoids & $\mathrm{S} 1$ & Film cooler air shutoff & 110 & $\mathrm{NC}$ & brass \\
\hline Solenoids & $\mathrm{S} 2$ & Film cooler air vent & 110 & NO & brass \\
\hline Solenoids & S3 & Canty camera shutoff & 110 & NO & brass \\
\hline Solenoids & S4 & Melter stoke air shutoff & 110 & $\mathrm{NC}$ & SST \\
\hline Solenoids & S5 & Argon bubblers shutoff & 110 & $\mathrm{NC}$ & - \\
\hline
\end{tabular}

${ }^{\mathrm{c}}$ Pounds per square inch gauge (psig), standard cubic feet per minute ( $\left.\mathrm{scfm}\right)$, percent of reading (\%rdg), percent of full scale (\%fs), millivolt (mV), normally closed (NC), normally open (NO), stainless steel (SST). 


\subsection{Vessel Dimensional Documentation}

Since the Inconel ${ }^{\circledR} 690$ vessel is operated at elevated temperature, structural creep has always been a concern, especially since the vessel is suspended. After the top of the melter was removed, measurements indicated that the vessel had not undergone major dimensional changes during the previous cycles. ${ }^{28}$ The original melter service life was set at 500 hours; however, due to the alternate reductant test durations, a service life beyond 500 hours was desired. W. Daugherty conducted a creep life assessment of the Inconel ${ }^{\circledR} 690$ melter vessel based on a reduced temperature at the lug areas and estimated that the service life could be extended to 1250 hours. ${ }^{\mathrm{d}, 29}$ It was also recommended that periodic measurements of vessel dimensions should be performed to track actual creep strain so that there would be a basis for additional increases in service life.

An additional calculation related specifically to the tension rods from which the melter is suspended indicated that the total life of the tension rods should be limited to 1250 hours, which is consistent with the creep life calculation by Daugherty for the vessel. ${ }^{30}$ Tension rod length measurements and temperature monitoring were recommended as requirements for continued operation of the melter. As a result, thermocouples were welded onto the support blocks of the vessel to gather information for use in future creep and melter life calculations.

\subsection{System Modifications}

Based on previous tests involving the CEF, several modifications were made to improve the performance of the melter system.

\subsubsection{Inleakage}

To reduce air inleakage into the vessel, the top was removed and the sealing areas were resurfaced. In addition, a new thicker gasket was added between the top and the vessel flange. A fixture was designed and fabricated that provided a packing gland seal to be installed on the vapor space heaters tubes. Both the vessel nozzles and alumina tubes had seals provided using a high temperature gasket material. The double gasket seals are shown in black in Figure 2-3.

Testing prior to heat-up indicated that the melter air inleakage had been reduced from previous campaigns. Vacuum testing identified several sources of leaks that were reduced through tightening and replacement of connections. Argon was used as a tracer gas along with the mass spectrometer to measure inleakage over a range of quencher flows.

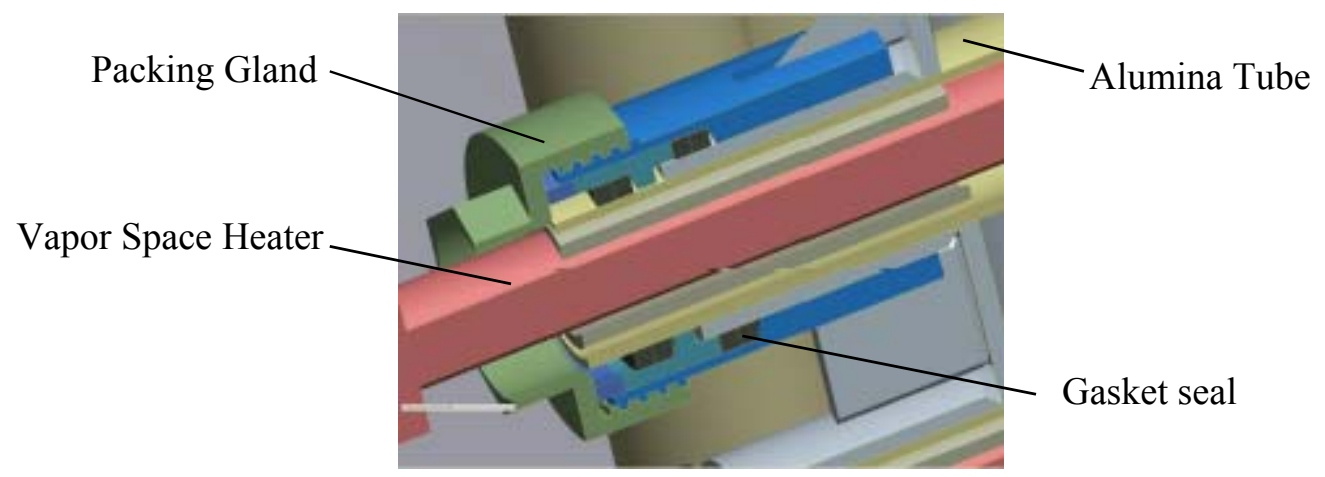

Figure 2-3. Vapor space sealing fixture.

\footnotetext{
${ }^{\mathrm{d}}$ At the time the report was issued, the vessel had been operated $\sim 250$ hours. It was estimated that decreasing the temperature of the lug areas from $1125^{\circ} \mathrm{C}$ to $1050^{\circ} \mathrm{C}$ would increase the remaining service life from 250 hours to approximately 2500 hours; however, operation was limited to an additional 1000 hours to account for uncertainties in the analysis.
} 


\subsubsection{New Pour Tube Heater}

Previous testing with the CEF had indicated that some locations in the melt pool were more than $\sim 100^{\circ} \mathrm{C}$ lower than the control temperature. Since Phase I testing would involve reduced vapor space temperatures, it was decided to add an auxiliary heater to the melt pool in order to increase melt pool temperature and reduce the glass viscosity near the pour tube for improved pouring. An Inconel ${ }^{\circledR}$ sheathed cartridge heater was installed inside the chimney surrounding the pour tube (Figure 2-4).

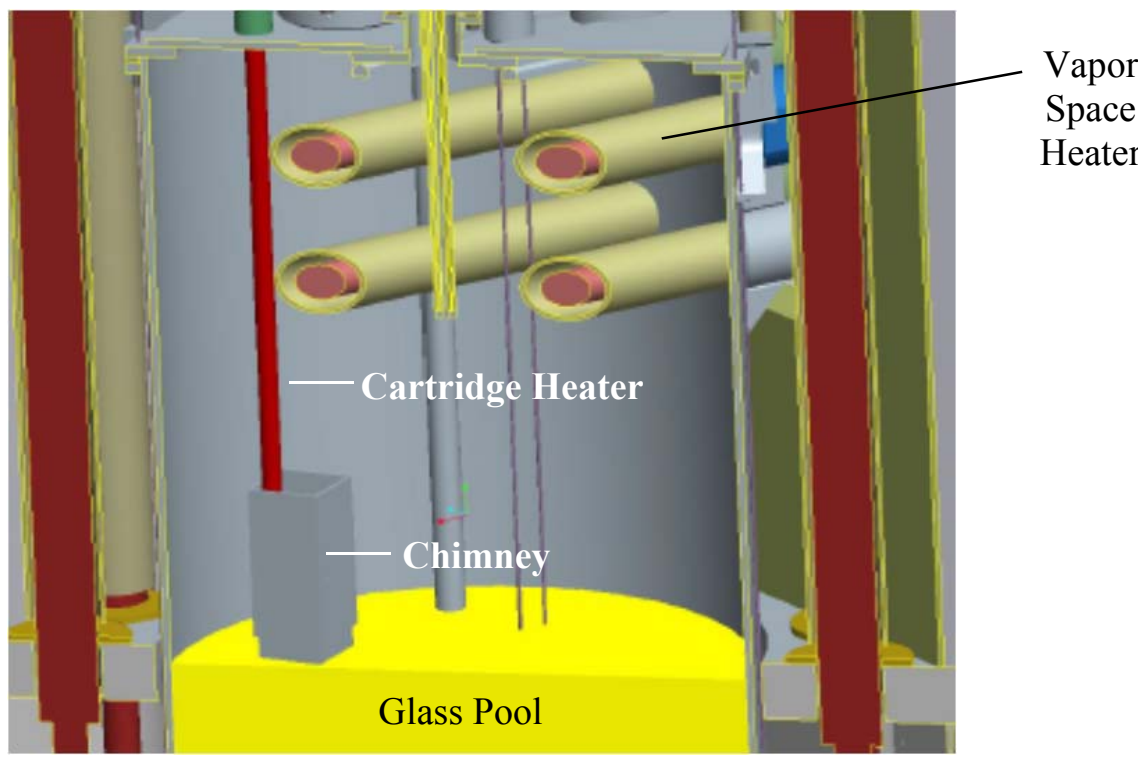

Figure 2-4. CEF cross section with close-up of cartridge heater and chimney.

Since conditions in the CEF are atypical for this type of heater it was desired to perform an assessment of the heater prior to actual testing, which would simulate conditions experienced in the melter. Small scale testing of a similar cartridge heater using a laboratory scale furnace and a platinum alloy crucible filled with glass indicated that the heater would potentially remain operational during the Phase I test conditions. e $^{\mathrm{e}}$

\subsubsection{Camera Installation}

Two new cameras were installed on the CEF to provide better views of the cold cap surface during operation. The camera system in detail is shown in Figure 2-5. ${ }^{\mathrm{f}}$ An air cooled high temperature camera supplied by J.M. Canty, Inc. was installed in a vessel top opening previously used as a sight port. ${ }^{\mathrm{g}}$ The camera specifications are as follows:

- System video format - U.S. Color

- Power Supply - $120 \mathrm{~V}$ and $60 \mathrm{~Hz}$ Input

- System diameter -2.875 inches

- System view angle $-42^{\circ} \mathrm{H} \times 32^{\circ} \mathrm{V}$

- Optical shield - clear quartz

- Material of construction for shell - 304L stainless steel

\footnotetext{
${ }^{\mathrm{e}}$ The furnace temperature was held at approximately $735^{\circ} \mathrm{C}$ for 19 days to simulate temperatures experienced in the melter vapor space. The cartridge heater was used to maintain a temperature of approximately $1120^{\circ} \mathrm{C}$ in the glass. In general, heater operation was limited to daytime operation only ( $\sim 9$ hours per day), with the exception of 3 days of continuous operation.

${ }^{\mathrm{f}}$ Camera 1 refers to the J.M. Canty, Inc. high temperature camera and Camera 2 refers to the camera designed at SRNL.

${ }^{\mathrm{g}}$ Canty MINITEMP ${ }^{\mathrm{TM}}$ High Temperature Camera, Part Number: MHT-B1S2A1A
} 
- Cooling requirements -8 standard cubic feet minute $(\mathrm{scfm})$ of air or nitrogen

A high temperature camera designed by SRNL specifically for this system ${ }^{\mathrm{h}}$ was also installed in a modified top port to provide a second view of the cold cap surface. ${ }^{31-35}$ The cameras were connected to a monitor so that the cold cap could be viewed in real time and a digital video recorder (DVR) to save the video during testing.

\subsubsection{Purge Air}

In order to establish lower vapor space temperatures and ensure adequate combustion, a separate purge line was added to supply a variable amount of air as needed during testing. This purge air was in addition to the cooling air provided for the cameras (up to $13 \mathrm{scfm}$ for the J.M. Canty, Inc. camera and approximately $1 \mathrm{scfm}$ for the SRNL camera ${ }^{\mathrm{i}}$ ).

\subsubsection{Off-gas Sampling System and Off-gas Instrumentation}

Offgas sampling was performed using a gas sampling system connected to a process mass spectrometer (MS) (Extrel CMS model MAX300-LG), a process Fourier Transform Infrared (FTIR) spectrometer (MKS model MG-2030) and a gas chromatograph (GC) (Agilent Micro Gas Chromatograph). A backup mass spectrometer (Monitor Instruments) was also available for use, but was not used.

The gas sampling system consisted of two parallel coalescing filters to remove particulates and condensable water; the parallel arrangement was used so that one filter could be taken offline and changed. Redundant gas sampling diaphragm pumps were used in parallel so that an installed spare was always available. The gas sample was extracted from the melter off-gas system between the film cooler and the quencher at a rate of 1-6 L/min. The gas sample was conditioned using a PermaPure MiniGASS sample conditioner that consisted of an additional coalescing filter and a Nafion dryer to remove water to a dew point of less than $0^{\circ} \mathrm{C}$ (typically less than $-10^{\circ} \mathrm{C}$ ).

The mass spectrometer was calibrated to measure $\mathrm{H}_{2}, \mathrm{O}_{2}, \mathrm{~N}_{2}, \mathrm{NO}, \mathrm{NO}_{2}, \mathrm{Ar}, \mathrm{CO}_{2}$, and $\mathrm{SO}_{2} . \mathrm{N}_{2} \mathrm{O}$ could not be measured by MS and its presence causes the measured concentrations of $\mathrm{CO}_{2}, \mathrm{NO}$, and $\mathrm{N}_{2}$ to be slightly higher than the actual values because $\mathrm{N}_{2} \mathrm{O}$ has mass-to-charge $(\mathrm{m} / \mathrm{z})$ fragments with the same mass as $\mathrm{CO}_{2}$ (44), $\mathrm{NO}(30)$ and $\mathrm{N}_{2}$ (28). Similarly, $\mathrm{CO}$ interferes with $\mathrm{N}_{2}$ as it has the same $\mathrm{m} / \mathrm{z}(28){ }^{\mathrm{j}}$ The MS measured the sample concentration approximately every 6-7 seconds.

The FTIR measured $\mathrm{CO}, \mathrm{CO}_{2}, \mathrm{H}_{2} \mathrm{O}, \mathrm{N}_{2} \mathrm{O}, \mathrm{NO}, \mathrm{NO}_{2}, \mathrm{SO}_{2}$, and various organic species. The only organic species detected was a small amount $(<16 \mathrm{ppm})$ of methane $\left(\mathrm{CH}_{4}\right)$. The FTIR measured the gas concentrations about every 3.5 seconds. The gas chromatograph was used to measure $\mathrm{H}_{2}, \mathrm{O}_{2}, \mathrm{~N}_{2}, \mathrm{CO}_{2}$, and $\mathrm{N}_{2} \mathrm{O}$. The sampling frequency of the $\mathrm{GC}$ was one sample every 4 minutes.

\footnotetext{
${ }^{\mathrm{h}}$ Due to a focusing issue, the SRNL camera was not utilized during testing.

${ }^{\mathrm{i}}$ Approximately $8 \mathrm{scfm}$ enters the camera for cooling and approximately $7 \mathrm{scfm}$ is vented; at normal conditions, only $1 \mathrm{scfm}$ enters the melter.

${ }^{j}$ The interference of $\mathrm{CO}$ on $\mathrm{N}_{2}$ is negligible. The interferences of $\mathrm{N}_{2} \mathrm{O}$ on $\mathrm{CO}_{2}, \mathrm{NO}$ and $\mathrm{N}_{2}$ can be approximately accounted for during post-run processing of the data. Post-run processing of Chemical Process Cell (CPC) data has shown these corrections to be very accurate.
} 


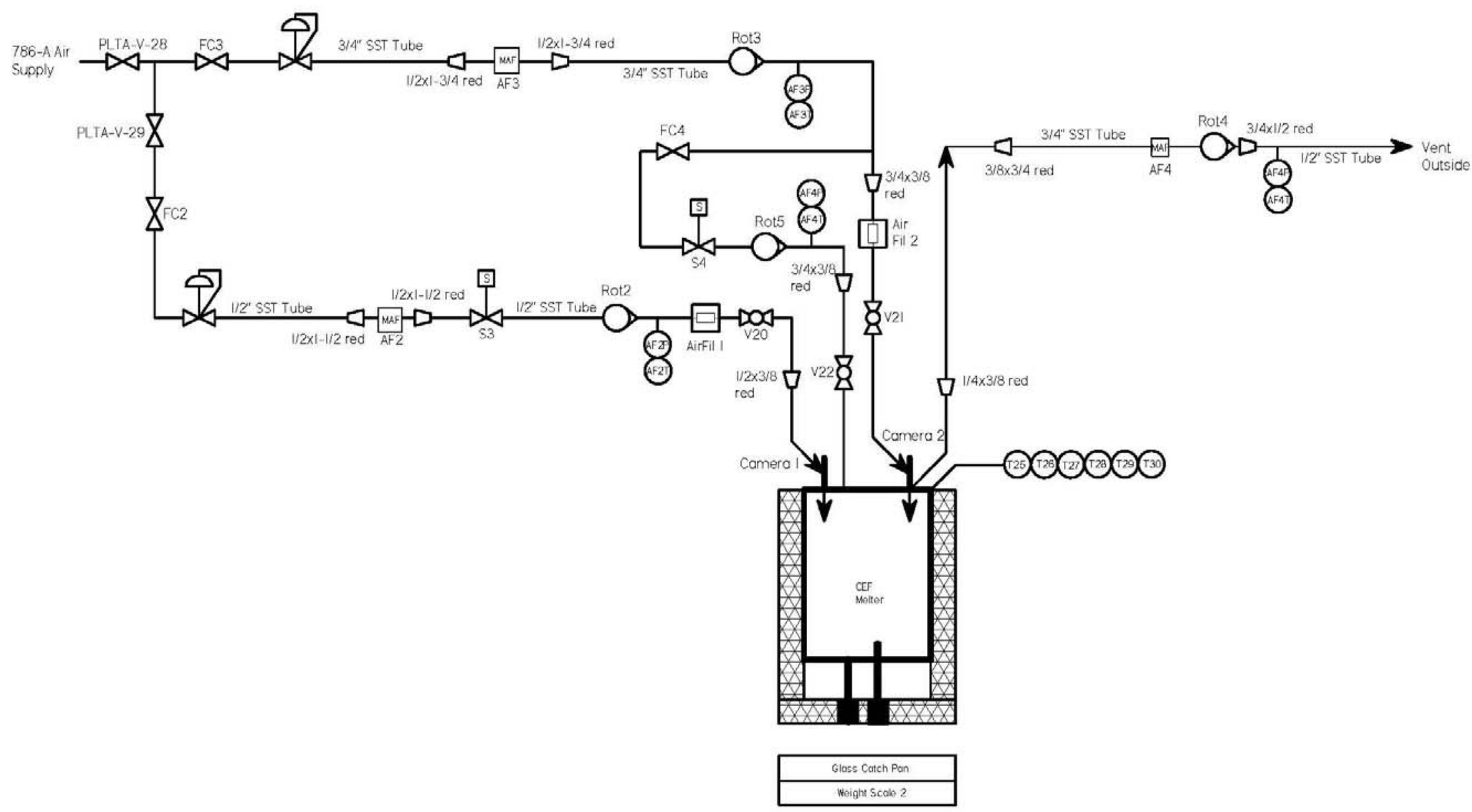

Figure 2-5. CEF camera system sketch. 


\subsection{Experimental Procedure}

\section{1 $\underline{\text { Melter Feed }}$}

The processing strategy for the Sludge Receipt and Adjustment Tank (SRAT) product run was developed by SRNL to prepare melter feed from SRAT product that meets the following guidelines. ${ }^{36}$

- Nitric/formic acid Flowsheet at $105 \%$ Koopman $^{37}$ acid stoichiometry

- Nitrate between 15,000 and $30,000 \mathrm{mg} / \mathrm{kg}$ slurry

- No noble metals or mercury ${ }^{38}$

- Total organic carbon (TOC) must meet current DWPF limits

- $\operatorname{REDOX}\left(\mathrm{Fe}^{2+} / \mathrm{Fe}\right.$ total) between 0.10 and 0.25 ; the higher end of this range is desired

- Yield stress $<25 \mathrm{~Pa}$

- Total solids after frit addition: 42 to $50 \mathrm{wt} \%$

- Antifoam added: 1000 to $2000 \mathrm{mg} / \mathrm{kg}$ on a carbon basis

- Abbreviated SRAT cycle (compared to typical DWPF processing), no Slurry Mix Evaporator (SME) cycle $^{36}$

- No Actinide Removal Process (ARP) or Modular Caustic Side Solvent Extraction Unit (MCU) material added (sludge only)

The SB6i simulant was produced by BlueGrass Chemical Specialties, LLC ${ }^{\mathrm{k}}$ and was processed into SRAT product by an abbreviated SRAT cycle at Harrell Industries, Inc. ${ }^{l}$ in March 2013. A sample was analyzed by SRNL for verification prior to shipment and a memo recommending acceptance of the SRAT batch was issued. ${ }^{39}$ The SRAT product was transferred into 30-gallon poly drums at Harrell Industries and shipped to SRNL in April 2013. Results of the analysis performed at SRNL as part of the SRAT product acceptance is summarized in Table 3-1 through Table 3-4.

The melter feed used for the CEF testing was produced by combining the Harrell Industries SB6i SRAT product with dry Frit 418 (no slurry) at a target waste loading of $36 \%$. Additional water was added to yield a total solids content of $42 \%$ in order to facilitate feeding.

Table 3-1. Physical Properties of the Harrell SB6i SRAT Product

\begin{tabular}{lll}
\hline Property & Meas ure d Value & Units \\
\hline Total Solids & 28.3 & weight $\%$ \\
\hline Insoluble Solids & 15.8 & weight $\%$ \\
\hline Soluble Solids & 12.5 & weight $\%$ \\
\hline Calcine Solids & 17.7 & weight $\%$ \\
\hline Slurry Density & 1.1494 & $\mathrm{~g} / \mathrm{mL}$ at $25^{\circ} \mathrm{C}$ \\
\hline Supernate Density & 1.0972 & $\mathrm{~g} / \mathrm{mL}$ at $25^{\circ} \mathrm{C}$ \\
\hline pH & 4.95 & \\
\hline Yield Stress & 4.0 & $\mathrm{~Pa}$ \\
\hline Consistency & 3.7 & $\mathrm{cP}$
\end{tabular}

\footnotetext{
${ }^{\mathrm{k}}$ The SB6i simulant was produced by BlueGrass Chemical Specialties, LLC of New Albany, IN.

${ }^{1}$ The SB6i SRAT product was produced by Harrell Industries, Inc. of Rock Hill, SC.
} 
Table 3-2. Harrell SB6i SRAT and BlueGrass Chemical SB6i Simulant Compositions

\begin{tabular}{ccc}
\hline Ele ment & $\begin{array}{c}\text { SRAT Product } \\
\text { wt\% calcine }\end{array}$ & $\begin{array}{c}\text { Simulant } \\
\text { solids }\end{array}$ \\
\hline $\mathrm{Al}$ & 13.9 & 14.3 \\
\hline $\mathrm{Ba}$ & 0.14 & 0.13 \\
\hline $\mathrm{Ca}$ & 1.2 & 1.2 \\
\hline $\mathrm{Cr}$ & 0.19 & 0.2 \\
\hline $\mathrm{Cu}$ & 0.12 & 0.1 \\
\hline $\mathrm{Fe}$ & 21.6 & 22.2 \\
\hline $\mathrm{K}$ & 0.26 & 0.25 \\
\hline $\mathrm{Mg}$ & 0.85 & 0.95 \\
\hline $\mathrm{Mn}$ & 6.72 & 7.1 \\
\hline $\mathrm{Na}$ & 13.2 & 13.1 \\
\hline $\mathrm{Ni}$ & 2.86 & 3.1 \\
\hline $\mathrm{P}$ & 0.1 & 0.1 \\
\hline $\mathrm{Pd}$ & $<0.010$ & $<0.010$ \\
\hline $\mathrm{S}$ & 0.31 & 0.3 \\
\hline $\mathrm{Si}$ & 1.49 & 1.3 \\
\hline $\mathrm{Sn}$ & 0.07 & not measured \\
\hline $\mathrm{Ti}$ & 0.05 & $<0.1$ \\
\hline $\mathrm{Zn}$ & 0.11 & 0.11 \\
\hline $\mathrm{Zr}$ & 0.19 & 0.26 \\
\hline & &
\end{tabular}

Table 3-3. Harrell SB6i SRAT Product Supernate Composition (mg/L)

\begin{tabular}{cc}
\hline Element & Supe rnate \\
\hline $\mathrm{Al}$ & 42.5 \\
\hline $\mathrm{Ba}$ & 0.45 \\
\hline $\mathrm{Ca}$ & 2730 \\
\hline $\mathrm{Cr}$ & 0.88 \\
\hline $\mathrm{Cu}$ & 58 \\
\hline $\mathrm{Fe}$ & 0.64 \\
\hline $\mathrm{K}$ & 1050 \\
\hline $\mathrm{Mg}$ & 1970 \\
\hline $\mathrm{Mn}$ & 9080 \\
\hline $\mathrm{Na}$ & 33,900 \\
\hline $\mathrm{Ni}$ & 1600 \\
\hline $\mathrm{P}$ & 0.64 \\
\hline $\mathrm{Pb}$ & 0.53 \\
\hline $\mathrm{S}$ & 624 \\
\hline $\mathrm{Si}$ & 260 \\
\hline $\mathrm{Sn}$ & 6.08 \\
\hline $\mathrm{Sr}$ & 4.90 \\
\hline $\mathrm{Ti}$ & $<0.100$ \\
\hline $\mathrm{Zn}$ & 23.2 \\
\hline $\mathrm{Zr}$ & $<0.100$ \\
\hline
\end{tabular}

Table 3-4. Harrell SB6i SRAT Product Anions and TOC (mg/kg)

\begin{tabular}{lc}
\hline Species & Meas ured Value \\
\hline $\mathrm{F}$ & $<500$ \\
\hline $\mathrm{Cl}$ & 450 \\
\hline $\mathrm{NO}_{2}$ & $<500$ \\
\hline $\mathrm{NO}_{3}$ & 24,300 \\
\hline $\mathrm{TOC}$ & 17,400 \\
\hline
\end{tabular}

\begin{tabular}{lc}
\hline Species & Me as ured Value \\
\hline $\mathrm{SO}_{4}$ & 1080 \\
\hline $\mathrm{C}_{2} \mathrm{O}_{4}$ & $<500$ \\
\hline $\mathrm{HCO}_{2}$ & 60,100 \\
\hline $\mathrm{PO}_{4}$ & $<500$ \\
\hline
\end{tabular}

\subsection{Startup Cullet}

The melter was loaded with $\sim 111 \mathrm{~kg}$ of SB6-Frit 418 startup cullet at 36\% waste loading from the 2010 campaign and its level in the vessel was approximately 17-19" from the site port seal surface. This glass was chosen since it was similar in composition to the material being fed to the CEF during Phase I testing, thus reducing the quantity of feed required for the test and the time involved to reach steady state conditions.

\subsection{Sample Analysis}

\subsubsection{Weight Percent Solids}

Total, dissolved and/or calcined solids were measured by the Process Science Analytical Laboratory 
(PSAL) for the melter feed, filter solids and condensate samples per procedure. ${ }^{40}$

\subsubsection{Composition Measurements}

Melter feed, off-gas system bag filter solids and glass samples were prepared by PSAL using the following fusions: sodium peroxide/sodium hydroxide ${ }^{41}$, lithium metaborate ${ }^{42}$ and lithium tetraborate/lithium nitrate ${ }^{43}$ for cations and potassium hydroxide ${ }^{44}$ and aqua regia ${ }^{45}$ for anions. Cations were measured with Inductively Coupled Plasma - Atomic Emission Spectroscopy (ICP-AES) and anions were measured with Ion Chromatography (IC). ${ }^{46,47}$ Total inorganic carbon (TIC) and TOC were measured by Analytical Development (AD) per procedure. ${ }^{48}$

\subsubsection{Glass Sample Reduction/Oxidation (REDOX) Measurements}

Glass samples were crushed, dissolved and analyzed by PSAL via Ultraviolet-visible (UV-Vis) spectroscopy according to procedure. ${ }^{49}$

\subsection{Results and Discussion}

A readiness assessment was conducted prior to testing and is summarized in SRNL-L3100-2013-00071. ${ }^{50}$ The objectives and general operating conditions for Phase I testing were detailed in SRNL-L3100-2013$00045 .^{51}$

Note that all data collected by the data acquisition system (DAS) every 30 seconds throughout testing is available in SRNL-L3100-2013-00189. ${ }^{52}$ Plots of data collected throughout testing are shown in Figure A-1 through Figure A-12 and include:

- Bottom thermocouple temperatures

- Side thermocouple temperatures

- Vapor space thermocouple temperatures

- Glass pool thermocouple temperatures

- Air flows

- Argon bubbler flows

- Vapor space and off-gas line pressures

- Heater outputs

- Feed rate

\subsection{Melter Heat-up}

The melter was energized on May $29^{\text {th }}, 2013$ at approximately 09:30 and ramped to operating temperature in approximately 14 hours. The vapor space heaters were ramped in manual mode to a target temperature in the range of $700-750^{\circ} \mathrm{C}$. The side and bottom heaters were operated in automatic ramp mode at $3^{\circ} \mathrm{C}$ per minute until the temperature approached the target temperature of $1125^{\circ} \mathrm{C}$, at which point manual mode was used. The pour heater and auxiliary pour tube rod heater were controlled in manual mode as needed to facilitate pouring of the cullet once melting had occurred. Standard air flows were used during this time. ${ }^{\mathrm{m}}$ After control thermocouples ${ }^{\mathrm{n}}$ reached the target temperature of $\sim 1125^{\circ} \mathrm{C}$, approximately 1 hour was required for the melt pool to reach a temperature in the range of $1000-1050^{\circ} \mathrm{C}$.

\subsection{Turnover}

The first feed addition occurred on May $30^{\text {th }}, 2013$ at approximately 01:15. Approximately 24 hours of feeding in the range of 189-357 $\mathrm{g} / \mathrm{min}$ under argon bubbling ( 0.1-0.5 scfm) were required to complete

\footnotetext{
${ }^{\mathrm{m}} 16.2 \mathrm{scfm}$ (AF1 - film cooler), $8.4 \mathrm{scfm}$ (AF2 - camera 1), $8.2 \mathrm{scfm}$ (AF3 - camera 2 inlet), $7.2 \mathrm{scfm}$ (AF4 - camera 2 outlet) and $0.7 \mathrm{scfm}$ (AF5 - melter stoke air).

${ }^{\mathrm{n}} \mathrm{T} 1$ - bottom, T3 through T10 - side (whichever thermocouple is reading the highest temperature) and T12 - vapor space.
} 
one turnover of the melter volume. Approximately $115 \mathrm{~kg}$ of glass were poured from the melter. ${ }^{0}$ This time was also used to monitor temperature and controller responses throughout the system. The average melt pool temperature during turnover was approximately $990^{\circ} \mathrm{C}$, while the vapor space was maintained at an average temperature of $714^{\circ} \mathrm{C}$. It should be noted that the relatively low average melt pool temperature can be attributed to the significant drops in temperature of thermocouple T13 throughout turnover. It is possible that the feed rate was far too high at times, which caused a buildup of cold cap or the thermocouple itself was faulty. The average melt pool temperature based off of T14 alone was $1012^{\circ} \mathrm{C}$. Melter turnover was completed on May 31, 2013 at approximately 00:15.

\subsection{Steady State Vapor Space Conditions}

Multiple vapor space temperatures (approximately $700^{\circ} \mathrm{C}, 600^{\circ} \mathrm{C}, 500^{\circ} \mathrm{C}, 400^{\circ} \mathrm{C}, 350^{\circ} \mathrm{C}$, and $300^{\circ} \mathrm{C}$ ) were evaluated during non-bubbled testing. ${ }^{\mathrm{p}}$ The goal was to maintain steady state conditions at reduced temperatures and monitor the off-gas composition. Steady state conditions were defined by three parameters, (i) vapor space temperature, (ii) feed rate and (iii) off-gas readings $\left(\mathrm{H}_{2}, \mathrm{CO}_{2}\right.$ and $\left.\mathrm{NO}_{\mathrm{x}}\right)$. The values should fluctuate less than $\pm 15 \%$ with no noticeable trend up or down. The vapor space temperature was incrementally lowered from the nominal $750^{\circ} \mathrm{C}$ in order to establish steady state feeding/pouring conditions at the target temperatures. The initial reductions in the vapor space temperature were achieved by lowering the set point on the vapor space heater control. The cold cap coverage was monitored and feed rate adjusted as necessary during the process. As lower temperatures were targeted $\left(\leq 500^{\circ} \mathrm{C}\right)$, it also became necessary to add purge air followed by small increases in cooling air to the J.M. Canty, Inc. camera. As the vapor space temperatures were lowered, the air to the film cooler could be reduced since the exiting off-gas was also at a lower temperature. It should be noted that a discussion of steady state and the flammability model assessment is provided in a separate report. ${ }^{9}$

\subsubsection{Vapor Space Test Conditions}

Changes to heater outputs and air flows were the primary tools used to vary the conditions. When necessary, feed rate was also adjusted to provide constant cold cap coverage for different conditions. It was desired to have approximately $90 \%$ cold cap coverage with some small vent holes in the cold cap rather than having 100\% cold cap coverage. The vent holes were monitored using the J.M. Canty, Inc. camera, which allowed viewing of the cold cap in an area above one of the bubblers.

A combination of heater output, air flow and feed rate adjustments were used to achieve the various vapor space temperatures. In some cases several hours were required to achieve steady state conditions. The average temperatures and vapor space heater outputs are shown in Table 4-1.

Table 4-1. Vapor Space Temperature Conditions

\begin{tabular}{ccccccc}
\hline $\begin{array}{c}\text { Target } \\
\text { Vapor } \\
\begin{array}{c}\text { Space } \\
\text { Temp }\left({ }^{\circ} \mathbf{C}\right)\end{array}\end{array}$ & $\begin{array}{c}\text { Average } \\
\text { Vapor } \\
\text { Space } \\
\text { Temp }\left({ }^{\circ} \mathbf{C}\right)\end{array}$ & $\begin{array}{c}\text { Average } \\
\text { Melter } \\
\text { Bottom } \\
\text { Temp }\left({ }^{\circ} \mathbf{C}\right)\end{array}$ & $\begin{array}{c}\text { Average } \\
\text { Glass } \\
\text { Pool } \\
\text { Temp }\left({ }^{\circ} \mathbf{C}\right)\end{array}$ & $\begin{array}{c}\text { Average } \\
\text { Vapor } \\
\text { Space } \\
\text { Volts }\end{array}$ & $\begin{array}{c}\text { Average } \\
\text { Feed Rate } \\
(\mathbf{g} / \mathbf{m i n})\end{array}$ & $\begin{array}{c}\text { Approximate } \\
\text { Test } \\
\text { Duration } \\
\text { (minutes) }\end{array}$ \\
\hline 700 & 693 & 1124 & 1072 & 115 & 87 & 92 \\
\hline 600 & 596 & 1118 & 1071 & 69 & 82 & 122 \\
\hline 500 & 507 & 1117 & 1061 & 58 & 80 & 150 \\
\hline 400 & 409 & 1123 & 1063 & 40 & 60 & 121 \\
\hline 350 & 346 & 1125 & 1071 & 29 & 58 & 123 \\
\hline 300 & 287 & 1120 & 1066 & 7 & 54 & 120 \\
\hline
\end{tabular}

${ }^{\circ}$ Prior to testing the melter was filled with approximately $111 \mathrm{~kg}$ of SB6-Frit 418 cullet.

${ }^{\mathrm{p}}$ During non-bubbled conditions, bubbling rate was maintained at $0.001-0.01 \mathrm{scfm}$ per bubbler in order to reduce the risk of plugging the bubbler ports. 
Maintaining consistent cold cap coverage was a primary goal for steady state conditions and ultimately the flammability model assessment. Images of the cold cap throughout vapor space testing are shown in Figure 4-1 and Figure 4-2. Feed rate adjustments were made to keep some small vent holes in the cold cap during most test conditions. The fact that vent holes occur randomly meant that no vents were available in the camera field of view for prolonged periods, especially during low temperature testing. Extended periods were required to verify overfeeding conditions rather than reduction in vent hole generation. Deviations in the melt pool thermocouple temperatures (T13 and T14) were an indicator of overfeeding; however, as previously mentioned, there was a substantial delay between overfeeding and the subsequent temperature deviation. As the vapor space temperature was reduced during the testing, feed rate reductions were required to prevent overfeeding of the melter. The average feed rates calculated during each of the test periods are shown in Table 4-1.

\subsubsection{Melter Inleakage}

The estimated air inleakage at the different vapor space test conditions is shown in Table 4-2. During Phase I runs at vapor space temperatures of $300-400^{\circ} \mathrm{C}$, it became apparent that the melter pressure could not be maintained at the target value of -5 inwc under high purge air flow conditions. These additional air flows required testing at melter pressures approaching atmosphere when the vapor space temperature approached $300^{\circ} \mathrm{C}$. Table 4-3 shows the major sources of melter air and the corresponding melter pressure at each target vapor space temperature condition. The * on the final purge air value indicates a flow above the DAS programmed display range of the transmitter. The value observed on the transmitter was approximately $28 \mathrm{scfm}$.

Table 4-2. Estimated Melter Air Inleakage

\begin{tabular}{ccccccc}
\hline $\begin{array}{c}\text { Average Vapor Space } \\
\left.\text { Temperature } \mathbf{(}^{\mathbf{0}} \mathbf{C}\right)\end{array}$ & 693 & 596 & 507 & 409 & 346 & 287 \\
\hline $\begin{array}{c}\text { Calculated Air } \\
\text { Inleakage (scfm) }\end{array}$ & 8 & 8 & 9 & 11 & 10 & 8 \\
\hline
\end{tabular}

Table 4-3. Melter Air Flows

\begin{tabular}{ccccc}
\hline $\begin{array}{c}\text { Average Vapor } \\
\text { Space Temp } \\
\left({ }^{\circ} \mathbf{C}\right)\end{array}$ & $\begin{array}{c}\text { Film Cooler } \\
\text { Air Flow } \\
(\mathbf{s c f m})\end{array}$ & $\begin{array}{c}\text { Melter Purge } \\
\text { Air Flow } \\
(\mathbf{s c f m})\end{array}$ & $\begin{array}{c}\text { Canty Camera } \\
\text { Air Flow } \\
(\mathbf{s c f m})\end{array}$ & $\begin{array}{c}\text { Melter } \\
\text { Pressure } \\
(\text { inwc) }\end{array}$ \\
\hline 693 & 15 & 0.6 & 8 & -5.0 \\
\hline 596 & 15 & 0.6 & 8 & -5.2 \\
\hline 507 & 15 & 8 & 8 & -4.7 \\
\hline 409 & 8 & 19 & 8 & -3.5 \\
\hline 346 & 6 & 22 & 9 & -3.1 \\
\hline 287 & 6 & $24^{*}$ & 13 & -0.5 \\
\hline
\end{tabular}

\subsection{Bubbled Testing}

After completing the low vapor space steady state testing at approximately $300^{\circ} \mathrm{C}$, the vapor space temperature was raised back up to the nominal operating average temperature of $725^{\circ} \mathrm{C}$. Both bubblers were increased to approximately $0.5 \mathrm{scfm}($ total $\sim 1 \mathrm{scfm})$. The system was operated with these conditions until feeding was stopped on June 3, 2013 at 12:03. During this time, the feed rate was in the range of $149-249 \mathrm{~g} / \mathrm{min}$, with an average value of $213 \mathrm{~g} / \mathrm{min}$. Significant drops of the T13 melt pool temperature were also observed; however, the exact cause is unknown. It is possible that the feed rate was far too high at times, which caused a buildup of cold cap or the thermocouple itself was faulty. 


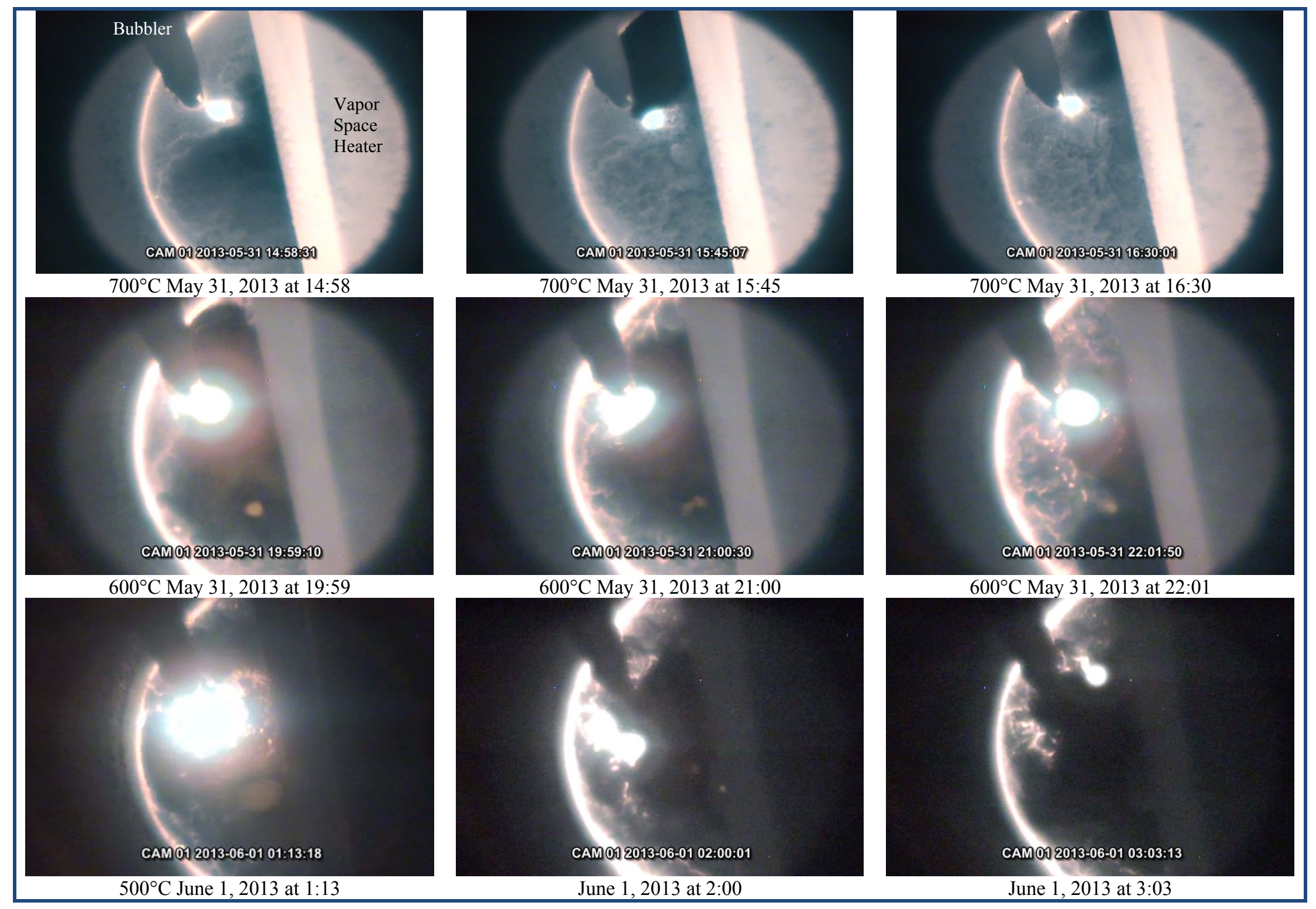

Figure 4-1. Images of CEF cold cap (vapor space target temperatures of 500-700 ${ }^{\circ} \mathrm{C}$ ). 


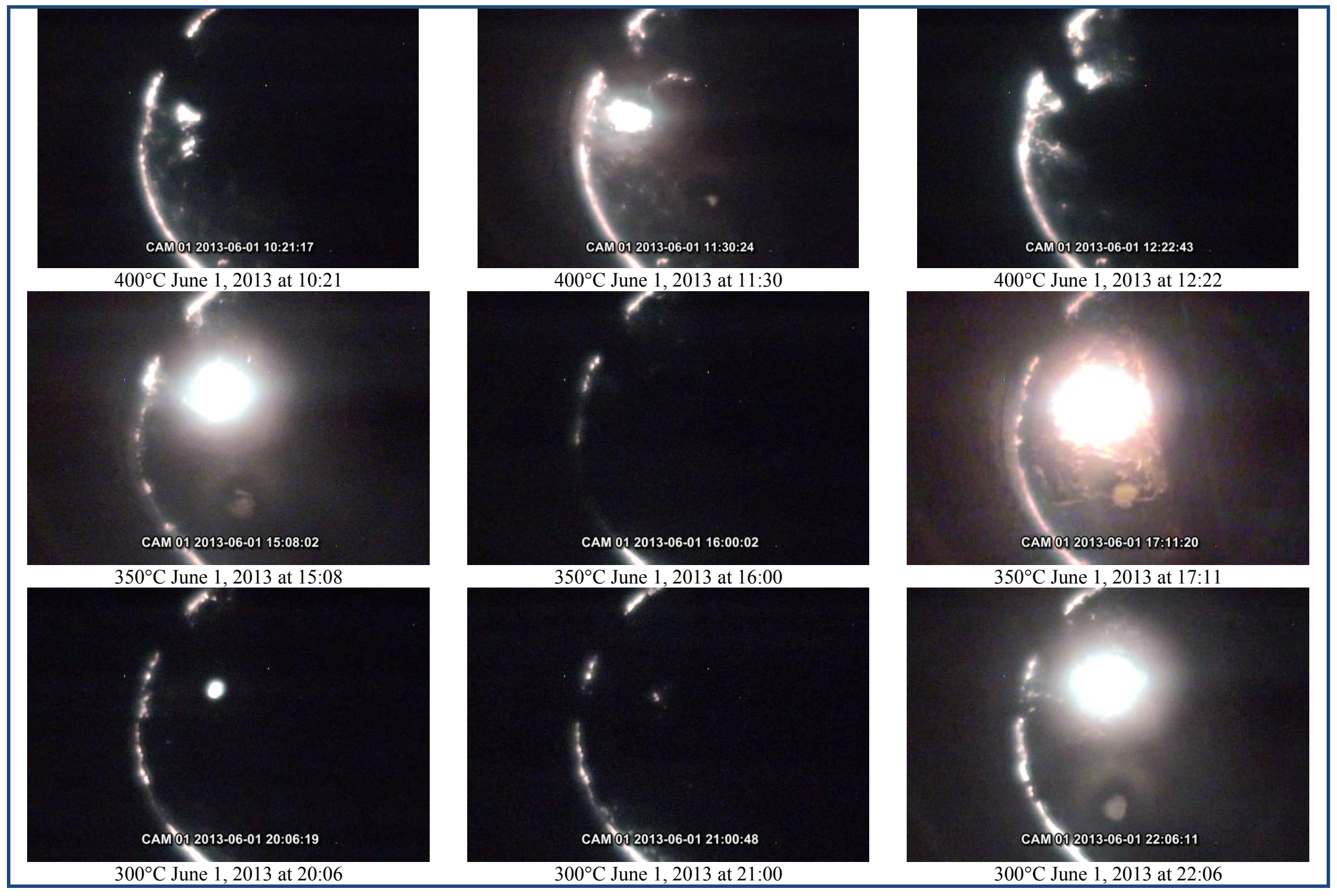

Figure 4-2. Images of CEF cold cap (vapor space target temperatures of $300-400^{\circ} \mathrm{C}$ ). 


\subsection{T13 Thermocouple Failure}

Within the first few hours after startup on May 29, 2013, it was noticed that thermocouple T13 was not showing any signs of heating compared to thermocouple T14 as shown in Figure 4-3. At approximately 11:17, T13 was tested and the circuit appeared to work properly.

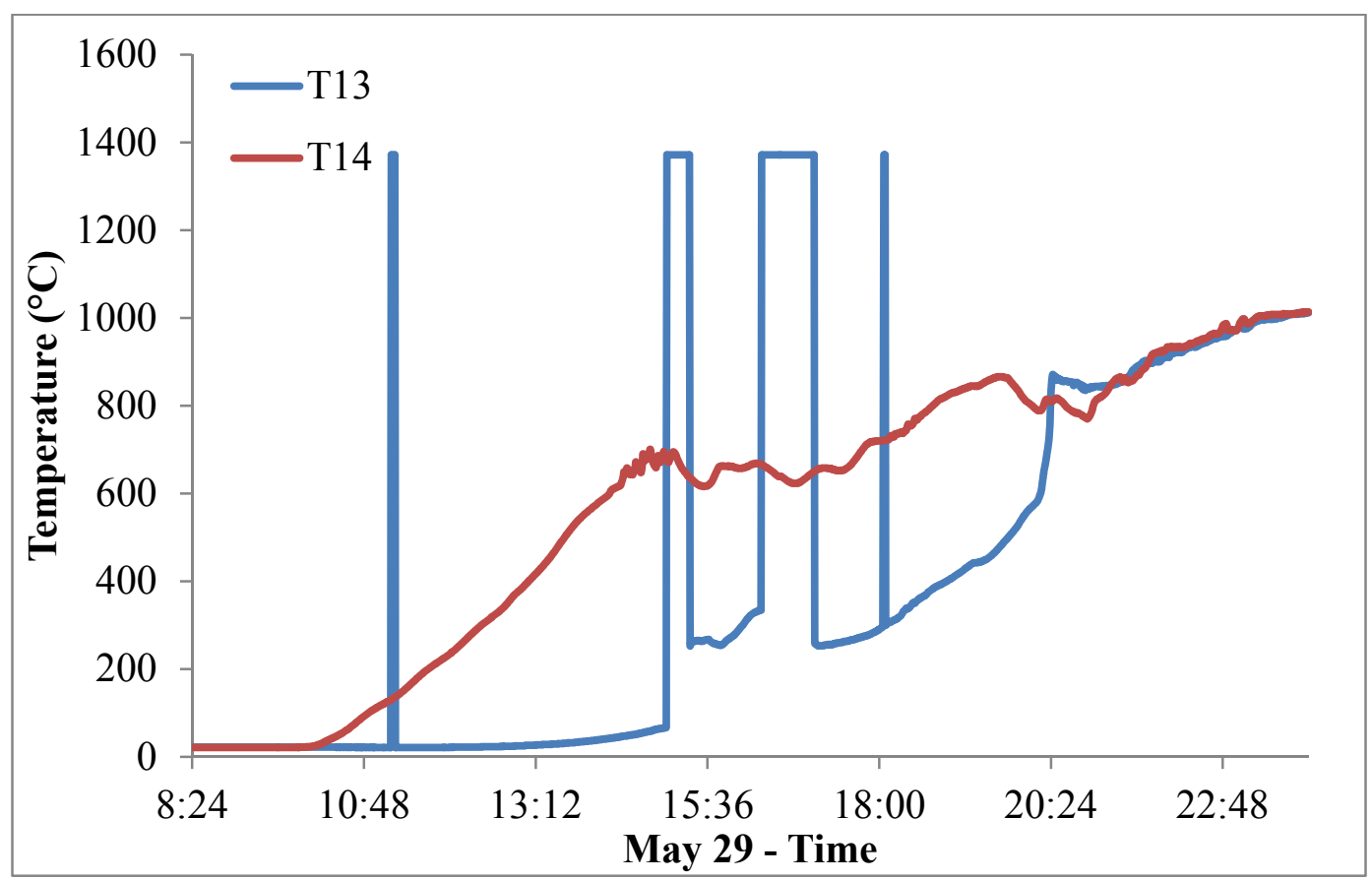

Figure 4-3. T13 thermocouple temperature as a function of time on May 29, 2013.

Based on the large temperature deviation observed between T13 and T14, it was decided to replace T13 $(\sim 15: 00)$. At 16:31 T13 was completely removed from the melter and a replacement was lowered into the glass pool at 17:10 and verified at 18:04. Within a few hours, comparable temperature readings were observed between T13 and T14. An immediate cause for the failure could not be determined. It was later determined that the connection was loose, which caused contact between the two thermocouple wires. Thus, the recorded temperatures were actually of the ambient conditions outside of the melter.

\subsection{Pour Tube Cartridge Heater Failure}

The auxiliary heater contains a thermocouple that provides information about the glass temperature inside of the chimney surrounding the upper portion of the pour tube. This thermocouple can be used as input for control of the heater.

The output on the new auxiliary pour heater was gradually increased along with the other heater systems during startup. At an output of $\sim 87 \%$ ( $~ 560$ watts), the heater failed on May 29, 2013 at approximately 23:49. Figure 4-4 shows the heater temperature and output as a function of time leading up to the failure. ${ }^{q}$ The failed heater was removed from the melt pool and replaced. It appears that the original heater failed near the start of the heated portion, which is slightly below the glass interface.

A wattage limit ( $\sim 175$ watts) was established for the new heater and it performed well throughout the remainder of the testing. The additional heater significantly improved the ability to maintain glass pool

\footnotetext{
${ }^{\mathrm{q}}$ Note that the momentary drop in heater output at 15:04 was accidental.
} 
temperature and pouring behavior, especially at the lower vapor space temperatures.

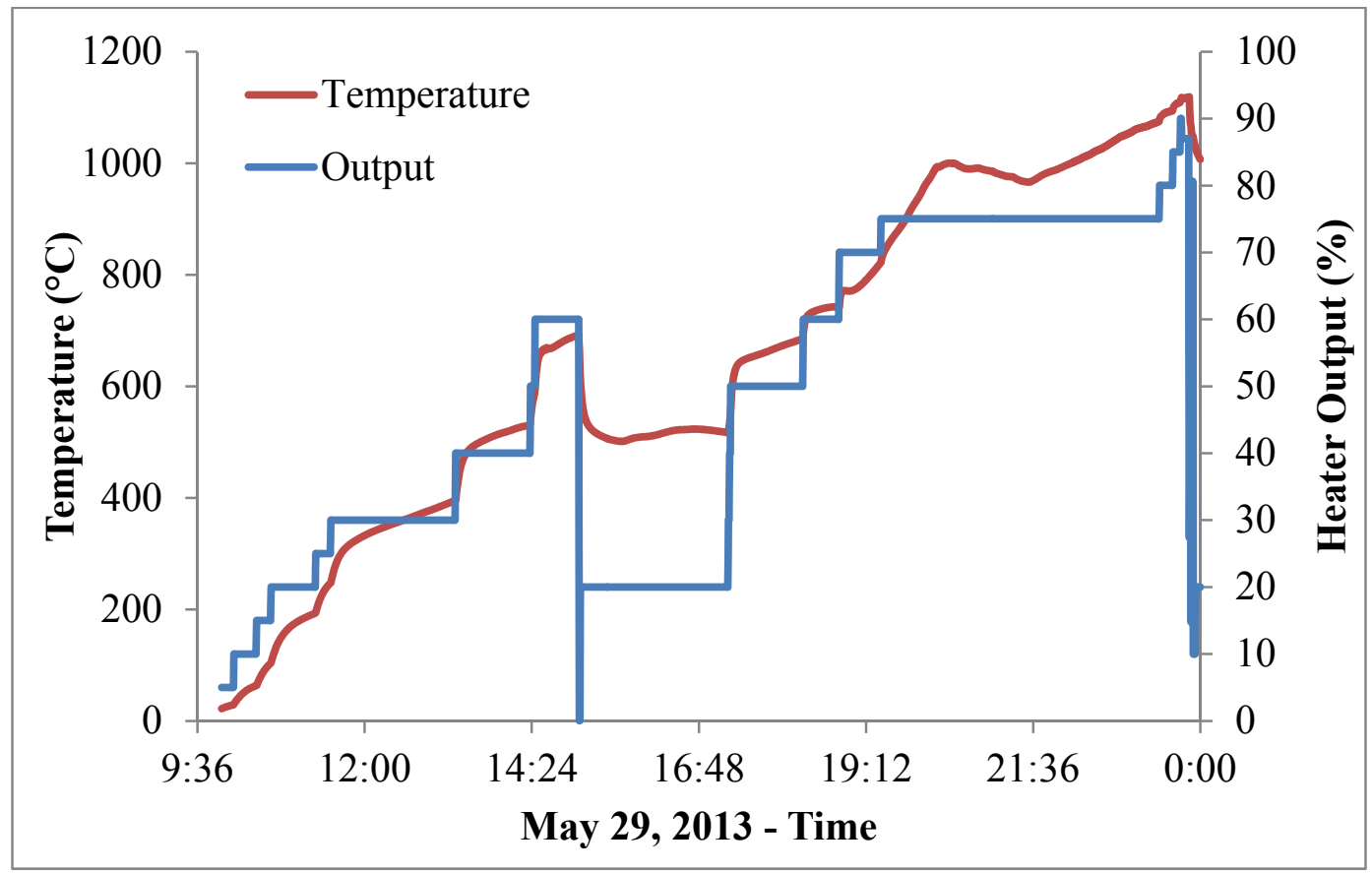

Figure 4-4. Pour tube heater output and temperature as a function of time prior to failure.

\subsection{Vessel Dimensional Documentation}

In support of future melter life assessments (see Section 2.1), the thermocouples that were welded to five of the six support blocks were monitored and recorded. Some support blocks were surrounded with reduced loose fill insulation in order to evaluate the possibility of additional cooling for creep reduction, if elevated temperatures were encountered. The remainder of the support blocks was surrounded by the normal method, which involves covering all exposed metal surfaces.

The average temperature for the different test conditions is shown in Table 4-4 and the recorded temperatures are shown in Figure 4-5. In general, support block temperature is approximately 50 degrees below the vapor space temperature during normal operating conditions. As the vapor space temperature decreases, the support temperatures also decrease and approach the actual temperature of the vapor space. It is important to note that all of the measured temperatures were well below the $1093^{\circ} \mathrm{C}$ value used to estimate the melter life based on creep concerns.

Table 4-4. Average Support Block Temperatures

\begin{tabular}{cc}
\hline $\begin{array}{c}\text { Average Vapor } \\
\text { Space Temperature }\left({ }^{\circ} \mathrm{C}\right)\end{array}$ & $\begin{array}{c}\text { Average Support } \\
\text { Block Temperature }\left({ }^{\circ} \mathrm{C}\right)\end{array}$ \\
\hline 693 & 657 \\
\hline 596 & 546 \\
\hline 507 & 466 \\
\hline 409 & 378 \\
\hline 346 & 334 \\
\hline 287 & 292 \\
\hline
\end{tabular}




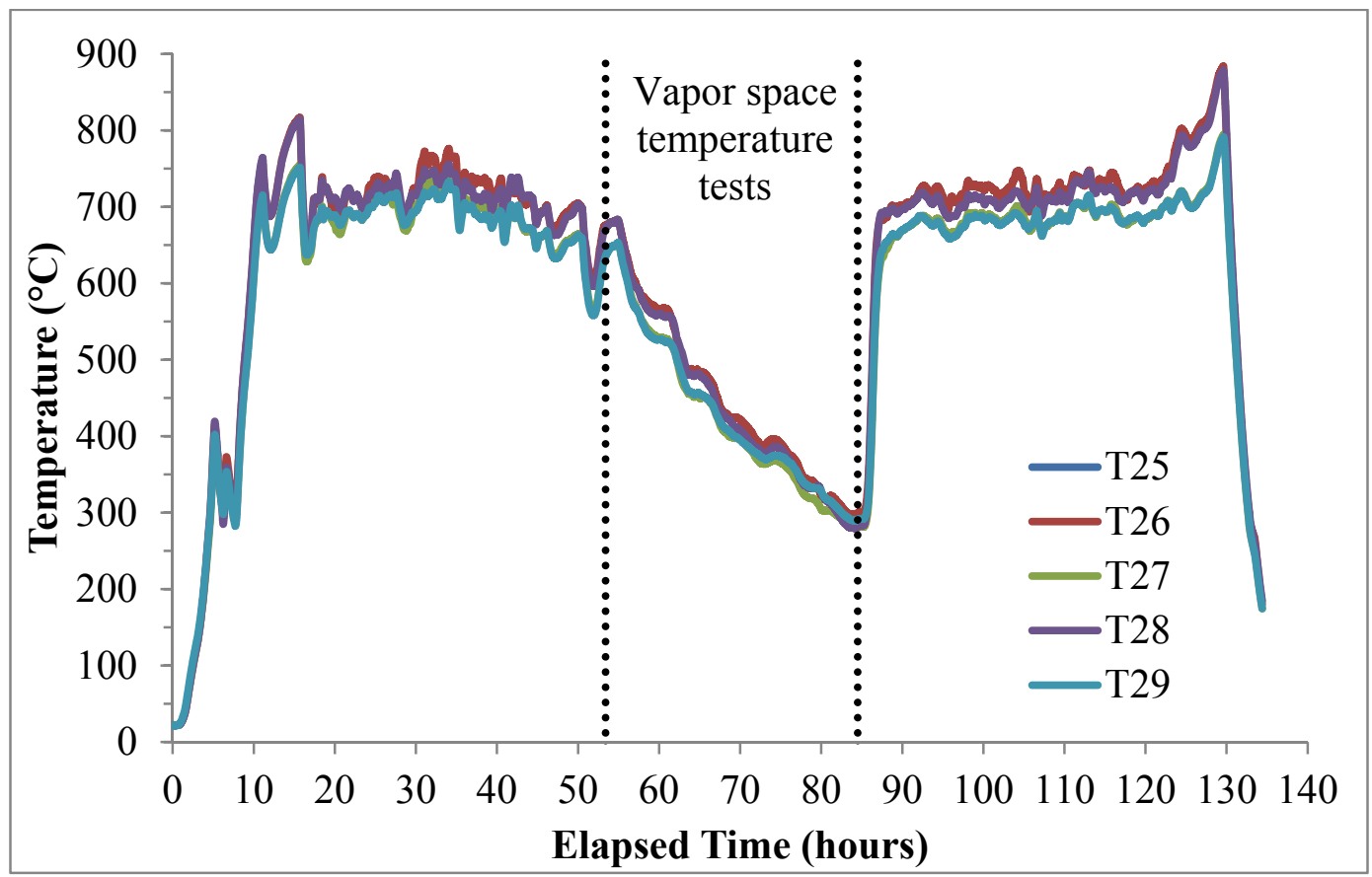

Figure 4-5. Support block temperatures throughout testing.

Prior to the start of Phase I testing, the melter vessel had been operated for approximately 250 hours during 2010 testing. Phase I testing resulted in an additional 135 hours, so the current total operational hours on the melter vessel is approximately 385 hours. Future Phase II testing will add 432 hours assuming a test duration of 18 days; however, the total operational hours will still be well below the recommended service life of 1250 hours (see Section 2.1 for more information).

\section{8 $\underline{\text { Sampling }}$}

Samples were taken on a regular basis throughout the entire campaign. Feed samples were collected each time a new 55 gallon drum of melter feed was prepared. Glass samples were pulled from the pour stream at $\sim 25 \mathrm{~kg}$ (glass poured) intervals. Condensate samples were taken from the overflow tank in the OGCT recirculation line hourly. The $25 \mu \mathrm{m}$ bag filters ${ }^{\mathrm{r}}$ were removed from service when the discharge pressure dropped by $\sim 3$ psi. The bags were dried at $50^{\circ} \mathrm{C}$ and the solids were collected for analysis. The complete sets of sample results are shown in Appendix A Table A-1 through Table A-14. Dates and approximate times for the vapor space temperature tests are provided for reference in Table 4-5.

\subsubsection{Feed Analysis}

The measured compositions of all seven batches of melter feed are shown in Table 6-1 and Table 6-2. ${ }^{\mathrm{s}}$ Some of the analytes were below the detection limit of the instrument and are noted by a result preceded by a " $<$." The relative standard deviation (\%RSD) values for a majority of the feed constituents are less than $5 \%$, which confirms that the melter feed was batched consistently. The measured TOC content of the melter feed was in the range of $14,400-16,900 \mu \mathrm{g} / \mathrm{mL}$.

\footnotetext{
${ }^{\mathrm{r}}$ The filters are located after the recirculation pump, but before the booster pump on the condensate system, which protects the multistage pump used to supply water to the quencher.

${ }^{\mathrm{s}}$ Note that the increase in $\mathrm{SO}_{4}$ concentration amongst the feed batches and \%RSD of $\sim 17 \%$ can most likely be attributed to the analysis rather than the samples themselves since the concentrations of the other detectable anions $\left(\mathrm{Cl}_{1} \mathrm{NO}_{3}\right.$ and $\left.\mathrm{HCO}_{2}\right)$ are consistent with $\%$ RSD values less than $2 \%$.
} 
SRNL-STI-2014-00005

Revision 0

Table 4-5. Vapor Space Temperature Test Dates and Approximate Times

\begin{tabular}{cccc}
\hline Vapor Space Te mpe rature & Date & Start & End \\
\hline $700^{\circ} \mathrm{C}$ & $5 / 31 / 2013$ & $14: 57$ & $16: 29$ \\
\hline $600^{\circ} \mathrm{C}$ & $5 / 31 / 2013$ & $19: 58$ & $22: 00$ \\
\hline $500^{\circ} \mathrm{C}$ & $6 / 1 / 2013$ & $01: 12$ & $03: 02$ \\
\hline $400^{\circ} \mathrm{C}$ & $6 / 1 / 2013$ & $10: 20$ & $12: 21$ \\
\hline $350^{\circ} \mathrm{C}$ & $6 / 1 / 2013$ & $15: 07$ & $17: 10$ \\
\hline $300^{\circ} \mathrm{C}$ & $6 / 1 / 2013$ & $20: 05$ & $22: 05$ \\
\hline
\end{tabular}

\subsubsection{Condensate Analysis}

The $\mathrm{pH}$ values of all collected samples were in the range of $7.74-7.95$ and densities were in the range of $0.9982-0.9985 \mathrm{~g} / \mathrm{cm}^{3}$. Solids were below the detection limit of $0.1 \%$. The measured compositions of select condensate samples are shown in Table 6-3 and Table 6-4. A majority of these samples were collected during the vapor space tests (see Table 4-5). Note that $\mathrm{F}, \mathrm{NO}_{3}, \mathrm{SO}_{4}, \mathrm{PO}_{4}, \mathrm{HCO}_{2}$ and $\mathrm{C}_{2} \mathrm{O}_{4}$ were below the detection limits for all measured samples and $\mathrm{Cl}$ and $\mathrm{NO}_{2}$ were below the detection limits except for those samples shown in Table 6-4. In general, the concentration of components in the condensate increased with time, which is to be expected since the condensate system was closed and recirculated throughout the duration of the six-day test. Previous testing has shown that in condensate liquids with a $\mathrm{pH}$ greater than 7 , the equilibria chemistry is shifted and nitrite concentration increases at the expense of nitrate concentration, which would account for the nitrite presence in the CEF condensate liquid. ${ }^{53}$ The measured total carbon was in the range of $61.8-76.1 \mu \mathrm{g} / \mathrm{mL}$ (more details are provided in Appendix A Table A-9). TOC was in the range of $21.3-25.9 \mu \mathrm{g} / \mathrm{mL}$ and TIC was in the range of $40-$ $51.1 \mu \mathrm{g} / \mathrm{mL}$. The presence of TIC can be attributed to the atmospheric adsorption of $\mathrm{CO}_{2}$ at $\mathrm{pH}$ greater than 7.

\subsubsection{Off-gas Filter Solids Analysis}

The measured compositions of each of the bag filters used during testing are shown in Table 6-5 and Table 6-6. Total solids content was in the range of $96-97.2 \%$.

\subsubsection{Glass Analysis}

The measured glass compositions of select samples are shown in Table 6-7. Some of the analytes were below the detection limit of the instrument and are noted by a result preceded by a " $<$." \%RSD values for the major glass components $(>0.5 \mathrm{wt} \%)$ are less than $10 \%$, which confirms a consistent melter feed batching. A comparison of the expected glass composition, melter feed composition and measured glass composition is shown in Table 6-8. The calculated glass composition was determined by combining the measured SB6i SRAT product ${ }^{39}$ received from Harrell Industries, Inc. with the target Frit 418 composition at a waste loading of $36 \%$. No significant deviations are present between the calculated glass composition and the measured feed and glass compositions, which indicates that the melter feed was batched correctly. The $\mathrm{Fe}^{2+} / \Sigma \mathrm{Fe}$ ratios for all glass samples are in the range of $0.08-0.20$ and are shown in Table 6-9. Compared to the REDOX crucible tests performed with the Harrell SB6i SRAT product prior to testing, these values are somewhat lower (more oxidized) than the measured $\mathrm{Fe}^{2+} / \Sigma \mathrm{Fe}$ crucible value of 0.26 . A cause for the deviation is unknown at this time; however, it maybe be related to sources of air in the melter as opposed to a closed crucible system. 


\subsection{Off-gas Analysis}

Continuous monitoring of the off-gas stream was conducted using the mass spectrometer, gas chromatograph and FTIR. The primary components of interest were $\mathrm{CO}, \mathrm{CO}_{2}, \mathrm{H}_{2}$, and to a lesser extent $\mathrm{NO}$ and $\mathrm{NO}_{2}$. Only an overview of the off-gas analysis is presented in this report. A discussion of the off-gas analysis and relationship of this data to the flammability model assessment is provided in a separate report. ${ }^{9}$ Hydrogen generation during bubbled and non-bubbled conditions was an area of particular interest. A plot of the $\mathrm{H}_{2}$ generation during both conditions is shown in Figure 6-1. Data for $\mathrm{CO}_{2}, \mathrm{CO}$, and $\mathrm{NO}_{\mathrm{x}}$ are shown in Figure 6-2 through Figure 6-4. The decrease in gas concentrations between 35 hours and 70 hours is due to the increased air purges used during steady state vapor space temperature testing, which resulted in more air dilution.

\subsection{Conclusions}

Prior to startup, a number of improvements and modifications were made to the CEF, including addition of cameras, vessel support temperature measurement, and a heating element near the pour tube. After charging the CEF with cullet from a previous Sludge Batch 6 (SB6) run, the melter was slurry-fed with SB6-Frit 418 melter feed at 36\% waste loading and was operated continuously for 6 days. Process data was collected throughout testing and included melter operation variables and off-gas chemistry. In order to satisfy the objective of Phase I testing, vapor space steady testing in the range of $\sim 300^{\circ} \mathrm{C}-700^{\circ} \mathrm{C}$ was conducted without argon bubbling to baseline the melter data to the existing DWPF melter flammability model. Adjustments to heater outputs, air flows and feed rate were necessary in order to achieve the vapor space temperatures in this range.

The results of the Phase I testing demonstrated that the CEF is capable of operating under the low vapor space temperatures. A melter pressure of -5 inches of water was not sustained throughout the run, but the melter did remain slightly negative even with the maximum air flows required for the lowest temperature conditions were used. The auxiliary pour tube heater improved the pouring behavior at all test conditions, including reduced feed rates required for the low vapor space testing. Argon bubbling can be used to promote mixing and increase feed rate at multiple conditions. Improvements due to bubbling have been determined previously; however, the addition of the cameras to the CEF allows for visual observation during a range of bubbling configurations. The off-gas analysis system proved to be robust and capable of operating for long durations.

The total operational hours on the melter vessel are approximately 385 hours. After Phase II testing, the anticipated total is expected to be approximately 820 hours, which is still well below the recommended service life of 1250 hours. Dimensional measurements taken prior to Phase I testing and support block temperatures recorded during Phase I testing are available if an extension of service life beyond 1250 hours is desired in the future.

\subsection{Recommendations}

The additional cooling/purge air required during testing pushed the limits of both the off-gas system and the existing flow meters. Either expanding the calibration range of the air flow meters or replacement where necessary would enhance the run data. A larger blower could increase vacuum capabilities on both the OGCT and melter. Installation of the repaired SRNL camera should give an additional view of the cold cap, which will improve feeding control. 
Table 6-1. Measured Melter Feed Composition (wt\% calcined at $\left.1100^{\circ} \mathrm{C}\right)$

\begin{tabular}{|c|c|c|c|c|c|c|c|c|c|}
\hline Sample ID & CEF1-F-059 & CEF1-F-060 & CEF1-F-061 & CEF1-F-062 & CEF1-F-063 & CEF1-F-064 & CEF1-F-065 & Average & $\%$ RSD \\
\hline Date & $5 / 30 / 2013$ & $5 / 30 / 2013$ & $5 / 30 / 2013$ & $5 / 31 / 2013$ & $6 / 2 / 2013$ & $6 / 2 / 2013$ & $6 / 3 / 2013$ & --- & --- \\
\hline Time & $1: 10$ & 8:00 & $16: 10$ & $4: 55$ & $1: 55$ & $14: 45$ & $6: 15$ & --- & --- \\
\hline $\mathrm{Al}_{2} \mathrm{O}_{3}$ & 9.58 & 10.16 & 9.70 & 9.46 & 9.89 & 9.65 & 9.91 & 9.77 & 2.3 \\
\hline $\mathrm{B}_{2} \mathrm{O}_{3}$ & 5.28 & 5.01 & 4.98 & 5.00 & 4.75 & 4.95 & 5.00 & 5.00 & 3.0 \\
\hline $\mathrm{BaO}$ & 0.05 & 0.05 & 0.05 & 0.05 & 0.05 & 0.05 & 0.05 & 0.05 & 2.4 \\
\hline $\mathrm{CaO}$ & 0.51 & 0.53 & 0.53 & 0.51 & 0.54 & 0.52 & 0.51 & 0.52 & 2.7 \\
\hline $\mathrm{Ce}_{2} \mathrm{O}_{3}$ & 0.07 & 0.08 & 0.08 & 0.07 & 0.08 & 0.07 & 0.07 & 0.07 & 4.8 \\
\hline $\mathrm{Cr}_{2} \mathrm{O}_{3}$ & 0.09 & 0.10 & 0.10 & 0.09 & 0.09 & 0.09 & 0.10 & 0.10 & 2.6 \\
\hline $\mathrm{Cu}_{2} \mathrm{O}$ & 0.09 & 0.11 & 0.09 & 0.07 & 0.06 & 0.07 & 0.08 & 0.08 & 22.4 \\
\hline $\mathrm{Fe}_{2} \mathrm{O}_{3}$ & 11.08 & 11.54 & 11.05 & 10.75 & 10.99 & 10.95 & 11.19 & 11.08 & 2.3 \\
\hline $\mathrm{K}_{2} \mathrm{O}$ & 0.15 & 0.16 & 0.15 & 0.15 & 0.16 & 0.15 & 0.16 & 0.16 & 2.1 \\
\hline $\mathrm{Li}_{2} \mathrm{O}$ & 4.92 & 4.75 & 4.83 & 4.93 & 4.93 & 4.97 & 4.95 & 4.90 & 1.6 \\
\hline $\mathrm{MgO}$ & 0.50 & 0.52 & 0.52 & 0.49 & 0.51 & 0.50 & 0.50 & 0.50 & 2.0 \\
\hline $\mathrm{Na}_{2} \mathrm{O}$ & 11.69 & 11.64 & 11.71 & 11.59 & 11.66 & 11.46 & 11.47 & 11.60 & 1.0 \\
\hline $\mathrm{NiO}$ & 1.27 & 1.33 & 1.28 & 1.22 & 1.23 & 1.23 & 1.25 & 1.26 & 3.1 \\
\hline $\mathrm{P}_{2} \mathrm{O}_{5}$ & $<0.23$ & $<0.23$ & $<0.23$ & $<0.23$ & $<0.23$ & $<0.23$ & $<0.23$ & $<0.23$ & --- \\
\hline $\mathrm{PbO}$ & $<0.11$ & $<0.11$ & $<0.11$ & $<0.11$ & $<0.11$ & $<0.11$ & $<0.11$ & $<0.11$ & --- \\
\hline $\mathrm{PdO}$ & $<0.12$ & $<0.12$ & $<0.12$ & $<0.12$ & $<0.12$ & $<0.12$ & $<0.12$ & $<0.12$ & --- \\
\hline $\mathrm{SO}_{4}$ & 0.29 & 0.27 & 0.29 & 0.28 & 0.29 & 0.30 & 0.30 & 0.29 & 3.9 \\
\hline $\mathrm{SnO}_{2}$ & 0.04 & 0.04 & 0.04 & 0.04 & 0.04 & 0.04 & 0.04 & 0.04 & 2.4 \\
\hline $\mathrm{SiO}_{2}$ & 49.94 & 48.61 & 49.11 & 49.75 & 48.41 & 48.94 & 50.31 & 49.30 & 1.7 \\
\hline $\mathrm{TiO}_{2}$ & 0.02 & 0.02 & 0.02 & 0.02 & 0.02 & 0.02 & 0.02 & 0.02 & 2.7 \\
\hline $\mathrm{ZnO}$ & 0.05 & 0.05 & 0.05 & 0.05 & 0.05 & 0.05 & 0.05 & 0.05 & 2.6 \\
\hline $\mathrm{ZrO}_{2}$ & 0.13 & 0.14 & 0.14 & 0.13 & 0.13 & 0.13 & 0.14 & 0.13 & 2.6 \\
\hline TOTAL & 99.39 & 98.86 & 98.42 & 98.18 & 97.51 & 97.65 & 99.66 & --- & --- \\
\hline
\end{tabular}


Table 6-2. Measured Melter Feed Anions (mg/kg)

\begin{tabular}{|c|c|c|c|c|c|c|c|c|c|}
\hline Sample ID & CEF1-F-059 & CEF1-F-060 & CEF1-F-061 & CEF1-F-062 & CEF1-F-063 & CEF1-F-064 & CEF1-F-065 & Average & $\%$ RSD \\
\hline Date & $5 / 30 / 2013$ & $5 / 30 / 2013$ & $5 / 30 / 2013$ & $5 / 31 / 2013$ & $6 / 2 / 2013$ & $6 / 2 / 2013$ & $6 / 3 / 2013$ & --- & --- \\
\hline Time & $1: 10$ & 8:00 & $16: 10$ & $4: 55$ & $1: 55$ & $14: 45$ & $6: 15$ & --- & --- \\
\hline $\mathrm{F}$ & $<500$ & $<500$ & $<500$ & $<500$ & $<500$ & $<500$ & $<500$ & $<500$ & --- \\
\hline $\mathrm{Cl}$ & 311 & 316 & 314 & 312 & 307.5 & 305 & 314.5 & 311 & 1.6 \\
\hline $\mathrm{NO}_{2}$ & $<500$ & $<500$ & $<500$ & $<500$ & $<500$ & $<500$ & $<500$ & $<500$ & --- \\
\hline $\mathrm{NO}_{3}$ & 17200 & 17700 & 17900 & 17700 & 17700 & 17650 & 17100 & 17564 & 1.8 \\
\hline $\mathrm{SO}_{4}$ & 445 & 568.5 & 633 & 701.5 & 701 & 736 & 750.5 & 648 & 16.6 \\
\hline $\mathrm{C}_{2} \mathrm{O}_{4}$ & $<500$ & $<500$ & $<500$ & $<500$ & $<500$ & $<500$ & $<500$ & $<500$ & --- \\
\hline $\mathrm{HCO}_{2}$ & 44600 & 46150 & 44950 & 45750 & 45750 & 45250 & 47200 & 45664 & 1.8 \\
\hline $\mathrm{PO}_{4}$ & $<500$ & $<500$ & $<500$ & $<500$ & $<500$ & $<500$ & $<500$ & $<500$ & --- \\
\hline
\end{tabular}


Table 6-3. Measured Condensate Cations (mg/L)

\begin{tabular}{|c|c|c|c|c|c|c|c|c|c|c|c|c|}
\hline Sample ID & Date & Time & Al & B & $\mathbf{C a}$ & $\mathrm{Cr}$ & Fe & $\mathbf{K}$ & $\mathbf{L i}$ & Mg & $\mathbf{N a}$ & Si \\
\hline CEF1-C-023 & $5 / 31 / 2013$ & $1: 15$ & 0.38 & 13.71 & 7.36 & 0.29 & 0.03 & 1.77 & 1.28 & 0.61 & 63.03 & 4.63 \\
\hline CEF1-C-036 & $5 / 31 / 2013$ & $14: 30$ & 0.43 & 17.81 & 7.71 & 0.32 & 0.03 & 1.94 & 1.65 & 0.68 & 75.89 & 4.85 \\
\hline CEF1-C-037 & $5 / 31 / 2013$ & $15: 30$ & 0.40 & 17.35 & 7.54 & 0.31 & 0.03 & 1.92 & 1.62 & 0.66 & 75.96 & 4.74 \\
\hline CEF1-C-038 & $5 / 31 / 2013$ & $16: 30$ & 0.36 & 17.38 & 7.63 & 0.32 & 0.03 & 1.95 & 1.65 & 0.68 & 79.18 & 4.92 \\
\hline CEF1-C-041 & $5 / 31 / 2013$ & $19: 30$ & 0.43 & 18.62 & 7.77 & 0.32 & 0.03 & 2.00 & 1.71 & 0.71 & 80.27 & 4.98 \\
\hline CEF1-C-042 & $5 / 31 / 2013$ & $20: 30$ & 0.51 & 18.50 & 7.72 & 0.32 & 0.03 & 2.01 & 1.70 & 0.70 & 79.17 & 5.02 \\
\hline CEF1-C-043 & $5 / 31 / 2013$ & $21: 30$ & 0.42 & 18.18 & 7.65 & 0.31 & 0.03 & 1.99 & 1.68 & 0.70 & 79.37 & 5.01 \\
\hline CEF1-C-044 & $5 / 31 / 2013$ & $22: 03$ & 0.49 & 18.88 & 7.71 & 0.32 & 0.03 & 2.06 & 1.70 & 0.71 & 82.04 & 5.15 \\
\hline CEF1-C-048 & $6 / 1 / 2013$ & $1: 30$ & 0.45 & 19.38 & 7.95 & 0.32 & 0.03 & 2.11 & 1.78 & 0.74 & 81.82 & 5.77 \\
\hline CEF1-C-049 & $6 / 1 / 2013$ & $2: 30$ & 0.42 & 19.21 & 7.81 & 0.32 & 0.03 & 2.09 & 1.76 & 0.74 & 84.11 & 5.96 \\
\hline CEF1-C-050 & $6 / 1 / 2013$ & $3: 06$ & 0.49 & 19.06 & 7.69 & 0.32 & 0.03 & 2.10 & 1.75 & 0.73 & 84.62 & 5.94 \\
\hline CEF1-C-058 & $6 / 1 / 2013$ & $10: 30$ & 0.49 & 19.25 & 7.81 & 0.32 & 0.03 & 2.14 & 1.80 & 0.76 & 84.74 & 6.51 \\
\hline CEF1-C-059 & $6 / 1 / 2013$ & $11: 30$ & 0.47 & 19.11 & 7.71 & 0.32 & 0.03 & 2.11 & 1.78 & 0.75 & 85.97 & 6.55 \\
\hline CEF1-C-060 & $6 / 1 / 2013$ & $12: 20$ & 0.53 & 18.69 & 7.52 & 0.31 & 0.03 & 2.06 & 1.74 & 0.73 & 84.95 & 6.31 \\
\hline CEF1-C-063 & $6 / 1 / 2013$ & $15: 30$ & 0.51 & 19.94 & 7.92 & 0.33 & 0.03 & 2.17 & 1.84 & 0.78 & 86.89 & 6.86 \\
\hline CEF1-C-064 & $6 / 1 / 2013$ & $16: 30$ & 0.53 & 19.14 & 7.66 & 0.31 & 0.03 & 2.19 & 1.78 & 0.75 & 87.05 & 6.64 \\
\hline CEF1-C-065 & $6 / 1 / 2013$ & $17: 25$ & 0.51 & 19.61 & 7.87 & 0.32 & 0.03 & 2.14 & 1.82 & 0.77 & 88.16 & 6.63 \\
\hline CEF1-C-068 & $6 / 1 / 2013$ & $20: 30$ & 0.54 & 18.98 & 7.57 & 0.31 & 0.03 & 2.08 & 1.77 & 0.74 & 86.75 & 6.29 \\
\hline CEF1-C-069 & $6 / 1 / 2013$ & $21: 30$ & 0.53 & 20.15 & 8.02 & 0.33 & 0.03 & 2.19 & 1.86 & 0.79 & 86.80 & 6.74 \\
\hline CEF1-C-070 & $6 / 1 / 2013$ & $22: 30$ & 0.55 & 19.75 & 7.82 & 0.32 & 0.03 & 2.14 & 1.82 & 0.76 & 87.76 & 6.53 \\
\hline CEF1-C-076 & $6 / 2 / 2013$ & $4: 30$ & 0.57 & 20.28 & 8.06 & 0.33 & 0.03 & 2.20 & 1.87 & 0.80 & 87.40 & 7.14 \\
\hline CEF1-C-082 & $6 / 2 / 2013$ & $10: 30$ & 0.61 & 18.87 & 7.60 & 0.31 & 0.03 & 2.08 & 1.77 & 0.75 & 87.24 & 6.61 \\
\hline CEF1-C-088 & $6 / 2 / 2013$ & $16: 00$ & 0.45 & 25.49 & 7.97 & 0.34 & 0.03 & 2.66 & 2.43 & 0.91 & 111.67 & 5.82 \\
\hline CEF1-C-094 & $6 / 2 / 2013$ & $22: 00$ & 0.48 & 27.62 & 7.79 & 0.34 & 0.03 & 2.73 & 2.53 & 0.90 & 115.59 & 5.97 \\
\hline CEF1-C-100 & $6 / 3 / 2013$ & $4: 00$ & 0.43 & 30.06 & 7.87 & 0.35 & 0.03 & 2.84 & 2.67 & 0.92 & 123.69 & 6.23 \\
\hline CEF1-C-108 & $6 / 3 / 2013$ & $12: 00$ & 0.43 & 34.19 & 8.24 & 0.37 & 0.03 & 3.15 & 2.98 & 0.98 & 129.10 & 6.52 \\
\hline
\end{tabular}


Table 6-4. Measured Condensate Anions (mg/L)

\begin{tabular}{ccccc}
\hline Sample ID & Date & Time & Cl & NO $_{2}$ \\
\hline CEF1-C-088 & $6 / 2 / 2013$ & $16: 00$ & 1.07 & 1.24 \\
\hline CEF1-C-094 & $6 / 2 / 2013$ & $22: 00$ & 1.11 & 1.315 \\
\hline CEF1-C-100 & $6 / 3 / 2013$ & $4: 00$ & 1.18 & 1.4 \\
\hline CEF1-C-108 & $6 / 3 / 2013$ & $12: 00$ & 1.27 & 1.5
\end{tabular}

Note that $\mathrm{F}, \mathrm{NO}_{3}, \mathrm{SO}_{4}, \mathrm{PO}_{4}, \mathrm{HCO}_{2}$ and $\mathrm{C}_{2} \mathrm{O}_{4}$ were below the detection limits for all measured samples.

Table 6-5. Measured Off-gas System Filter Solids Cations (wt \% elemental at $105^{\circ} \mathrm{C}$ )

\begin{tabular}{ccccc}
\hline Sample ID & CEF1-FL-A & CEF1-FL-M & CEF1-FL-Q & CEF1-FL-B \\
\hline Service Dates & $5 / 29-5 / 30 / 2013$ & $5 / 30-6 / 2 / 2013$ & $6 / 2-6 / 2 / 2013$ & $6 / 2-6 / 3 / 2013$ \\
\hline $\mathrm{Al}$ & 9.86 & 8.22 & 8.64 & 8.77 \\
\hline $\mathrm{B}$ & 0.75 & 0.85 & 0.57 & 0.71 \\
\hline $\mathrm{Ba}$ & 0.10 & 0.08 & 0.09 & 0.10 \\
\hline $\mathrm{Ca}$ & 0.62 & 0.54 & 0.75 & 0.65 \\
\hline $\mathrm{Ce}$ & 0.11 & 0.10 & 0.11 & 0.11 \\
\hline $\mathrm{Cr}$ & 0.14 & 0.17 & 0.17 & 1.27 \\
\hline $\mathrm{Cu}$ & 0.13 & 0.11 & 0.13 & 0.11 \\
\hline $\mathrm{Fe}$ & 19.81 & 16.84 & 20.00 & 19.24 \\
\hline $\mathrm{K}$ & 0.04 & 0.04 & 0.05 & 0.05 \\
\hline $\mathrm{Li}$ & 0.81 & 1.04 & 0.52 & 0.74 \\
\hline $\mathrm{Mg}$ & 0.66 & 0.58 & 0.72 & 0.65 \\
\hline $\mathrm{Mn}$ & 6.07 & 5.14 & 6.50 & 5.86 \\
\hline $\mathrm{Na}$ & 2.98 & 3.23 & 2.34 & 2.82 \\
\hline $\mathrm{Ni}$ & 2.56 & 2.20 & 2.66 & 2.56 \\
\hline $\mathrm{Pb}$ & $<0.1$ & $<0.1$ & $<0.1$ & $<0.1$ \\
\hline $\mathrm{Si}$ & 10.83 & 13.01 & 10.44 & 10.95 \\
\hline $\mathrm{Ti}$ & 0.04 & 0.05 & 0.05 & 0.06 \\
\hline $\mathrm{Zn}$ & 0.09 & 0.08 & 0.09 & 0.09 \\
\hline $\mathrm{Zr}$ & 0.11 & 0.11 & & \\
\hline
\end{tabular}


Table 6-6. Measured Off-gas System Filter Solids Anions (wt\%)

\begin{tabular}{ccccc}
\hline Sample ID & CEF1-FL-A & CEF1-FL-M & CEF1-FL-Q & CEF1-FL-B \\
\hline Service Dates & $5 / 29-5 / 30 / 2013$ & $5 / 30-6 / 2 / 2013$ & $6 / 2-6 / 2 / 2013$ & $6 / 2-6 / 3 / 2013$ \\
\hline $\mathrm{F}$ & $<0.05$ & $<0.05$ & $<0.05$ & $<0.05$ \\
\hline $\mathrm{Cl}$ & $<0.05$ & 0.24 & 0.21 & 0.07 \\
\hline $\mathrm{NO}_{2}$ & $<0.05$ & $<0.05$ & $<0.05$ & $<0.05$ \\
\hline $\mathrm{NO}_{3}$ & $<0.05$ & $<0.05$ & $<0.05$ & $<0.05$ \\
\hline $\mathrm{SO}_{4}$ & 0.15 & 0.12 & 0.17 & 0.21 \\
\hline $\mathrm{C}_{2} \mathrm{O}_{4}$ & 0.14 & 0.59 & 0.62 & 0.26 \\
\hline $\mathrm{HCO}_{2}$ & $<0.05$ & $<0.05$ & $<0.05$ & $<0.05$ \\
\hline $\mathrm{PO}_{4}$ & $<0.05$ & $<0.05$ & $<0.05$ & $<0.05$ \\
\hline
\end{tabular}


Table 6-7. Measured Glass Composition Data (wt\%)

\begin{tabular}{|c|c|c|c|c|c|c|c|c|}
\hline Sample ID & CEF1-GL-005 & CEF1-GL-007 & CEF1-GL-008 & CEF1-GL-009 & CEF1-GL-014 & CEF1-GL-016 & Average & $\%$ RSD \\
\hline Date & $5 / 30 / 2013$ & $5 / 31 / 2013$ & $5 / 31 / 2013$ & $6 / 1 / 2013$ & $6 / 2 / 2013$ & $6 / 3 / 2013$ & --- & --- \\
\hline Time & $21: 40$ & 11:17 & $22: 17$ & 11:11 & 22:08 & $9: 53$ & --- & --- \\
\hline $\mathrm{Al}_{2} \mathrm{O}_{3}$ & 10.17 & 9.97 & 9.89 & 9.68 & 9.69 & 9.60 & 9.83 & 2.2 \\
\hline $\mathrm{B}_{2} \mathrm{O}_{3}$ & 4.79 & 5.03 & 4.99 & 4.44 & 5.01 & 5.11 & 4.90 & 5.7 \\
\hline $\mathrm{BaO}$ & 0.04 & 0.04 & 0.05 & 0.05 & 0.05 & 0.06 & 0.05 & 13.0 \\
\hline $\mathrm{CaO}$ & 0.57 & 0.59 & 0.59 & 0.59 & 0.58 & 0.59 & 0.58 & 1.6 \\
\hline $\mathrm{Ce}_{2} \mathrm{O}_{3}$ & 0.05 & 0.06 & 0.06 & 0.06 & 0.07 & 0.07 & 0.06 & 13.8 \\
\hline $\mathrm{Cr}_{2} \mathrm{O}_{3}$ & 0.08 & 0.08 & 0.09 & 0.09 & 0.10 & 0.10 & 0.09 & 11.5 \\
\hline $\mathrm{CuO}$ & 0.07 & 0.07 & 0.06 & 0.06 & 0.06 & 0.06 & 0.06 & 7.2 \\
\hline $\mathrm{Fe}_{2} \mathrm{O}_{3}$ & 10.51 & 10.51 & 10.60 & 10.50 & 10.73 & 10.70 & 10.59 & 1.1 \\
\hline $\mathrm{K}_{2} \mathrm{O}$ & 0.10 & 0.12 & 0.12 & 0.12 & 0.13 & 0.13 & 0.12 & 7.9 \\
\hline $\mathrm{Li}_{2} \mathrm{O}$ & 4.73 & 4.88 & 4.86 & 4.61 & 4.84 & 4.87 & 4.80 & 2.5 \\
\hline $\mathrm{MgO}$ & 0.47 & 0.52 & 0.53 & 0.53 & 0.57 & 0.58 & 0.53 & 6.8 \\
\hline $\mathrm{MnO}_{2}$ & 3.79 & 3.83 & 3.84 & 3.78 & 3.87 & 3.86 & 3.83 & 1.0 \\
\hline $\mathrm{Na}_{2} \mathrm{O}$ & 12.26 & 12.05 & 11.99 & 11.79 & 11.72 & 11.77 & 11.93 & 1.7 \\
\hline $\mathrm{NiO}$ & 1.22 & 1.20 & 1.23 & 1.22 & 1.25 & 1.27 & 1.23 & 1.9 \\
\hline $\mathrm{PbO}$ & $<0.12$ & $<0.12$ & $<0.12$ & $<0.12$ & $<0.12$ & $<0.12$ & $<0.12$ & --- \\
\hline $\mathrm{SiO}_{2}$ & 49.82 & 50.84 & 50.47 & 48.80 & 50.83 & 50.33 & 50.18 & 1.8 \\
\hline $\mathrm{TiO}_{2}$ & 0.04 & 0.04 & 0.04 & 0.04 & 0.04 & 0.04 & 0.04 & 7.8 \\
\hline $\mathrm{ZnO}$ & 0.04 & 0.04 & 0.05 & 0.05 & 0.06 & 0.06 & 0.05 & 15.4 \\
\hline $\mathrm{ZrO}_{2}$ & 0.14 & 0.15 & 0.15 & 0.16 & 0.14 & 0.15 & 0.15 & 6.6 \\
\hline TOTAL & 98.89 & 100.02 & 99.61 & 96.57 & 99.74 & 99.34 & --- & --- \\
\hline
\end{tabular}


Table 6-8. Comparison of Calculated and Measured Compositions (wt\%)

\begin{tabular}{cccc}
\hline Component & $\begin{array}{c}\text { Calculated Glass } \\
\text { Composition }\end{array}$ & $\begin{array}{c}\text { Average Measured Melter } \\
\text { Feed Composition }\end{array}$ & $\begin{array}{c}\text { Average Measured Glass } \\
\text { Composition }\end{array}$ \\
\hline $\mathrm{Al}_{2} \mathrm{O}_{3}$ & 9.48 & 9.77 & 9.83 \\
\hline $\mathrm{B}_{2} \mathrm{O}_{3}$ & 5.12 & 5.00 & 4.90 \\
\hline $\mathrm{CaO}$ & 0.60 & 0.52 & 0.58 \\
\hline $\mathrm{Fe}_{2} \mathrm{O}_{3}$ & 11.09 & 11.08 & 10.59 \\
\hline $\mathrm{Li}_{2} \mathrm{O}$ & 5.12 & 4.90 & 4.80 \\
\hline $\mathrm{MgO}$ & 0.51 & 0.50 & 0.53 \\
\hline $\mathrm{MnO}_{2}$ & 3.83 & 3.61 & 3.83 \\
\hline $\mathrm{Na}_{2} \mathrm{O}$ & 11.53 & 11.60 & 11.93 \\
\hline $\mathrm{NiO}_{\mathrm{SiO}}$ & 1.31 & 1.26 & 1.23 \\
\hline
\end{tabular}

Table 6-9. Measured REDOX Data

\begin{tabular}{ccccc}
\hline Sample & Date & Time & $\mathbf{F e}^{2+} / \mathbf{F e}^{3+}$ & $\mathbf{F e}^{2+} / \sum \mathbf{F e}$ \\
\hline CEF1-GL-001 & $5 / 30 / 2013$ & $3: 35$ & 0.08 & 0.08 \\
\hline CEF1-GL-002 & $5 / 30 / 2013$ & $5: 35$ & 0.11 & 0.10 \\
\hline CEF1-GL-003 & $5 / 30 / 2013$ & $10: 50$ & 0.15 & 0.13 \\
\hline CEF1-GL-004 & $5 / 30 / 2013$ & $18: 28$ & 0.20 & 0.17 \\
\hline CEF1-GL-005 & $5 / 30 / 2013$ & $21: 40$ & 0.20 & 0.17 \\
\hline CEF1-GL-006 & $5 / 31 / 2013$ & $2: 12$ & 0.22 & 0.18 \\
\hline CEF1-GL-007 & $5 / 31 / 2013$ & $11: 17$ & 0.20 & 0.17 \\
\hline CEF1-GL-008 & $5 / 31 / 2013$ & $22: 17$ & 0.16 & 0.13 \\
\hline CEF1-GL-009 & $6 / 1 / 2013$ & $11: 11$ & 0.13 & 0.11 \\
\hline CEF1-GL-010 & $6 / 2 / 2013$ & $1: 35$ & 0.10 & 0.09 \\
\hline CEF1-GL-011 & $6 / 2 / 2013$ & $7: 20$ & 0.14 & 0.12 \\
\hline CEF1-GL-012 & $6 / 2 / 2013$ & $12: 10$ & 0.18 & 0.15 \\
\hline CEF1-GL-013 & $6 / 2 / 2013$ & $17: 11$ & 0.20 & 0.16 \\
\hline CEF1-GL-014 & $6 / 2 / 2013$ & $22: 08$ & 0.25 & 0.20 \\
\hline CEF1-GL-015 & $6 / 3 / 2013$ & $4: 36$ & 0.23 & 0.19 \\
\hline CEF1-GL-016 & $6 / 3 / 2013$ & $9: 53$ & 0.22 & 0.18 \\
\hline
\end{tabular}




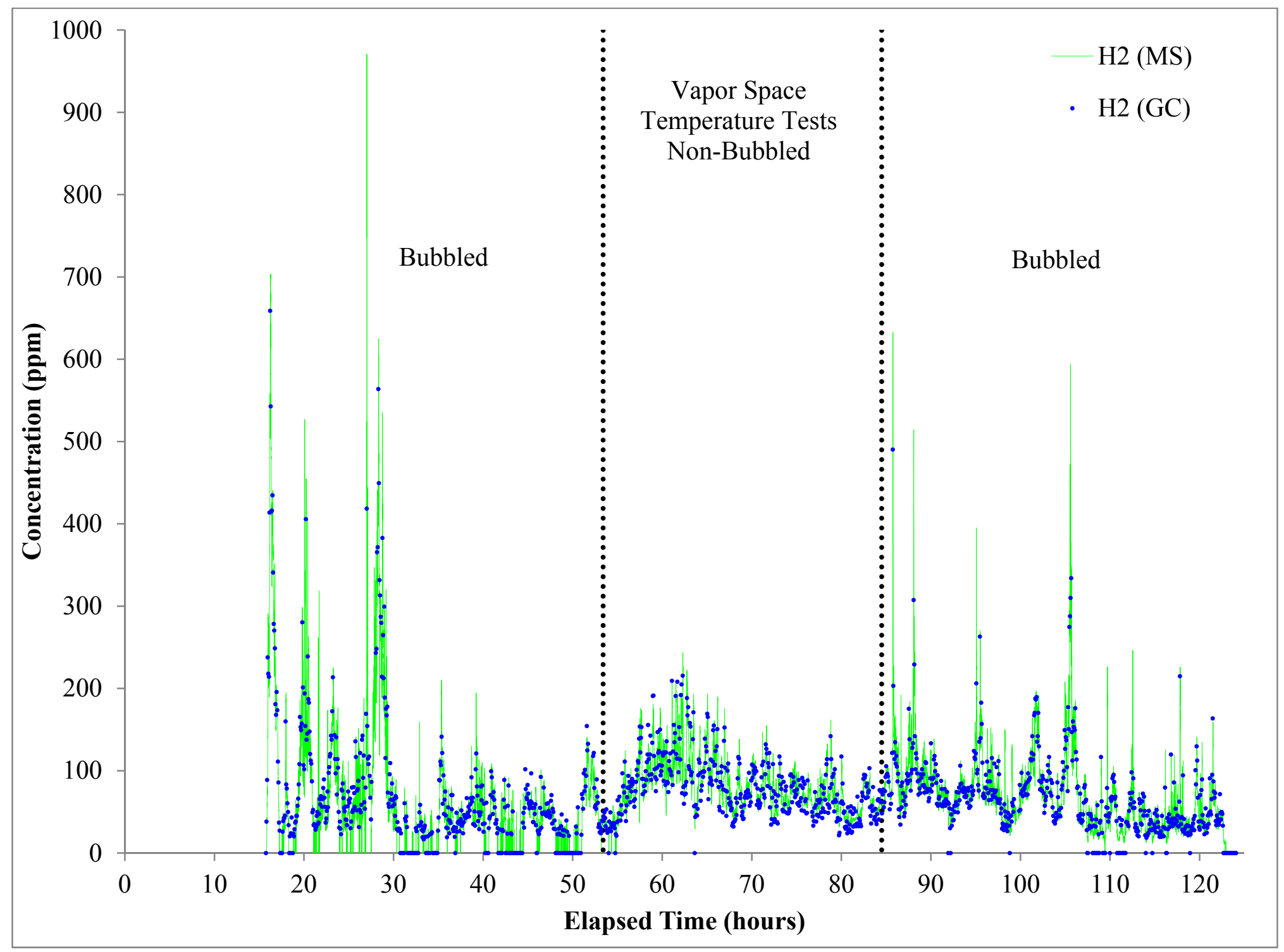

Figure 6-1. Hydrogen generation during bubbled and non-bubbled runs (Elapsed time=0 at 09:34 May 29, 2013). 


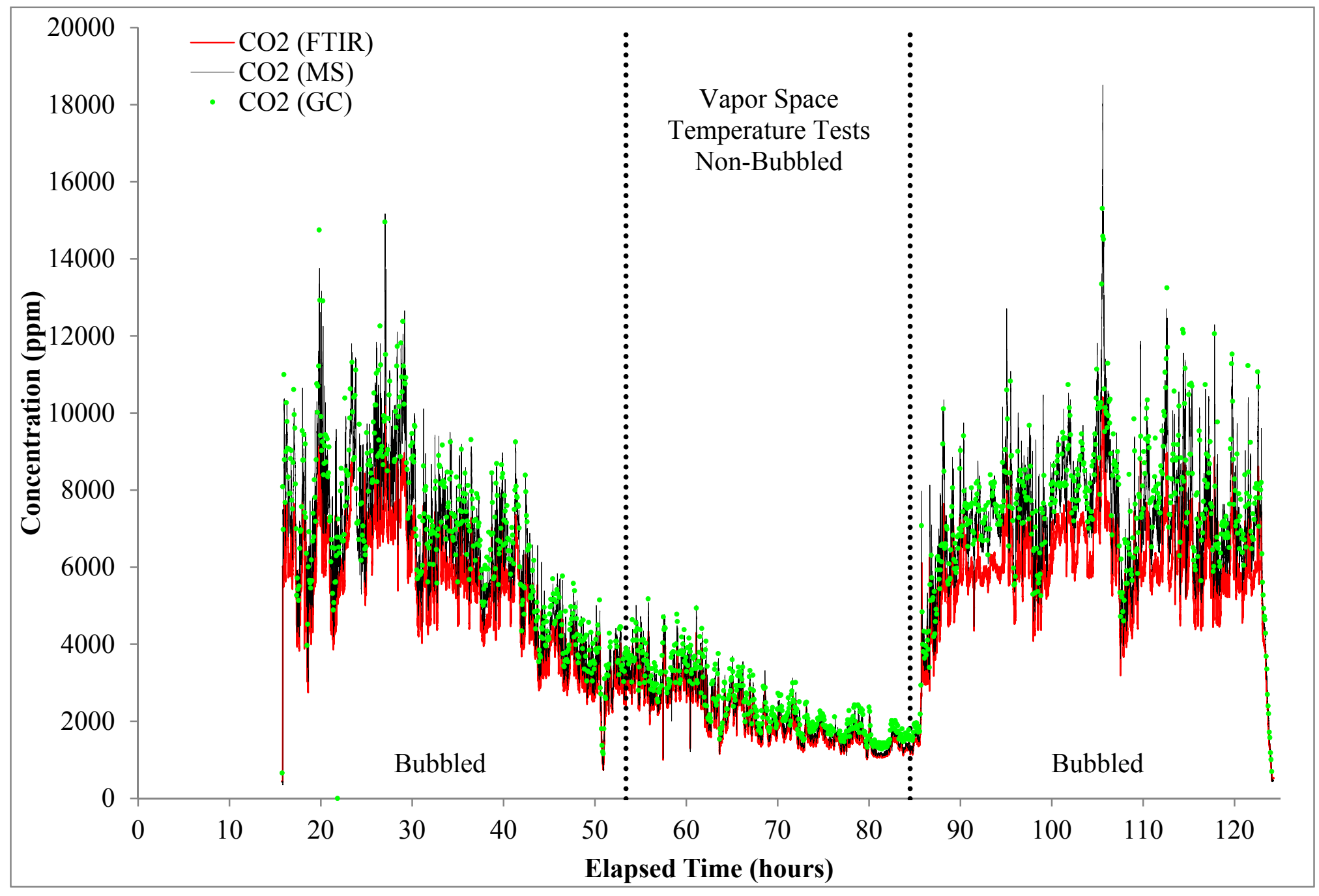

Figure 6-2. $\mathrm{CO}_{2}$ generation $($ Elapsed time $=0$ at 09:34 May 29, 2013). 


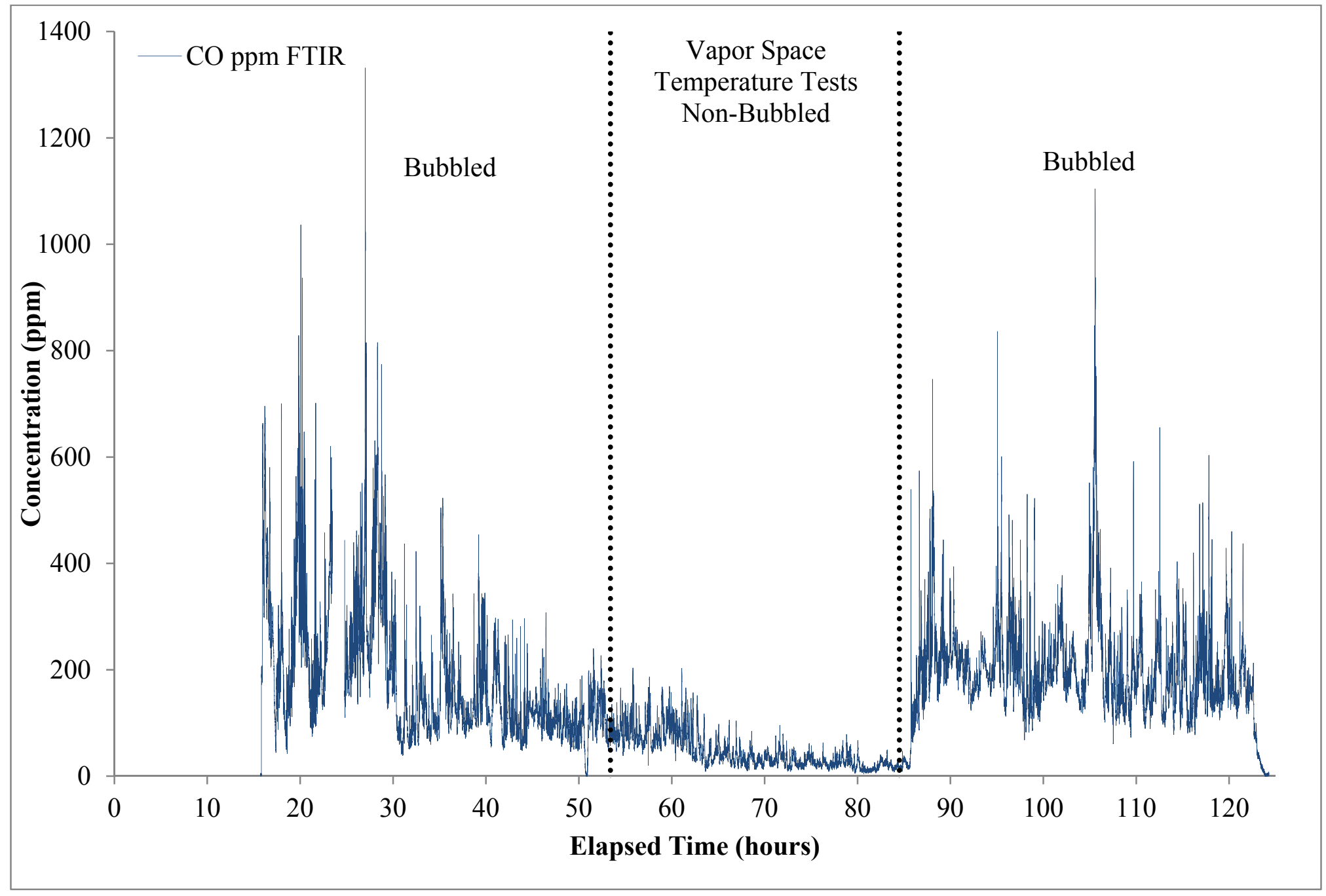

Figure 6-3. CO generation (Elapsed time=0 at 09:34 May 29, 2013). 


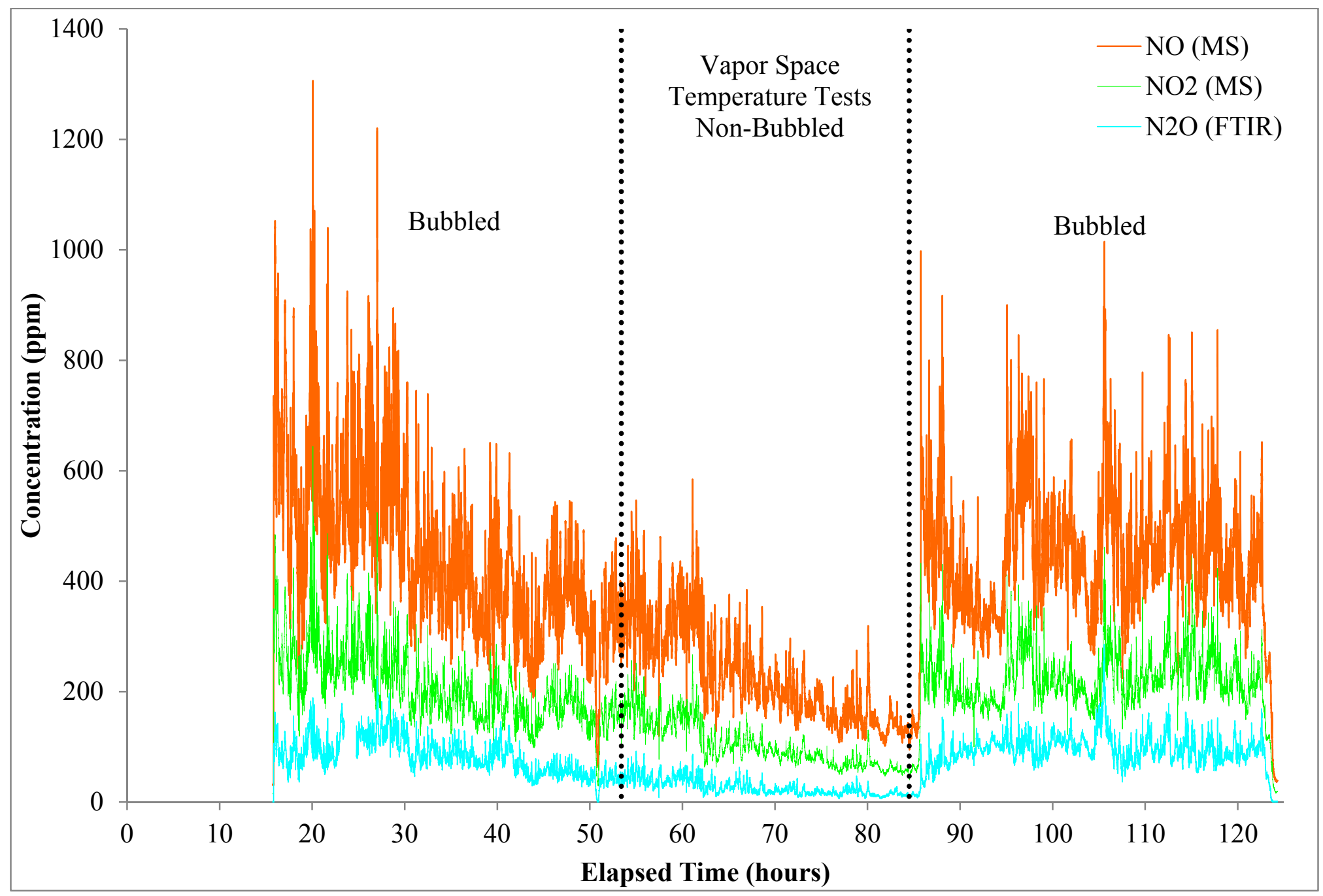

Figure 6-4. $\mathrm{NO}, \mathrm{NO}_{2}$ and $\mathrm{N}_{2} \mathrm{O}$ generation (Elapsed time=0 at 09:34 May 29, 2013). 


\subsection{References}

1. D.P. Lambert, M.E. Stone, J.D. Newell, D.R. Best, and J.R. Zamecnik, "Glycolic-Nitric Acid Flowsheet Demonstration of the DWPF Chemical Process Cell with Sludge and Supernate Simulants," Savannah River National Laboratory, Aiken, SC, SRNL-STI-2012-00018, Rev. 1, 2012.

2. T. Wagnon, "Defense Waste Processing Facility Alternate Reductant, Systems Engineering Evaluation,” Savannah River Remediation, Aiken, SC, G-AES-S-00003, 2011.

3. A.S. Choi, "Melter Off-Gas Flammability Assessment for DWPF Alternate Reductant Flowsheet Options," Savannah River National Laboratoy, Aiken, SC, SRNL-STI-2011-00321, 2011.

4. D.P. Lambert, B.R. Pickenheim, M.E. Stone, J.D. Newell, and D.R. Best, "Glycolic-Formic Acid Flowsheet Final Report for Downselect Decision," Savannah River National Laboratory, Aiken, SC, SRNL-STI-2010, 00523, Rev. 1, 2011.

5. T.L. Fellinger, D.P. Lambert, and M.E. Stone, "Technology Development Roadmap for NitricGlycolic Acid Flowsheet," Savannah River Remediation, Aiken, SC, SRR-STI-2012-00676, 2012.

6. E.W. Holtzscheiter, "Nitric-Glycolic Acid Flowsheet Melter Flammability Testing," Savannah River National Laboratory, Aiken, SC, HLW-DWPF-TTR-2013-0002, 2012.

7. F.C. Johnson, "Task Technical and Quality Assurance Plan for Alternative Reductant Melter Evaluation," Savannah River National Laboratory, Aiken, SC, SRL-RP-2012-00596, November 2012.

8. T.L. Fellinger, E.W. Holtzscheiter, J.M. Bricker, A. Samadi-Dezfouli, and M.E. Smith, "Selection of Melter Platform for Performing Melter Off Gas Flammability for the Alternate Reductant Project," Savannah River Remediation, Aiken, SC, SRR-WSE-2012-00132, 2012.

9. A.S. Choi, "2013 CEF Run - Phase I Data Analysis and Model Validation," Savannah River National Laboratory, Aiken, SC, SRNL-STI-2013-00705, Draft.

10. “786-A CEF Melter 2 Assembly,” Savannah River National Laboratory, Aiken, SC, Drawing No. EES-23248-R1-017, current revision.

11. “999-W CEF Melter 2 Assembly,” Savannah River National Laboratory, Aiken, SC, Drawing No. EES-23248-R1-001, current revision.

12. “999-W CEF Melter 2 Crucible Details," Savannah River National Laboratory, Aiken, SC, Drawing No. EES-23248-R4-010, current revision.

13. “999-W CEF Melter 2 Crucible Weldment," Savannah River National Laboratory, Aiken, SC, Drawing No. EES-23248-R3-003, current revision.

14. "999-W CEF Melter 2 Lid Subweldments and Details 3," Savannah River National Laboratory, Aiken, SC, Drawing No. EES-23248-R3-013, current revision. 
15. “999-W CEF Melter 2 Stand Weldment," Savannah River National Laboratory, Aiken, SC Drawing No. EES-23248-R3-002, current revision.

16. “999-W CEF Melter 2 Inspection Weldment," Savannah River National Laboratory, Aiken, SC, Drawing No. EES-23248-R3-004, current revision.

17. “999-W CEF Melter 2 Crucible Support Plate Weldment/Details," Savannah River National Laboratory, Aiken, SC, Drawing No. EES-23248-R3-005, current revision.

18. “786-A CEF Melter Lid Subweldments \& Details 2," Savannah River National Laboratory, Aiken, SC, Drawing No. EES-23248-R3-006, current revision.

19. “786-A CEF Melter 2 Lid Weldment," Savannah River National Laboratory, Aiken, SC, Drawing No. EES-23248-R3-007, current revision.

20. “999-W CEF Melter 2 Miscellaneous Details," Savannah River National Laboratory, Aiken, SC, Drawing No. EES-23248-R4-008, current revision.

21. “999-W CEF Melter 2 Insulation Details," Savannah River National Laboratory, Aiken, SC, Drawing No. EES-23248-R4-009, current revision.

22. “999-W CEF Melter 2 Stand \& Related Details," Savannah River National Laboratory, Aiken, SC, Drawing No. EES-23248-R4-011, current revision.

23. “786-A CEF Melter Clamp \& Bubbler Assembly, Weldment \& Details," Savannah River National Laboratory, Aiken, SC, Drawing No. EES-23248-R1-012, current revision.

24. "999-W CEF Melter 2 Lid Subweldments \& Details 1," Savannah River National Laboratory, Aiken, SC, Drawing No. EES-23248-R3-014, current revision.

25. "CEF Melter: Lid Heater Stuffing Box Details," Savannah River National Laboratory, Aiken, SC Drawing No. EES-23248-R4-015, current revision.

26. “786-A CEF Melter Detail Sheet Detail," Savannah River National Laboratory, Aiken, SC Drawing No. EES-23248-R3-016, current revision.

27. J. McIntosh, "Equipment Electrical Safety Evaluation," Savannah River National Laboratory, Aiken, SC, E-ESR-W-00005, Rev. 1, 2013.

28. J.T. Coughlin, "CEF Melter Dimensional Characterization," Savannah River National Laboratory, Aiken, SC, Job Folder 23248, 2013.

29. W.L. Daugherty, “Creep Life Assessment of Inconel 690 CEF Melter 2 Vessel," Savannah River National Laboratory, Aiken, SC, SRNL-L4400-2012-00030, 2012.

30. J. Coughlin, "CEF 2 Tension Rod Structural Calculation, Rev. B," Savannah River National Laboratory, Aiken, SC, Job-23248, 2013.

31. “CEF Melter C4 Camera Weldments," Savannah River National Laboratory, Aiken, SC, Drawing No. 009706, current revision. 
32. “CEF Melter: C4 Camera Weldment Components Detail," Savannah River National Laboratory, Aiken, SC Drawing No. 009611, current revision.

33. "CEF Melter: C4 Camera Assembly Components Detail," Savannah River National Laboratory, Aiken, SC, Drawing No. 009704, current revision.

34. "CEF Melter: C4 Camera Lens Cassette Assembly and Details," Savannah River National Laboratory, Aiken, SC, Drawing No. 009705, current revision.

35. "CEF Melter: CEF Concentric Convection Cooled Camera (C4 Camera)," Savannah River National Laboratory, Aiken, SC, Drawing No. 009610, current revision.

36. D.P. Lambert, "Batching Recipe: Nitric/Formic Acid Flowsheet Melter Feed," Savannah River National Laboratory, Aiken, SC, SRNL-L3100-2013-00021, 2013.

37. D.C. Koopman, A.I. Fernandez, and B.R. Pickenheim, "Preliminary Evaluations of Two Proposed Stoichiometric Acid Equations," Savannah River National Laboratory, Aiken, SC, SRNL-L3100-2009-00146, 2009.

38. M.E. Stone, "Feed Preparation for Alternative Reductant Melter Testing," Savannah River National Laboratory, Aiken, SC, SRNL-L3100-2013-00109, 2013.

39. M.E. Stone, "Acceptance of Harrell Batch SB6i Formic Acid Flowsheet SRAT Product," Savannah River National Laboratory, Aiken, SC, SRNL-L3100-2013-00055, 2013.

40. "Weight Percent Solids Determination Using a Furnace or Oven," Savannah River National Laboratory, Aiken, SC, ITS-0078, current revision.

41. "Dissolution of Glass, Sludge and Slurry Samples Using $\mathrm{Na}_{2} \mathrm{O}_{2} / \mathrm{NaOH} / \mathrm{HCl}$," Savannah River National Laboratory, Aiken, SC, ITS-0040, current revision.

42. "Lithium Metaborate Fusion Preparation," Savannah River National Laboratory, Aiken, SC, ITS0071, current revision.

43. "Lithium Tetraborate Fusion Preparation," Savannah River National Laboratory, Aiken, SC, ITS0070, current revision.

44. "Sample Dissolution Using Potassium Hydroxide Fusion," Savannah River National Laboratory, Aiken, SC, ITS-0035, current revision.

45. "Aqua Regia Dissolutions of Passivated Hydride Materals," Savannah River National Laboratory, Aiken, SC, ITS-WI-0036, current revision.

46. "Inductively Coupled Plasma-Atomic Emission Spectrometer Agilent 730 ES," Savannah River National Laboratory, Aiken, SC, ITS-0079, current revision.

47. "Anion Analysis Using the Dionex DX-500 and ICS-5000 Ion Chromatograph," Savannah River National Laboratory, Aiken, SC, ITS-0027, current revision.

48. "Operation of OI Analytical 1030 W Carbon Analyzer: Wet Oxidation Method," Savannah River National Laboratory, Aiken, SC, ADS-1209, current revision. 
49. "Determining $\mathrm{Fe}^{2+} / \mathrm{Fe}^{3+}$ and $\mathrm{Fe}^{2+} / \mathrm{Fe}$ (Total) Using Uv Vis Spectrometer," Savannah River National Laboratory, Aiken, SC, ITS-0042, current revision.

50. F.C. Johnson, "Cold Cap Evaluation Furnace (CEF) Testing Readiness Assessment," Savannah River National Laboratory, Aiken, SC, SRNL-L3100-2013-00071, May 2013.

51. F.C. Johnson and D.H. Miller, "Nitric-Formic Acid Flowsheet Melter Flammability Testing: 2013 Phase 1 CEF Run R\&D Directions," Savannah River National Laboratory, Aiken, SC SRNL-L3100-2013-00045, May 2013.

52. F.C. Johnson, “Alternate Reductant Cold Cap Evaluation Furnace (CEF) Phase I Data," Savannah River National Laboratory, Aiken, SC, SRNL-L3100-2013-00189, 2013.

53. A.S. Choi, M.E. Smith, K.R. Crow, M.R. Baron, G.F. Rabon, S.L. Goudelock, and A.M. Wehner, "Summary of Campaigns Sgm-9 and Sgm-10 of the DWPF Scale Glass Melter," Savannah River Laboratory, Aiken, SC, DPST-88-626, 1988. 
SRNL-STI-2014-00005

Revision 0

Appendix A. Supplementary Figures and Tables 


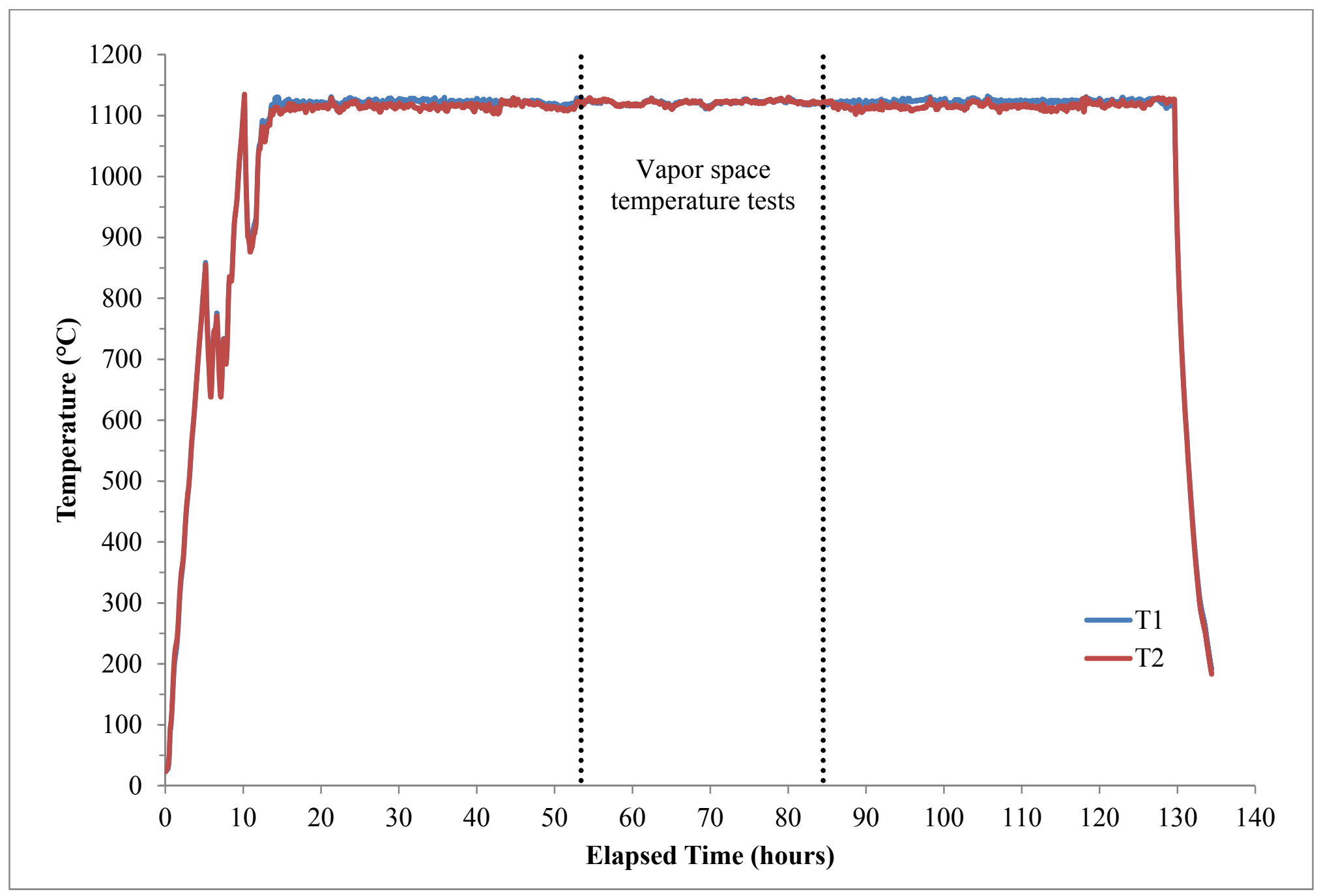

Figure A-1. Melter bottom thermocouple temperatures (Elapsed time $=0$ at 09:34 May 29, 2013). 


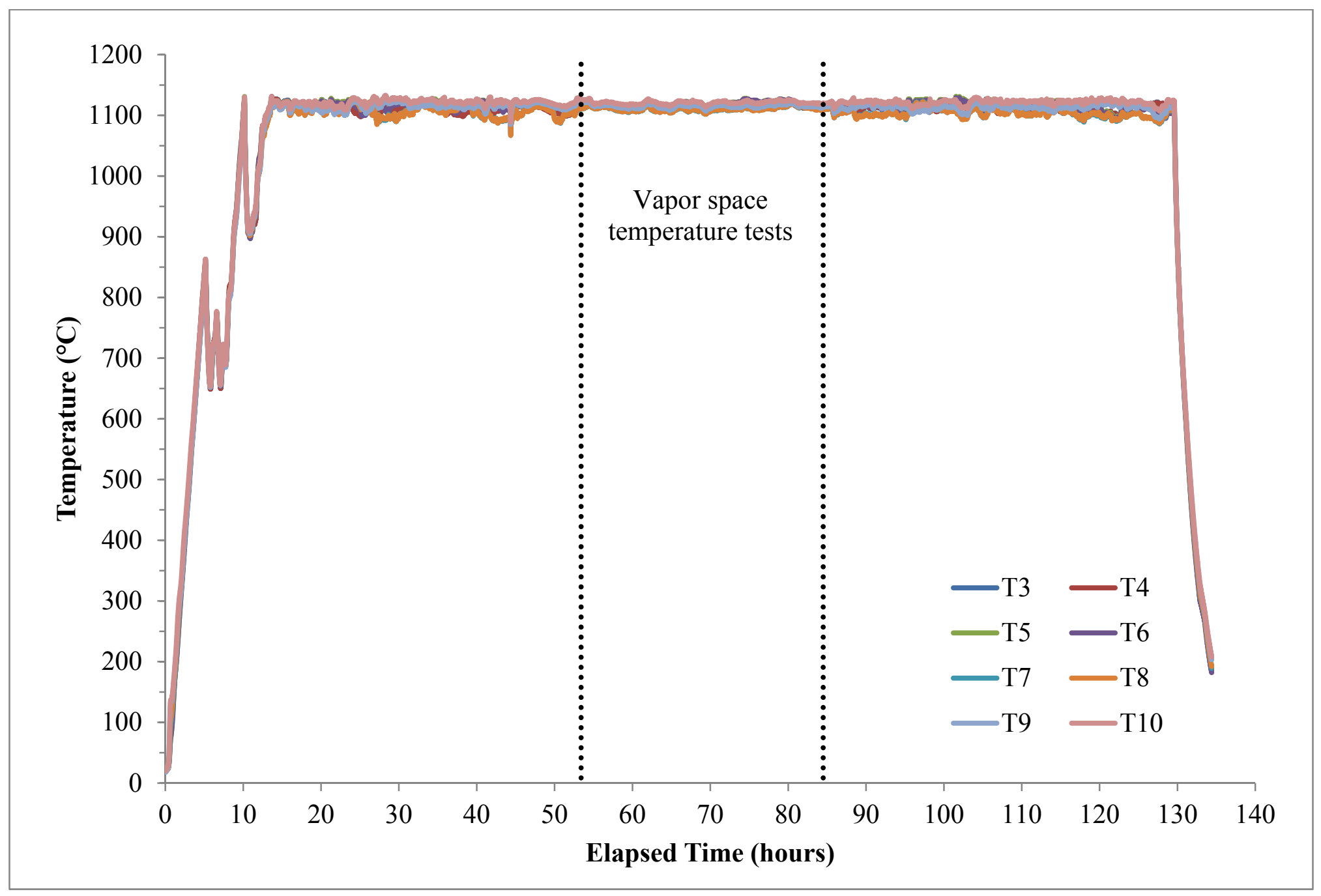

Figure A-2. Melter side thermocouple temperatures (Elapsed time=0 at 09:34 May 29, 2013). 


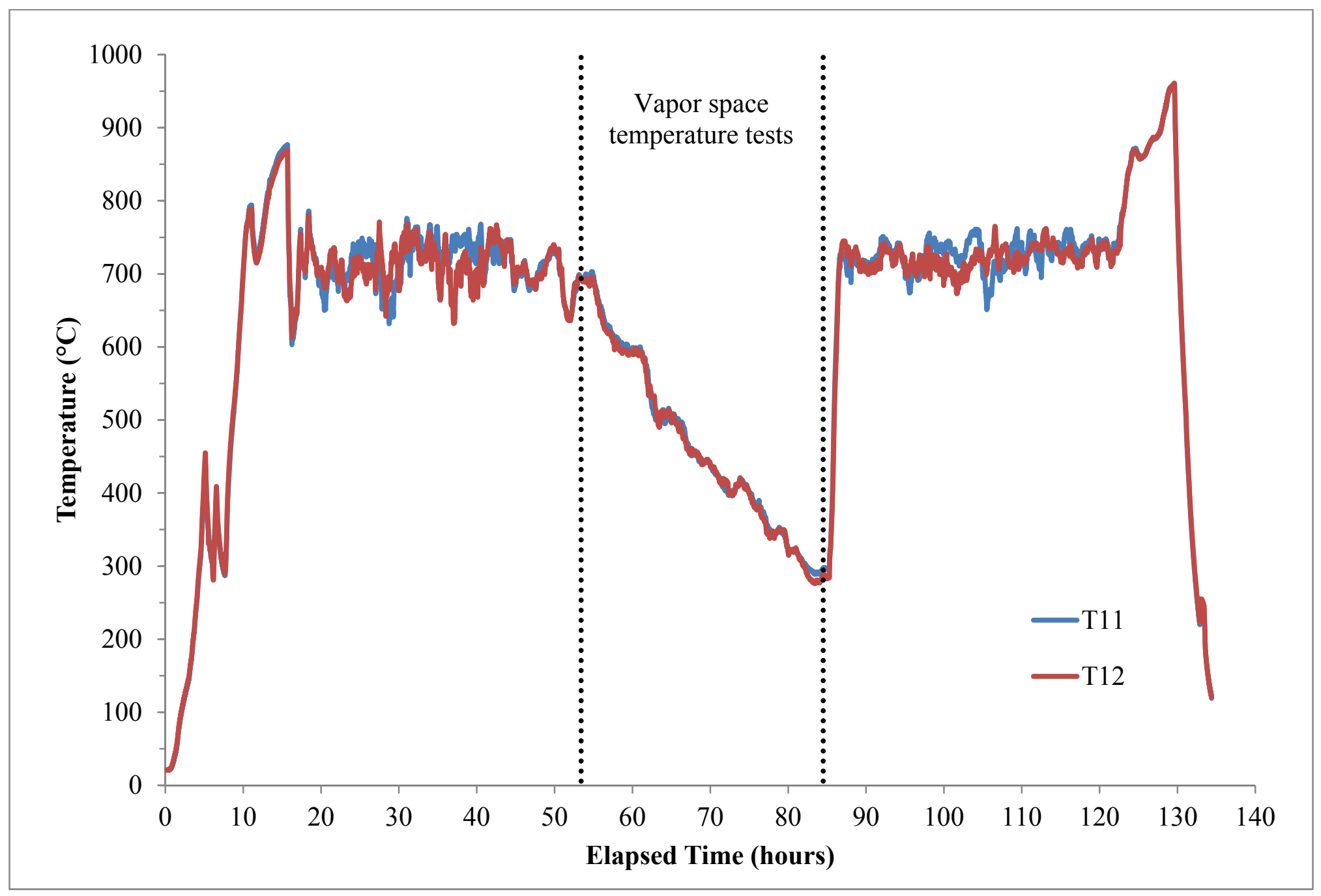

Figure A-3. Vapor space thermocouple temperatures (Elapsed time=0 at 09:34 May 29, 2013). 


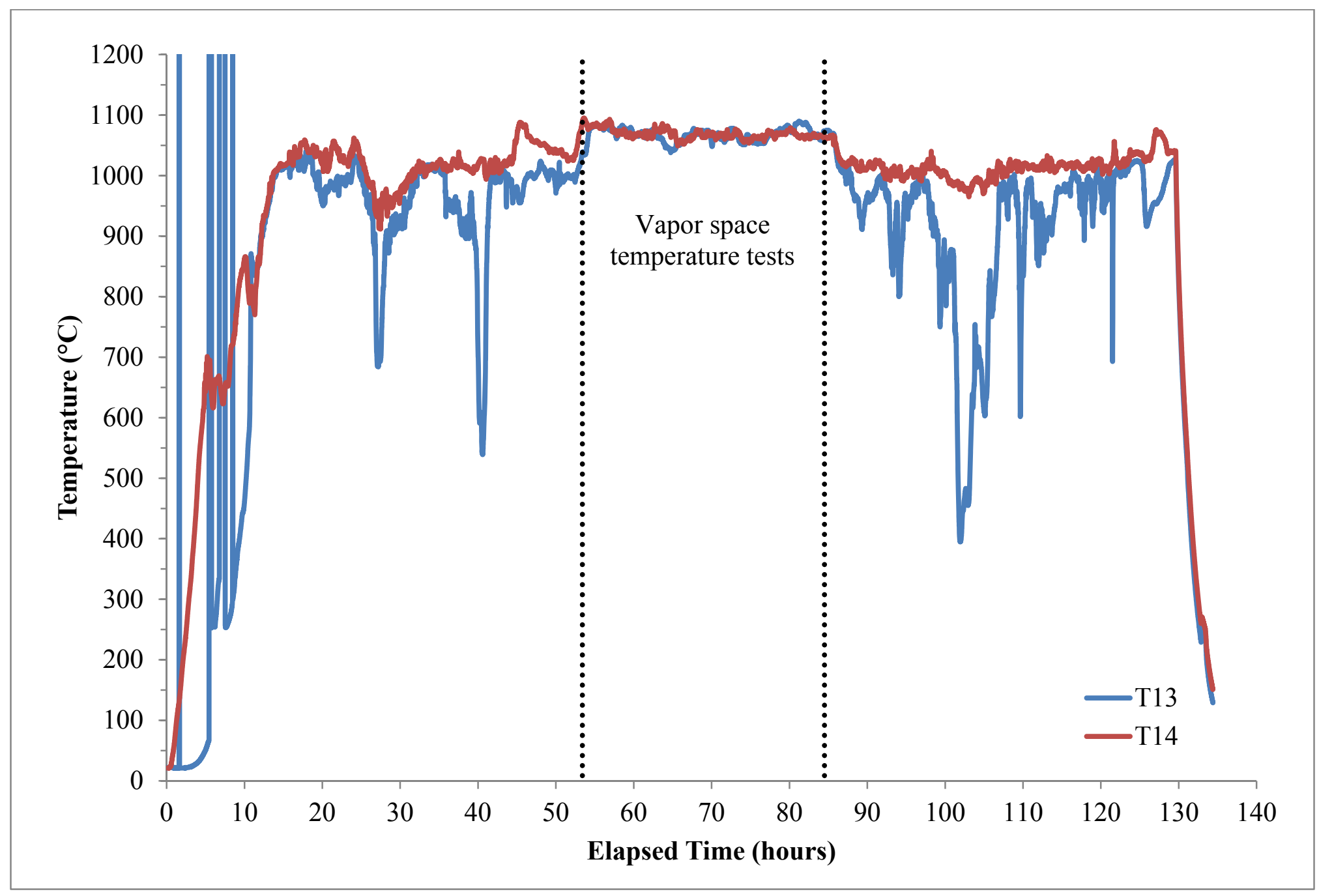

Figure A-4. Glass pool thermocouple temperatures (Elapsed time=0 at 09:34 May 29, 2013). 


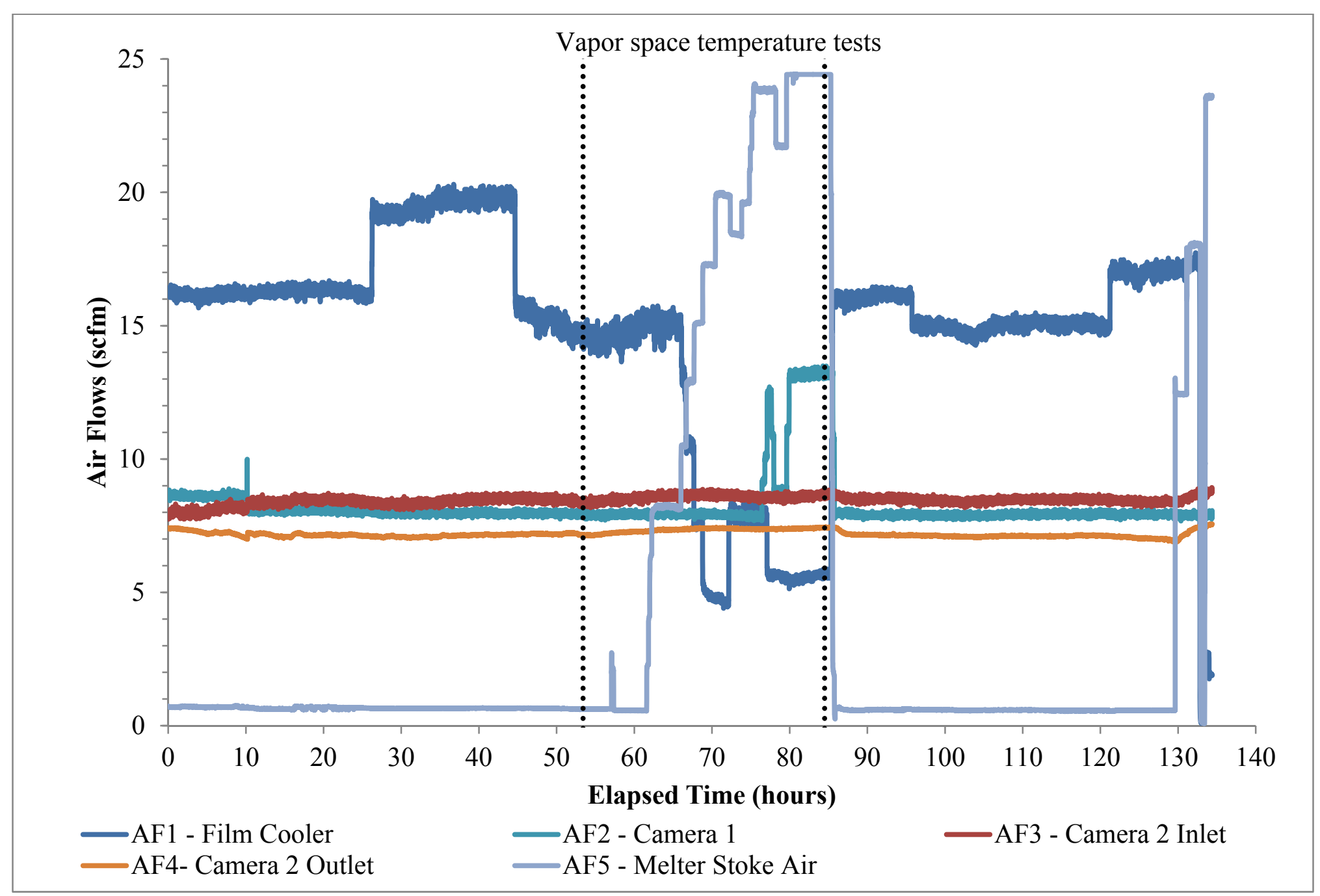

Figure A-5. Air flows (Elapsed time=0 at 09:34 May 29, 2013). 


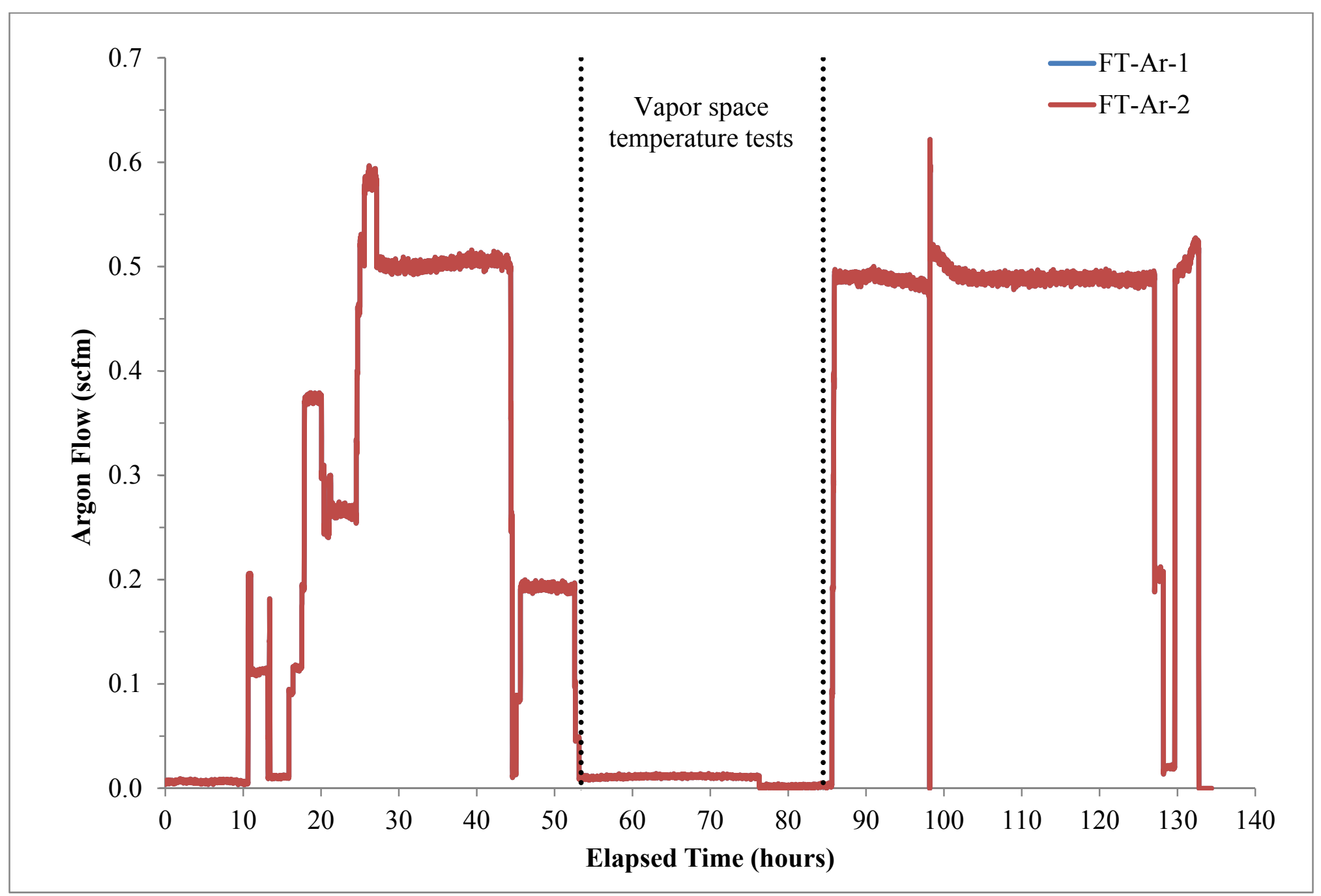

Figure A-6. Argon bubbler flows (Elapsed time=0 at 09:34 May 29, 2013). 


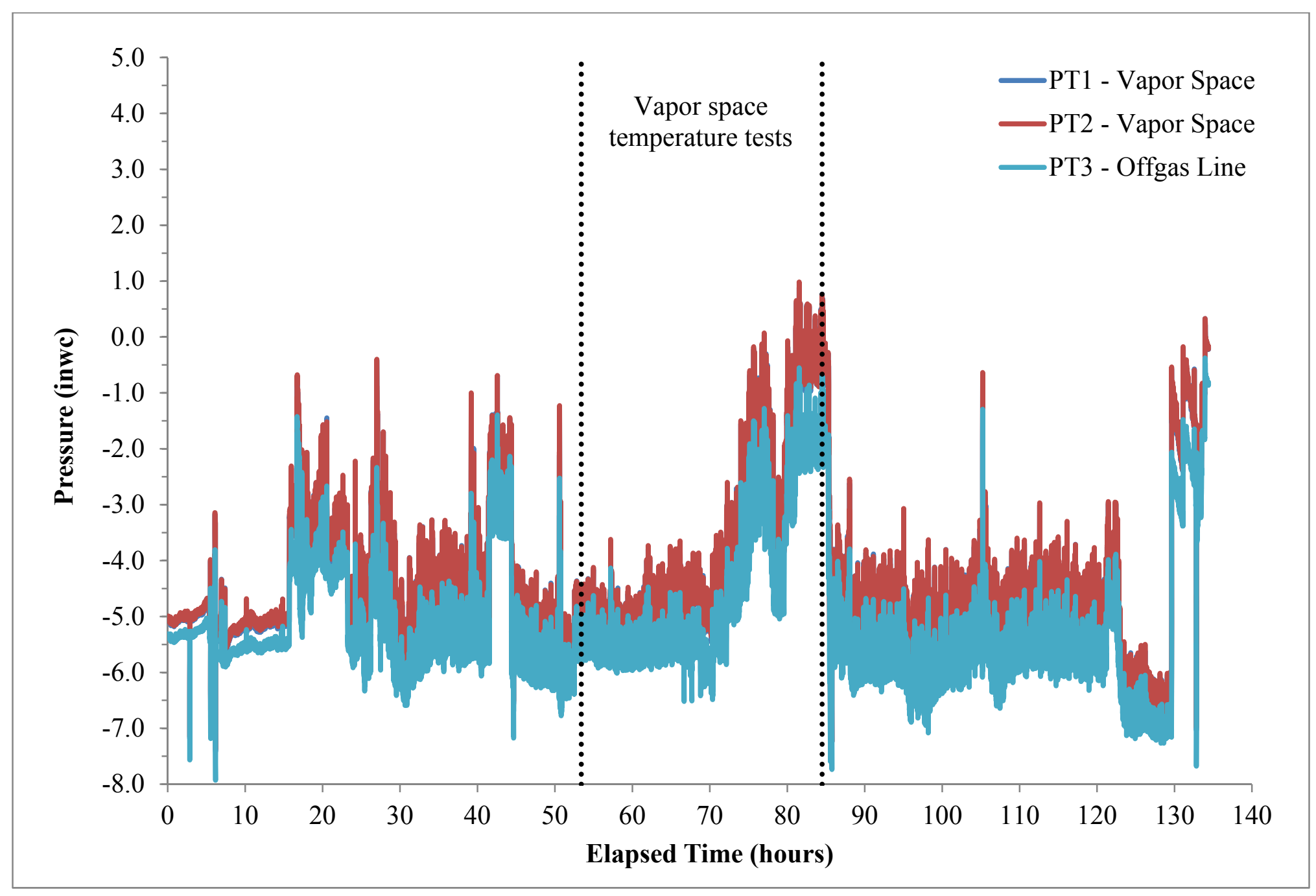

Figure A-7. Vapor space and off-gas line pressures (Elapsed time=0 at 09:34 May 29, 2013). 


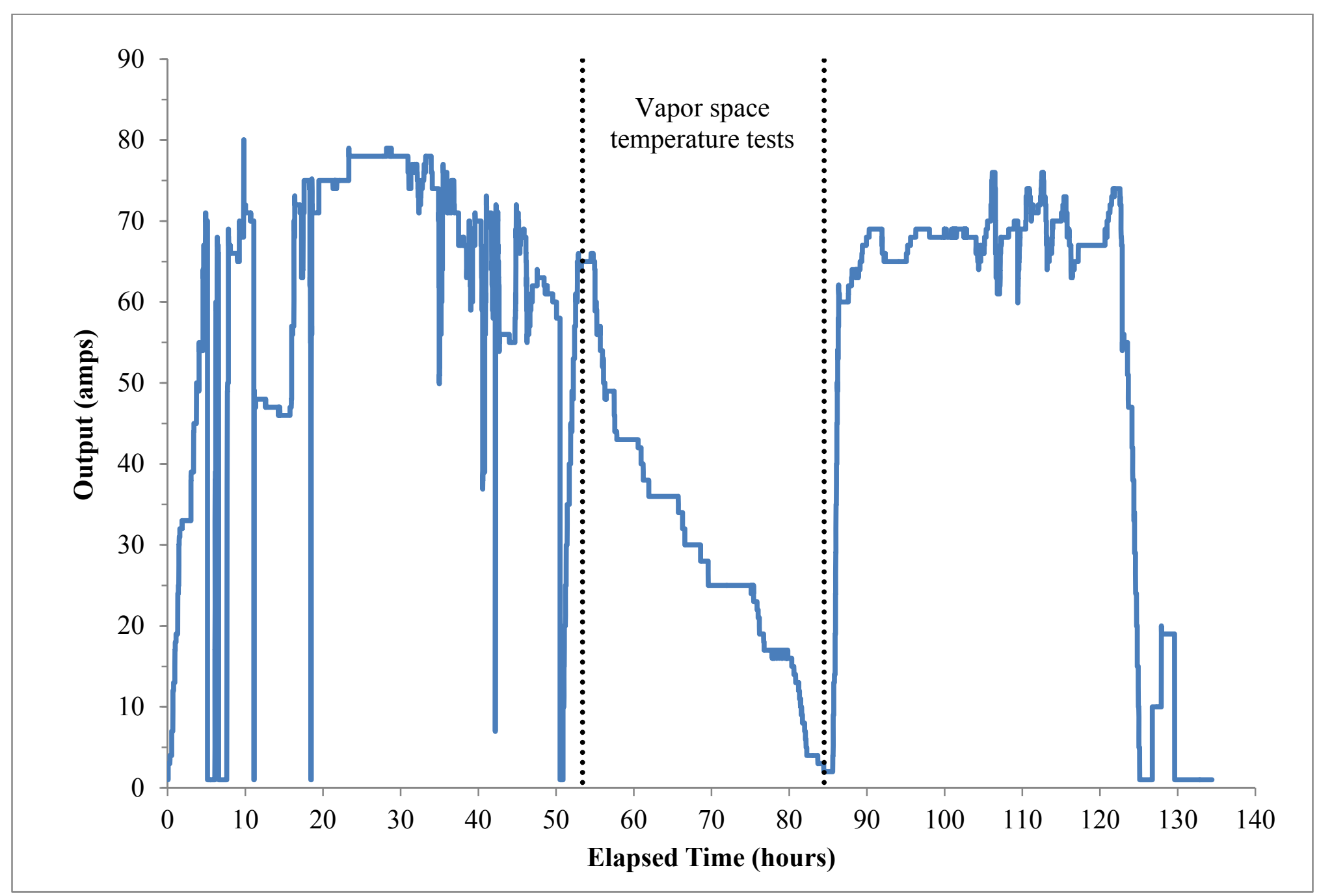

Figure A-8. Vapor space heater output (Elapsed time=0 at 09:34 May 29, 2013). 


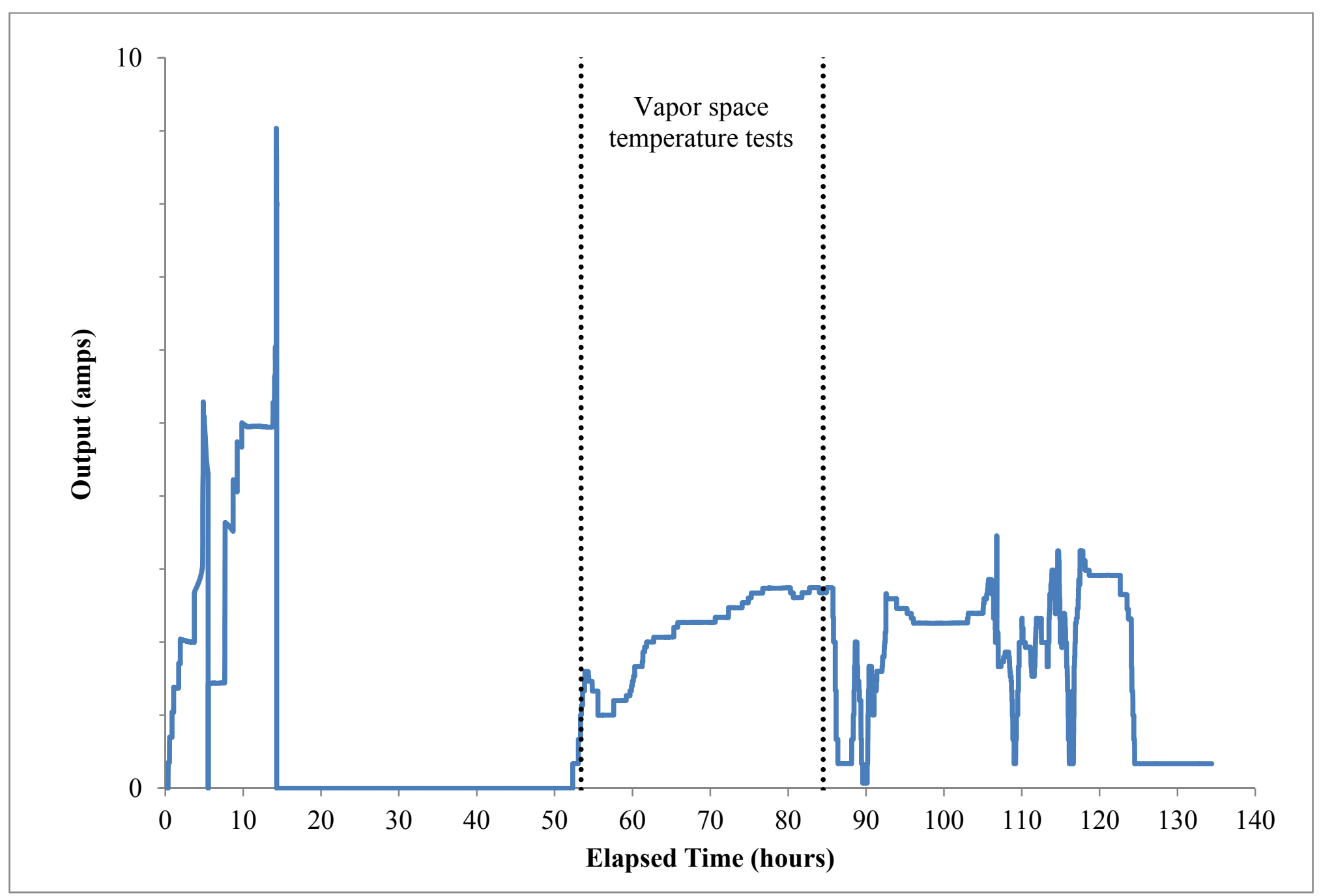

Figure A-9. Auxiliary pour tube heater output (Elapsed time=0 at 09:34 May 29, 2013). 


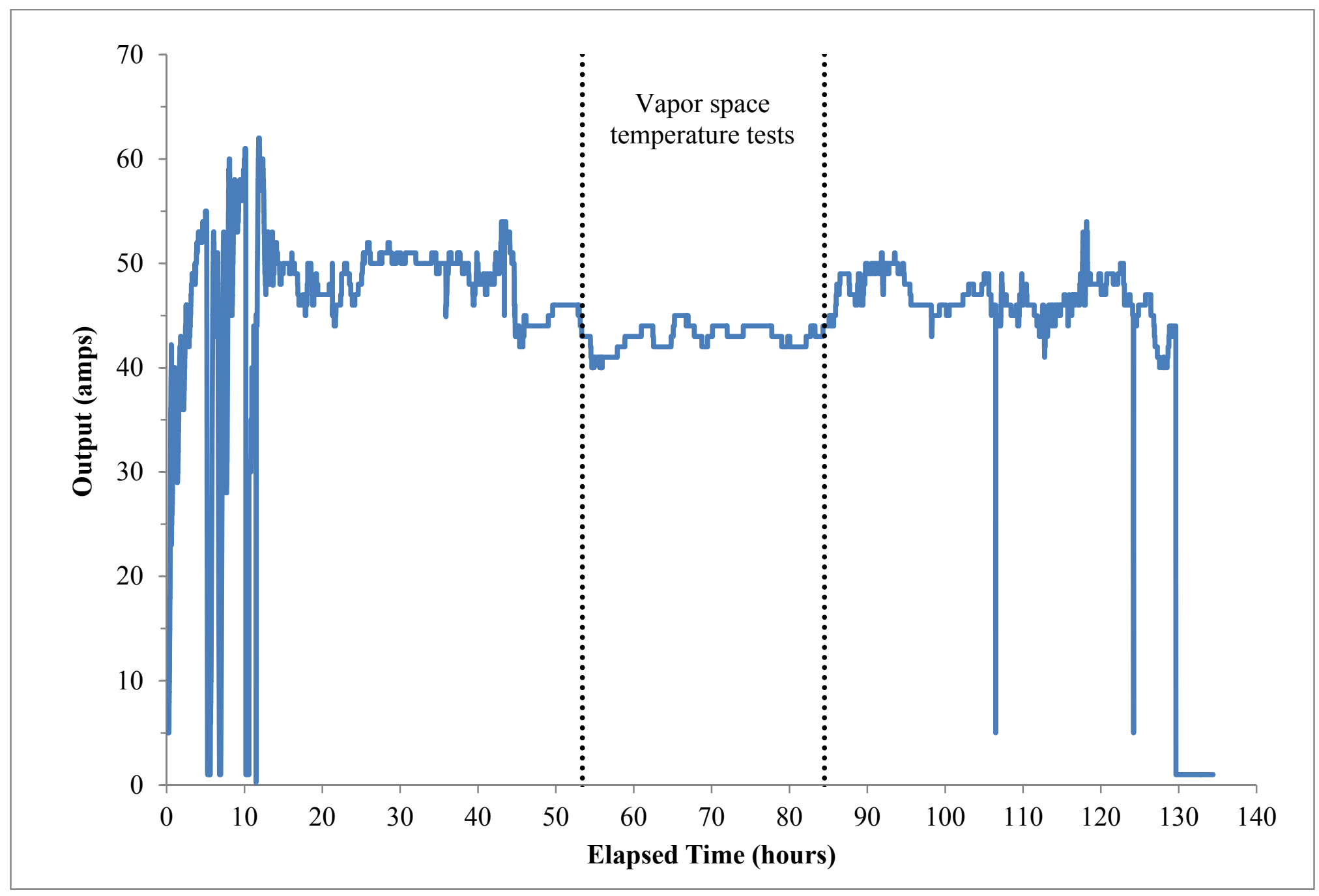

Figure A-10. Bottom heater output (Elapsed time=0 at 09:34 May 29, 2013). 


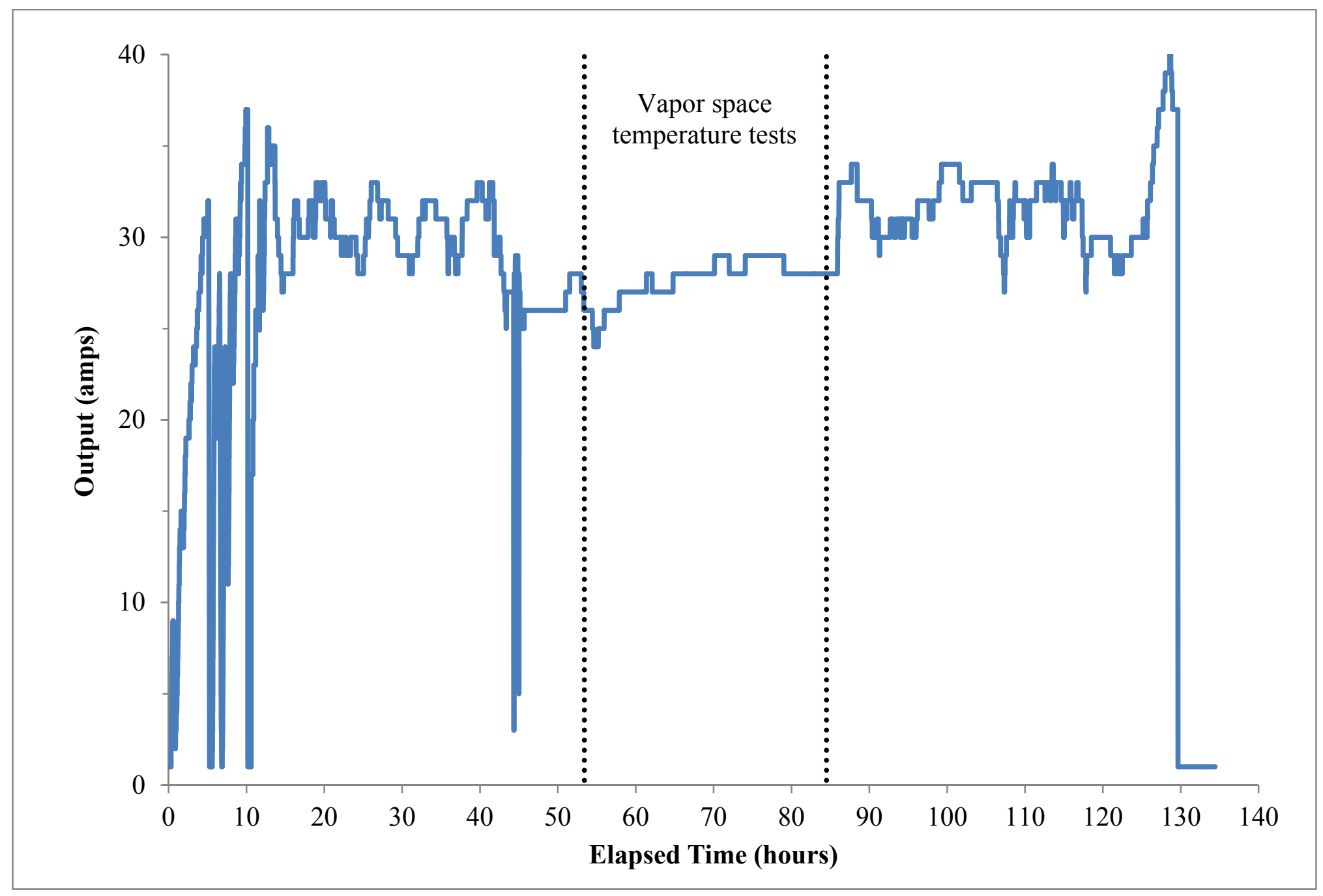

Figure A-11. Side heater output (Elapsed time=0 at 09:34 May 29, 2013). 


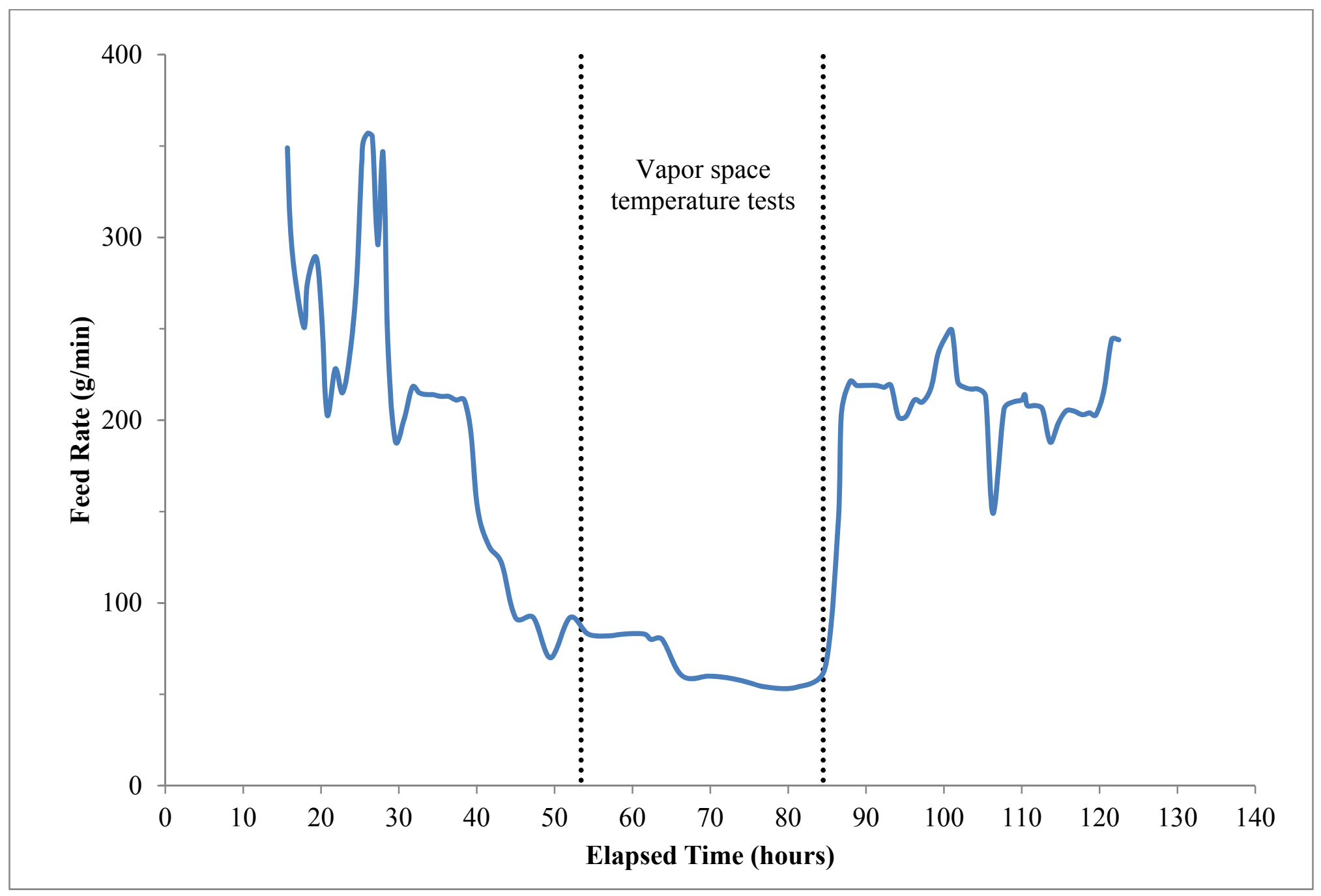

Figure A-12. Feed rate (Elapsed time=0 at 09:34 May 29, 2013). 
Table A-1. ICP-AES Analysis of Feed (elemental wt $\%$ calcined $1100^{\circ} \mathrm{C}$ )

\begin{tabular}{|c|c|c|c|c|c|c|c|c|c|c|c|c|c|}
\hline Sample ID & Lab ID & Al & B & $\mathbf{B a}$ & $\mathbf{C a}$ & $\mathrm{Ce}$ & $\mathbf{C r}$ & $\mathbf{C u}$ & $\mathbf{F e}$ & $\mathbf{K}$ & $\mathbf{L i}$ & Mg & \\
\hline CEF1-F-059 (A) & $13-0919$ & 5.09 & 1.65 & 0.045 & 0.360 & 0.060 & 0.063 & 0.060 & 7.90 & 0.125 & 2.29 & 0.297 & \\
\hline CEF1-F-059 (B) & 13-0919 & 5.05 & 1.62 & 0.046 & 0.365 & 0.060 & 0.065 & 0.094 & 7.60 & 0.129 & 2.28 & 0.301 & \\
\hline CEF1-F-060 (A) & $13-0920$ & 5.35 & 1.56 & 0.049 & 0.376 & 0.068 & 0.068 & 0.091 & 7.96 & 0.133 & 2.20 & 0.309 & \\
\hline CEF1-F-060 (B) & $13-0920$ & 5.40 & 1.55 & 0.049 & 0.384 & 0.068 & 0.068 & 0.103 & 8.18 & 0.133 & 2.22 & 0.311 & \\
\hline CEF1-F-061 (A) & $13-0921$ & 5.16 & 1.56 & 0.047 & 0.376 & 0.067 & 0.066 & 0.082 & 7.77 & 0.127 & 2.26 & 0.310 & \\
\hline CEF1-F-061 (B) & $13-0921$ & 5.11 & 1.53 & 0.047 & 0.386 & 0.068 & 0.067 & 0.081 & 7.69 & 0.130 & 2.23 & 0.312 & \\
\hline CEF1-F-062 (A) & $13-0922$ & 4.99 & 1.54 & 0.045 & 0.361 & 0.063 & 0.064 & 0.065 & 7.47 & 0.129 & 2.28 & 0.296 & \\
\hline CEF1-F-062 (B) & $13-0922$ & 5.03 & 1.56 & 0.045 & 0.362 & 0.064 & 0.063 & 0.054 & 7.57 & 0.129 & 2.31 & 0.296 & \\
\hline CEF1-F-063 (A) & $13-0923$ & 5.21 & 1.49 & 0.047 & 0.385 & 0.065 & 0.064 & 0.048 & 7.72 & 0.131 & 2.30 & 0.307 & \\
\hline CEF1-F-063 (B) & $13-0923$ & 5.25 & 1.47 & 0.046 & 0.384 & 0.065 & 0.064 & 0.060 & 7.64 & 0.129 & 2.29 & 0.306 & \\
\hline CEF1-F-064 (A) & $13-0924$ & 5.11 & 1.54 & 0.046 & 0.367 & 0.060 & 0.064 & 0.062 & 7.66 & 0.128 & 2.31 & 0.298 & \\
\hline CEF1-F-064 (B) & $13-0924$ & 5.10 & 1.53 & 0.046 & 0.370 & 0.061 & 0.065 & 0.069 & 7.65 & 0.129 & 2.31 & 0.300 & \\
\hline CEF1-F-065 (A) & $13-0925$ & 5.24 & 1.55 & 0.046 & 0.361 & 0.063 & 0.066 & 0.068 & 7.82 & 0.131 & 2.31 & 0.300 & \\
\hline CEF1-F-065 (B) & $13-0925$ & 5.25 & 1.56 & 0.047 & 0.368 & 0.064 & 0.066 & 0.072 & 7.83 & 0.136 & 2.30 & 0.303 & \\
\hline Sample ID & Lab ID & Mn & $\mathbf{N a}$ & $\mathrm{Ni}$ & $\mathbf{P}$ & $\mathbf{P b}$ & Pd & $\mathbf{S}$ & Sn & $\mathbf{S i}$ & $\mathbf{T i}$ & $\mathbf{Z n}$ & $\mathbf{Z r}$ \\
\hline CEF1-F-059 (A) & 13-0919 & 2.33 & 8.73 & 1.00 & $<0.100$ & $<0.100$ & $<0.100$ & 0.098 & 0.028 & 23.4 & 0.020 & 0.041 & 0.096 \\
\hline CEF1-F-059 (B) & 13-0919 & 2.26 & 8.59 & 1.00 & $<0.100$ & $<0.100$ & $<0.100$ & 0.098 & 0.029 & 23.3 & 0.020 & 0.042 & 0.097 \\
\hline CEF1-F-060 (A) & $13-0920$ & 2.38 & 8.64 & 1.06 & $<0.100$ & $<0.100$ & $<0.100$ & 0.088 & 0.031 & 22.7 & 0.022 & 0.044 & 0.104 \\
\hline CEF1-F-060 (B) & $13-0920$ & 2.37 & 8.60 & 1.05 & $<0.100$ & $<0.100$ & $<0.100$ & 0.090 & 0.030 & 22.7 & 0.021 & 0.044 & 0.104 \\
\hline CEF1-F-061 (A) & $13-0921$ & 2.34 & 8.64 & 1.01 & $<0.100$ & $<0.100$ & $<0.100$ & 0.094 & 0.030 & 23.2 & 0.021 & 0.041 & 0.100 \\
\hline CEF1-F-061 (B) & $13-0921$ & 2.33 & 8.70 & 1.01 & $<0.100$ & $<0.100$ & $<0.100$ & 0.101 & 0.030 & 22.7 & 0.021 & 0.042 & 0.101 \\
\hline CEF1-F-062 (A) & $13-0922$ & 2.22 & 8.55 & 0.977 & $<0.100$ & $<0.100$ & $<0.100$ & 0.095 & 0.029 & 23.2 & 0.020 & 0.042 & 0.098 \\
\hline CEF1-F-062 (B) & $13-0922$ & 2.21 & 8.63 & 0.946 & $<0.100$ & $<0.100$ & $<0.100$ & 0.094 & 0.029 & 23.3 & 0.021 & 0.041 & 0.098 \\
\hline CEF1-F-063 (A) & 13-0923 & 2.30 & 8.66 & 0.971 & $<0.100$ & $<0.100$ & $<0.100$ & 0.097 & 0.029 & 23.0 & 0.020 & 0.042 & 0.099 \\
\hline CEF1-F-063 (B) & $13-0923$ & 2.29 & 8.61 & 0.970 & $<0.100$ & $<0.100$ & $<0.100$ & 0.096 & 0.029 & 22.3 & 0.020 & 0.041 & 0.099 \\
\hline CEF1-F-064 (A) & $13-0924$ & 2.20 & 8.47 & 0.963 & $<0.100$ & $<0.100$ & $<0.100$ & 0.101 & 0.030 & 22.5 & 0.020 & 0.041 & 0.097 \\
\hline CEF1-F-064 (B) & $13-0924$ & 2.23 & 8.50 & 0.973 & $<0.100$ & $<0.100$ & $<0.100$ & 0.097 & 0.030 & 23.2 & 0.020 & 0.041 & 0.098 \\
\hline CEF1-F-065 (A) & $13-0925$ & 2.24 & 8.45 & 0.982 & $<0.100$ & $<0.100$ & $<0.100$ & 0.101 & 0.031 & 23.5 & 0.020 & 0.042 & 0.100 \\
\hline CEF1-F-065 (B) & $13-0925$ & 2.25 & 8.54 & 0.986 & $<0.100$ & $<0.100$ & $<0.100$ & 0.099 & 0.030 & 23.5 & 0.021 & 0.043 & 0.102 \\
\hline
\end{tabular}


Table A-2. IC Analysis of Feed (mg/kg)

\begin{tabular}{|c|c|c|c|c|c|c|c|c|c|}
\hline Sample ID & Lab ID & $\mathbf{F}$ & Cl & $\mathrm{NO}_{2}$ & $\mathrm{NO}_{3}$ & $\mathrm{SO}_{4}$ & $\mathrm{C}_{2} \mathrm{O}_{4}$ & $\mathrm{HCO}_{2}$ & $\mathrm{PO}_{4}$ \\
\hline CEF1-F-059 (A) & 13-0919 & $<500$ & 315 & $<500$ & 17200 & 402 & $<500$ & 44600 & $<500$ \\
\hline CEF1-F-059 (B) & 13-0919 & $<500$ & 307 & $<500$ & 17200 & 488 & $<500$ & 44600 & $<500$ \\
\hline CEF1-F-060 (A) & $13-0920$ & $<500$ & 314 & $<500$ & 17700 & 539 & $<500$ & 46000 & $<500$ \\
\hline CEF1-F-060 (B) & $13-0920$ & $<500$ & 318 & $<500$ & 17700 & 598 & $<500$ & 46300 & $<500$ \\
\hline CEF1-F-061 (A) & 13-0921 & $<500$ & 313 & $<500$ & 17900 & 610 & $<500$ & 44900 & $<500$ \\
\hline CEF1-F-061 (B) & 13-0921 & $<500$ & 315 & $<500$ & 17900 & 656 & $<500$ & 45000 & $<500$ \\
\hline CEF1-F-062 (A) & $13-0922$ & $<500$ & 312 & $<500$ & 17900 & 701 & $<500$ & 45800 & $<500$ \\
\hline CEF1-F-062 (B) & $13-0922$ & $<500$ & 312 & $<500$ & 17500 & 702 & $<500$ & 45700 & $<500$ \\
\hline CEF1-F-063 (A) & $13-0923$ & $<500$ & 310 & $<500$ & 17800 & 689 & $<500$ & 45600 & $<500$ \\
\hline CEF1-F-063 (B) & $13-0923$ & $<500$ & 305 & $<500$ & 17600 & 713 & $<500$ & 45900 & $<500$ \\
\hline CEF1-F-064 (A) & $13-0924$ & $<500$ & 307 & $<500$ & 17900 & 728 & $<500$ & 45300 & $<500$ \\
\hline CEF1-F-064 (B) & $13-0924$ & $<500$ & 303 & $<500$ & 17400 & 744 & $<500$ & 45200 & $<500$ \\
\hline CEF1-F-065 (A) & $13-0925$ & $<500$ & 321 & $<500$ & 17100 & 731 & $<500$ & 47200 & $<500$ \\
\hline CEF1-F-065 (B) & $13-0925$ & $<500$ & 308 & $<500$ & 17100 & 770 & $<500$ & 47200 & $<500$ \\
\hline
\end{tabular}


Table A-3. Feed Solids and Density

\begin{tabular}{|c|c|c|c|c|c|c|c|c|}
\hline Sample & Lab ID & Total Solids & $\begin{array}{l}\text { Ins oluble } \\
\text { Solids }\end{array}$ & $\begin{array}{l}\text { Wt \% } \\
\text { Calcined }\end{array}$ & $\begin{array}{l}\text { Soluble } \\
\text { Solids }\end{array}$ & pH & $\begin{array}{l}\text { Density } \\
\text { (g/cc) }\end{array}$ & $\begin{array}{c}\text { Density } \\
\text { Supernate }(\mathrm{g} / \mathrm{cc})\end{array}$ \\
\hline CEF1-F-059 (A) & 13-0919 & $42.4 \%$ & $34.3 \%$ & $34.8 \%$ & $53.42 \%$ & \multirow{2}{*}{6.01} & 1.3263 & 1.08079 \\
\hline CEF1-F-059 (B) & 13-0919 & $42.4 \%$ & $34.3 \%$ & $34.8 \%$ & $53.33 \%$ & & 1.3262 & 1.08079 \\
\hline CEF1-F-060 (A) & $13-0920$ & $41.6 \%$ & $33.2 \%$ & $33.8 \%$ & $50.99 \%$ & \multirow{2}{*}{5.99} & 1.3160 & 1.08243 \\
\hline CEF1-F-060 (B) & $13-0920$ & $41.7 \%$ & $32.9 \%$ & $33.8 \%$ & $51.16 \%$ & & 1.3161 & 1.08243 \\
\hline CEF1-F-061 (A) & $13-0921$ & $42.1 \%$ & $33.5 \%$ & $34.4 \%$ & $52.40 \%$ & \multirow{2}{*}{5.97} & 1.3073 & 1.08177 \\
\hline CEF1-F-061 (B) & $13-0921$ & $41.9 \%$ & $33.8 \%$ & $34.2 \%$ & $52.02 \%$ & & 1.3072 & 1.08177 \\
\hline CEF1-F-062 (A) & $13-0922$ & $42.9 \%$ & $34.6 \%$ & $35.1 \%$ & $54.04 \%$ & \multirow{2}{*}{5.99} & 1.3145 & 1.08211 \\
\hline CEF1-F-062 (B) & $13-0922$ & $42.8 \%$ & $34.6 \%$ & $35.0 \%$ & $53.79 \%$ & & 1.3147 & 1.08210 \\
\hline CEF1-F-063 (A) & $13-0923$ & $42.1 \%$ & $33.2 \%$ & $34.3 \%$ & $52.15 \%$ & \multirow{2}{*}{5.99} & 1.3126 & 1.08315 \\
\hline CEF1-F-063 (B) & $13-0923$ & $41.9 \%$ & $33.4 \%$ & $34.1 \%$ & $51.82 \%$ & & 1.3125 & 1.08314 \\
\hline CEF1-F-064 (A) & $13-0924$ & $42.3 \%$ & $33.8 \%$ & $34.6 \%$ & $52.91 \%$ & \multirow{2}{*}{5.99} & 1.3115 & 1.08217 \\
\hline CEF1-F-064 (B) & $13-0924$ & $42.3 \%$ & $33.5 \%$ & $34.5 \%$ & $52.72 \%$ & & 1.3114 & 1.08214 \\
\hline CEF1-F-065 (A) & $13-0925$ & $42.0 \%$ & $33.7 \%$ & $34.2 \%$ & $51.99 \%$ & \multirow{2}{*}{6.02} & 1.3154 & 1.08131 \\
\hline CEF1-F-065 (B) & $13-0925$ & $41.7 \%$ & $33.7 \%$ & $33.8 \%$ & $51.12 \%$ & & 1.3154 & 1.08129 \\
\hline
\end{tabular}

Table A-4. Feed Carbon Content

\begin{tabular}{ccccc}
\hline Sample ID & Lab ID & $\begin{array}{c}\text { Total Carbon } \\
\mathbf{u g} / \mathbf{m L}\end{array}$ & $\begin{array}{c}\text { Organic } \\
\text { Carbon ug/mL }\end{array}$ & $\begin{array}{c}\text { Inorganic } \\
\text { Carbon ug/mL }\end{array}$ \\
\hline CEF1-F-059 & 300305064 & $<15100$ & 15000 & $<80$ \\
\hline CEF1-F-060 & 300305065 & $<14500$ & 14400 & $<80$ \\
\hline CEF1-F-061 & 300305066 & $<15700$ & 15600 & $<80$ \\
\hline CEF1-F-062 & 300305067 & $<15000$ & 14900 & $<80$ \\
\hline CEF1-F-063 & 300305068 & $<15400$ & 15300 & $<80$ \\
\hline CEF1-F-064 & 300305069 & $<15200$ & 15100 & $<80$ \\
\hline CEF1-F-065 & 300305070 & $<17000$ & 16900 & $<80$ \\
\hline
\end{tabular}

Note: Since inorganic carbon levels are below detection limits, the total carbon value must be reported as "<" since total carbon is the sum of organic and inorganic carbon. 
Table A-5. Condensate Cations Set 1 (mg/L)

\begin{tabular}{|c|c|c|c|c|c|c|c|c|c|c|c|c|c|c|c|c|c|c|c|c|}
\hline Sample ID & ab ID & Al & B & Ba & $\mathbf{C a}$ & $\mathrm{Ce}$ & $\mathrm{Cr}$ & $\mathbf{C u}$ & $\mathrm{Fe}$ & $\mathbf{K}$ & $\mathbf{L i}$ & Mg & Mn & $\mathrm{Na}$ & $\mathbf{N i}$ & $\mathbf{P b}$ & $\mathbf{S i}$ & Ti & $\mathbf{Z n}$ & $\mathbf{Z r}$ \\
\hline CEF1-C-023 (A) & 13-0891 & 0.363 & 13.6 & $<0.010$ & 7.24 & $<0.010$ & 0.282 & $<0.010$ & 0.028 & 1.75 & 1.26 & 0.596 & $<0.010$ & 63.7 & $<0.010$ & $<0.010$ & 4.58 & $<0.010$ & $<0.010$ & $<0.010$ \\
\hline CEF1-C-023 (B) & 13-0891 & 0.396 & 13.9 & $<0.010$ & 7.48 & $<0.010$ & 0.289 & $<0.010$ & 0.028 & 1.79 & 1.29 & 0.615 & $<0.010$ & 62.3 & $<0.010$ & $<0.010$ & 4.68 & $<0.010$ & $<0.010$ & $<0.010$ \\
\hline CEF1-C-036 (A) & $13-0892$ & 0.435 & 17.6 & $<0.010$ & 7.70 & $<0.010$ & 0.316 & $<0.010$ & 0.029 & 1.93 & 1.64 & 0.682 & $<0.010$ & 76.0 & $<0.010$ & $<0.010$ & 4.84 & $<0.010$ & $<0.010$ & $<0.010$ \\
\hline CEF1-C-036 (B) & $13-0892$ & 0.421 & 18.0 & $<0.010$ & 7.72 & $<0.010$ & 0.315 & $<0.010$ & 0.029 & 1.94 & 1.65 & 0.683 & $<0.010$ & 75.8 & $<0.010$ & $<0.010$ & 4.86 & $<0.010$ & $<0.010$ & $<0.010$ \\
\hline CEF1-C-037 (A) & $13-0893$ & 0.409 & 17.1 & $<0.010$ & 7.49 & $<0.010$ & 0.307 & $<0.010$ & 0.028 & 1.90 & 1.61 & 0.659 & $<0.010$ & 76.7 & $<0.010$ & $<0.010$ & 4.70 & $<0.010$ & $<0.010$ & $<0.010$ \\
\hline CEF1-C-037 (B) & $13-0893$ & 0.389 & 17.6 & $<0.010$ & 7.59 & $<0.010$ & 0.311 & $<0.010$ & 0.028 & 1.93 & 1.63 & 0.670 & $<0.010$ & 75.2 & $<0.010$ & $<0.010$ & 4.77 & $<0.010$ & & $<0.010$ \\
\hline CEF1-C-038 (A) & -0894 & 0.367 & 17.4 & $<0.010$ & 7.67 & $<0.010$ & 0.316 & $<0.010$ & 0.028 & 1.96 & 1.66 & 0.687 & $<0.010$ & 78.5 & $<0$. & $<0.010$ & 4.96 & $<0.010$ & & $<0.010$ \\
\hline CEF1-C-0 & 4 & & 17.4 & $<0.0$ & 7.59 & $<0.010$ & & $<0$. & 0.1 & 1.94 & 1.64 & & 010 & 79.9 & $<0$. & $<0.010$ & 4.89 & $<0.010$ & & $<0.010$ \\
\hline CEF1-C-04 & 13-0895 & 0.439 & 18.3 & $<0.010$ & 7.69 & $<0.010$ & 0.316 & $<0.010$ & 0.028 & 1.98 & 1.69 & 0.699 & $<0.010$ & 80.4 & $<0.010$ & $<0.010$ & 4.94 & $<0.010$ & $<0$. & $<0.010$ \\
\hline CEF1 & 13-0895 & 0.429 & 18.9 & $<0.010$ & 7.86 & $<0.010$ & 0.322 & $<0.010$ & 0.028 & 2.03 & 1.72 & 0.715 & $<0.010$ & 80.1 & $<0.010$ & $<0.010$ & 5.02 & $<0.010$ & $<0.010$ & $<0.010$ \\
\hline CEF1 & -0896 & 0.507 & 18.6 & $<0.010$ & 7.72 & $<0.010$ & 0.317 & $<0.010$ & 0.028 & 2.01 & 1.70 & 0.704 & $<0.010$ & 79.5 & $<0.010$ & $<0.010$ & 5.02 & $<0.010$ & $<0.010$ & $<0.010$ \\
\hline CEF 1 & $13-0896$ & 0.504 & 18.4 & $<0.010$ & 7.73 & $<0.010$ & 0.319 & $<0.010$ & 0.028 & 2.01 & 1.70 & 0.704 & $<0.010$ & 78.8 & $<0.010$ & $<0.010$ & 5.02 & $<0.010$ & $<0.010$ & $<0.010$ \\
\hline CEF1- & $13-0897$ & 0.430 & 18.1 & $<0.010$ & 7.63 & $<0.010$ & 0.312 & $<0.010$ & 0.028 & 1.98 & 1.67 & 0.695 & $<0.010$ & 79.4 & $<0.010$ & $<0.010$ & 4.98 & $<0.010$ & $<0.010$ & $<0.010$ \\
\hline CEF1- & 13-0897 & 0.416 & 18.3 & $<0.010$ & 7.68 & $<0.010$ & 0.313 & $<0.010$ & 0.028 & 2.00 & 1.69 & 0.700 & $<0.010$ & 79.4 & $<0.010$ & $<0.010$ & 5.04 & $<0.010$ & $<0.010$ & $<0.010$ \\
\hline CEF1- & $3-0898$ & 0.490 & 18.8 & $<0.010$ & 7.70 & $<0.010$ & 0.316 & $<0.010$ & 0.029 & 2.05 & 1.70 & 0.708 & $<0.010$ & 81.7 & $<0.010$ & $<0.010$ & 5.16 & $<0.010$ & $<0.010$ & $<0.010$ \\
\hline CEF1-C-044 (B) & 13-0898 & 0.481 & 19.0 & $<0.010$ & 7.73 & $<0.010$ & 0.315 & $<0.010$ & 0.028 & 2.07 & 1.70 & 0.705 & $<0.010$ & 82.4 & $<0.010$ & $<0.010$ & 5.13 & $<0.010$ & $<0.010$ & $<0.010$ \\
\hline CEF1-C-048 (A) & 13-0899 & 0.451 & 19.2 & $<0.010$ & 7.92 & $<0.010$ & 0.322 & $<0.010$ & 0.029 & 2.11 & 1.78 & 0.741 & $<0.010$ & 82.6 & $<0.010$ & $<0.010$ & 5.75 & $<0.010$ & $<0.010$ & $<0.010$ \\
\hline CEF1-C-048 (B) & 13-0899 & 0.443 & 19.5 & $<0.010$ & 7.98 & $<0.010$ & 0.328 & $<0.010$ & 0.028 & 2.11 & 1.78 & 0.749 & $<0.010$ & 81.1 & $<0.010$ & $<0.010$ & 5.79 & $<0.010$ & $<0.010$ & $<0.010$ \\
\hline CEF1-C-049 (A) & 13-0900 & 0.427 & 19.1 & $<0.010$ & 7.78 & $<0.010$ & 0.321 & $<0.010$ & 0.029 & 2.09 & 1.76 & 0.737 & $<0.010$ & 84.2 & $<0.010$ & $<0.010$ & 5.95 & $<0.010$ & $<0.010$ & $<0.010$ \\
\hline CEF1-C-049 (B) & $13-0900$ & 0.421 & 19.4 & $<0.010$ & 7.85 & $<0.010$ & 0.326 & $<0.010$ & 0.029 & 2.10 & 1.77 & 0.741 & $<0.010$ & 84.0 & $<0.010$ & $<0.010$ & 5.97 & $<0.010$ & $<0.010$ & $<0.010$ \\
\hline CEF1-C-050 (A) & 13-0901 & 0.486 & 19.3 & $<0.010$ & 7.65 & $<0.010$ & 0.318 & $<0.010$ & 0.029 & 2.10 & 1.75 & 0.727 & $<0.010$ & 84.9 & $<0.010$ & $<0.010$ & 5.93 & $<0.010$ & $<0.010$ & $<0.010$ \\
\hline CEF1-C-050 (B) & 13-0901 & 0.484 & 18.8 & $<0.010$ & 7.72 & $<0.010$ & 0.317 & $<0.010$ & 0.030 & 2.11 & 1.75 & 0.728 & $<0.010$ & 84.4 & $<0.010$ & $<0.010$ & 5.95 & $<0.010$ & $<0.010$ & $<0.010$ \\
\hline CEF1-C-058 (A) & 13-0902 & 0.484 & 19.2 & $<0.010$ & 7.82 & $<0.010$ & 0.323 & $<0.010$ & 0.029 & 2.14 & 1.80 & 0.759 & $<0.010$ & 84.3 & $<0.010$ & $<0.010$ & 6.50 & $<0.010$ & $<0.010$ & $<0.010$ \\
\hline CEF1-C-058 (B) & 13-0902 & 0.503 & 19.3 & $<0.010$ & 7.81 & $<0.010$ & 0.322 & $<0.010$ & 0.029 & 2.14 & 1.80 & 0.757 & $<0.010$ & 85.2 & $<0.0$ & $<0$. & 6.52 & $<0.010$ & $<0$. & $<0.010$ \\
\hline & 13-0903 & 0.459 & 19.2 & $<0.010$ & 7.69 & $<0.010$ & 0.317 & $<0.010$ & 0.029 & 2.11 & 1.77 & 0.746 & $<0.010$ & 85.6 & $<0.010$ & $<0.010$ & 6.54 & $<0.010$ & $<0.010$ & $<0.010$ \\
\hline CEF1-C-059 (B) & 13-0903 & 0.491 & 19.0 & $<0.010$ & 7.74 & $<0.010$ & 0.315 & $<0.010$ & 0.029 & 2.12 & 1.78 & 0.748 & $<0.010$ & 86.4 & $<0.010$ & $<0.010$ & 6.57 & $<0.010$ & $<0.010$ & $<0.010$ \\
\hline
\end{tabular}


Table A-6. Condensate Cations Set 2 (mg/L)

\begin{tabular}{|c|c|c|c|c|c|c|c|c|c|c|c|c|c|c|c|c|c|c|c|c|}
\hline Sample ID & Lab ID & Al & B & Ba & $\mathbf{C a}$ & $\mathrm{Ce}$ & $\mathrm{Cr}$ & $\mathrm{Cu}$ & $\mathrm{Fe}$ & $\mathbf{K}$ & $\mathbf{L i}$ & Mg & Mn & $\mathrm{Na}$ & $\mathbf{N i}$ & $\mathbf{P b}$ & $\mathbf{S i}$ & $\mathbf{T i}$ & $\mathbf{Z n}$ & $\mathbf{Z r}$ \\
\hline CEF1-C-060 (A) & 3-0904 & 0.54 & 18.70 & $<0.010$ & 7.54 & $<0.010$ & 0.31 & $<0.010$ & 0.03 & 2.07 & 1.75 & 0.73 & $<0.010$ & 84.25 & $<0.010$ & $<0.010$ & 6.35 & $<0.010$ & $<0.010$ & $<0.010$ \\
\hline CEF1-C-060 (B) & 13-0904 & 0.52 & 18.69 & $<0.010$ & 7.50 & $<0.010$ & 0.31 & $<0.010$ & 0.03 & 2.06 & 1.74 & 0.73 & $<0.010$ & 85.64 & $<0.010$ & $<0.010$ & 6.27 & $<0.010$ & $<0.010$ & $<0.010$ \\
\hline CEF1-C-063 (A) & 13-0905 & 0.50 & 20.03 & $<0.010$ & 7.97 & $<0.010$ & 0.33 & $<0.010$ & 0.03 & 2.19 & 1.86 & 0.79 & $<0.010$ & 86.55 & $<0.010$ & $<0.010$ & 6.88 & $<0.010$ & $<0.010$ & $<0.010$ \\
\hline CEF1-C-063 (B) & 13-0905 & 0.52 & 19.84 & $<0.010$ & 7.86 & $<0.010$ & 0.33 & $<0.010$ & 0.03 & 2.15 & 1.83 & 0.78 & $<0.010$ & 87.23 & $<0.010$ & $<0.010$ & 6.83 & $<0.010$ & $<0.010$ & $<0.010$ \\
\hline CEF1-C-064 (A) & 13-0906 & 0.52 & 18.99 & $<0.010$ & 7.60 & $<0.010$ & 0.31 & $<0.010$ & 0.03 & 2.18 & 1.76 & 0.74 & $<0.010$ & 86.69 & $<0.010$ & $<0.010$ & 6.59 & $<0.010$ & $<0.010$ & $<0.010$ \\
\hline CEF1-C-064 (B) & 13-0906 & 0.53 & 19.29 & $<0.010$ & 7.73 & $<0.010$ & 0.31 & $<0.010$ & 0.03 & 2.21 & 1.79 & 0.75 & $<0.010$ & 87.42 & $<0.010$ & $<0.010$ & 6.69 & $<0.010$ & & \\
\hline CEF1-C-065 (A) & -0907 & 0.52 & 9.22 & $<0.010$ & 7.76 & $<0.010$ & 0.32 & $<0.010$ & 0.03 & 2.10 & 1.80 & 0.75 & $<0.010$ & 87.00 & $<0.010$ & $<0.010$ & 6.57 & & & \\
\hline CEF1-C-065 (B) & -0907 & 0.51 & 20.00 & $<0.01$ & 7.99 & $<0.010$ & 0.33 & $<0.010$ & 0.03 & 2.17 & 1.85 & & $<0.0$ & & & & 6.69 & & & \\
\hline CEF1-C-0 & & 0.53 & 82 & & 7.53 & & 0.31 & $<0$. & & 2.07 & 1.7 & & $<0$. & & & & 6.25 & & & \\
\hline CEF1 & 13 & 0.54 & 19.1 & & 7.61 & $<0.0$ & 0.31 & & & 2.09 & 1.78 & & & & & & 6.33 & & & $=0.010$ \\
\hline CEF1-C-06S & 13-0909 & 0.51 & 20.04 & $<0.010$ & 8.01 & $<0.010$ & 0.33 & $<0.010$ & 0.03 & 2.19 & 1.87 & 0.79 & $<0.010$ & 86.44 & $<0.010$ & $<0.010$ & 6.75 & $<0.010$ & $<0.010$ & $<0.010$ \\
\hline CEF1-C & 13-0909 & 0.55 & 20.25 & $<0.010$ & 8.02 & $<0.010$ & 0.33 & $<0.010$ & 0.03 & 2.19 & 1.86 & 0.79 & $<0.010$ & 87.16 & $<0.010$ & $<0.010$ & 6.72 & $<0.010$ & .010 & 0.010 \\
\hline CEF1- & -0910 & 0.55 & 19.69 & $<0.010$ & 7.78 & $<0.010$ & 0.32 & $<0.010$ & 0.03 & 2.13 & 1.81 & 0.76 & $<0.010$ & 88.59 & $<0.010$ & $<0.010$ & 6.52 & $<0.010$ & 10 & .010 \\
\hline CEF1-C & -0910 & 0.54 & 19.81 & $<0.010$ & 7.86 & $<0.010$ & 0.32 & $<0.010$ & 0.03 & 2.16 & 1.82 & 0.76 & $<0.010$ & 86.93 & $<0.010$ & $<0.010$ & 6.54 & $<0.010$ & $<0.010$ & $<0.010$ \\
\hline CEF1-C-076 (A) & $3-0911$ & 0.57 & 20.46 & $<0.010$ & 8.09 & $<0.010$ & 0.34 & $<0.010$ & 0.03 & 2.21 & 1.88 & 0.80 & $<0.010$ & 86.56 & $<0.010$ & $<0.010$ & 7.16 & $<0.010$ & $<0.010$ & $<0.010$ \\
\hline CEF1-C-076 (B) & $13-0911$ & 0.57 & 20.10 & $<0.010$ & 8.04 & $<0.010$ & 0.33 & $<0.010$ & 0.03 & 2.19 & 1.87 & 0.80 & $<0.010$ & 88.24 & $<0.010$ & $<0.010$ & 7.12 & $<0.010$ & $<0.010$ & $<0.010$ \\
\hline CEF1-C-082 (A) & 13-0912 & 0.63 & 18.97 & $<0.010$ & 7.63 & $<0.010$ & 0.32 & $<0.010$ & 0.03 & 2.09 & 1.78 & 0.75 & $<0.010$ & 86.93 & $<0.010$ & $<0.010$ & 6.70 & $<0.010$ & $<0.010$ & $<0.010$ \\
\hline CEF1-C-082 (B) & 13-0912 & 0.59 & 18.77 & $<0.010$ & 7.56 & $<0.010$ & 0.31 & $<0.010$ & 0.03 & 2.07 & 1.76 & 0.74 & $<0.010$ & 87.54 & $<0.010$ & $<0.010$ & 6.52 & $<0.010$ & $<0.010$ & $<0.010$ \\
\hline CEF1-C-088 (A) & 13-0913 & 0.45 & 25.69 & $<0.010$ & 8.03 & $<0.010$ & 0.35 & $<0.010$ & 0.03 & 2.69 & 2.46 & 0.93 & $<0.010$ & 111.26 & $<0.010$ & $<0.010$ & 5.89 & $<0.010$ & $<0.010$ & $<0.010$ \\
\hline CEF1-C-088 (B) & 13-0913 & 0.45 & 25.29 & $<0.010$ & 7.90 & $<0.010$ & 0.34 & $<0.010$ & 0.03 & 2.64 & 2.40 & 0.90 & $<0.010$ & 112.08 & $<0.010$ & $<0.010$ & 5.74 & $<0.010$ & $<0.010$ & $<0.010$ \\
\hline CEF1-C-094 (A) & 13-0914 & 0.48 & 27.95 & $<0.010$ & 7.82 & $<0.010$ & 0.34 & $<0.010$ & 0.03 & 2.74 & 2.54 & 0.91 & $<0.010$ & 115.96 & $<0.010$ & $<0.010$ & 5.99 & $<0.010$ & $<0.010$ & $<0.010$ \\
\hline CEF1-C-094 (B) & 13-0914 & 0.48 & 27.30 & $<0.010$ & 7.75 & $<0.010$ & 0.34 & $<0.010$ & 0.03 & 2.71 & 2.52 & 0.90 & $<0.010$ & 115.23 & $<0.010$ & $<0.010$ & 5.95 & $<0.010$ & $<0.010$ & $<0.010$ \\
\hline CEF1-C-100 (A) & $13-0915$ & 0.43 & 30.34 & $<0.010$ & 7.93 & $<0.010$ & 0.35 & $<0.010$ & 0.03 & 2.86 & 2.69 & 0.93 & $<0.010$ & 122.82 & $<0.010$ & $<0.010$ & 6.29 & $<0.010$ & $<0.010$ & $<0.010$ \\
\hline CEF1-C-100 (B) & $13-0915$ & 0.44 & 29.78 & $<0.010$ & 7.82 & $<0.010$ & 0.35 & $<0.010$ & 0.03 & 2.82 & 2.66 & 0.91 & $<0.010$ & 124.57 & $<0.010$ & $<0.010$ & 6.17 & $<0.010$ & $<0.010$ & $<0.010$ \\
\hline CEF1-C-108 (A) & $13-0916$ & 0.43 & 34.42 & $<0.010$ & 8.29 & $<0.010$ & 0.38 & & 0.03 & 3.16 & 2.98 & 0.99 & $<0.010$ & 129.33 & & & 6.56 & $<0.010$ & $<0$. & $<0.010$ \\
\hline CEF1-C-108 (B) & $13-0916$ & 0.42 & 33.95 & $<0.010$ & 8.19 & $<0.010$ & 0.37 & $<0.010$ & 0.03 & 3.15 & 2.97 & 0.97 & $<0.010$ & 128.87 & $<0.010$ & $<0.010$ & 6.47 & $<0.010$ & $<0.010$ & $<0.010$ \\
\hline
\end{tabular}


Table A-7. Condensate Supernate Anions (mg/L)

\begin{tabular}{|c|c|c|c|c|c|c|c|c|c|}
\hline Sample ID & Lab ID & $\mathbf{F}$ & Cl & $\mathrm{NO}_{2}$ & $\mathrm{NO}_{3}$ & $\mathrm{SO}_{4}$ & $\mathrm{PO}_{4}$ & $\mathrm{HCO}_{2}$ & $\mathrm{C}_{2} \mathrm{O}_{4}$ \\
\hline CEF1-C-023 (A) & $13-0891$ & $<1.00$ & $<1.00$ & $<1.00$ & $<1.00$ & $<1.00$ & $<1.00$ & $<1.00$ & $<1.00$ \\
\hline CEF1-C-023 (B) & 13-0891 & $<1.00$ & $<1.00$ & $<1.00$ & $<1.00$ & $<1.00$ & $<1.00$ & $<1.00$ & $<1.00$ \\
\hline CEF1-C-036 (A) & 13-0892 & $<1.00$ & $<1.00$ & $<1.00$ & $<1.00$ & $<1.00$ & $<1.00$ & $<1.00$ & $<1.00$ \\
\hline CEF1-C-036 (B) & 13-0892 & $<1.00$ & $<1.00$ & $<1.00$ & $<1.00$ & $<1.00$ & $<1.00$ & $<1.00$ & $<1.00$ \\
\hline CEF1-C-037 (A) & 13-0893 & $<1.00$ & $<1.00$ & $<1.00$ & $<1.00$ & $<1.00$ & $<1.00$ & $<1.00$ & $<1.00$ \\
\hline CEF1-C-037 (B) & 13-0893 & $<1.00$ & $<1.00$ & $<1.00$ & $<1.00$ & $<1.00$ & $<1.00$ & $<1.00$ & $<1.00$ \\
\hline CEF1-C-038 (A) & 13-0894 & $<1.00$ & $<1.00$ & $<1.00$ & $<1.00$ & $<1.00$ & $<1.00$ & $<1.00$ & $<1.00$ \\
\hline CEF1-C-038 (B) & 13-0894 & $<1.00$ & $<1.00$ & $<1.00$ & $<1.00$ & $<1.00$ & $<1.00$ & $<1.00$ & $<1.00$ \\
\hline CEF1-C-041 (A) & $13-0895$ & $<1.00$ & $<1.00$ & $<1.00$ & $<1.00$ & $<1.00$ & $<1.00$ & $<1.00$ & $<1.00$ \\
\hline CEF1-C-041 (B) & $13-0895$ & $<1.00$ & $<1.00$ & $<1.00$ & $<1.00$ & $<1.00$ & $<1.00$ & $<1.00$ & $<1.00$ \\
\hline CEF1-C-042 (A) & 13-0896 & $<1.00$ & $<1.00$ & $<1.00$ & $<1.00$ & $<1.00$ & $<1.00$ & $<1.00$ & $<1.00$ \\
\hline CEF1-C-042 (B) & 13-0896 & $<1.00$ & $<1.00$ & $<1.00$ & $<1.00$ & $<1.00$ & $<1.00$ & $<1.00$ & $<1.00$ \\
\hline CEF1-C-043 (A) & $13-0897$ & $<1.00$ & $<1.00$ & $<1.00$ & $<1.00$ & $<1.00$ & $<1.00$ & $<1.00$ & $<1.00$ \\
\hline CEF1-C-043 (B) & 13-0897 & $<1.00$ & $<1.00$ & $<1.00$ & $<1.00$ & $<1.00$ & $<1.00$ & $<1.00$ & $<1.00$ \\
\hline CEF1-C-044 (A) & 13-0898 & $<1.00$ & $<1.00$ & $<1.00$ & $<1.00$ & $<1.00$ & $<1.00$ & $<1.00$ & $<1.00$ \\
\hline CEF1-C-044 (B) & $13-0898$ & $<1.00$ & $<1.00$ & $<1.00$ & $<1.00$ & $<1.00$ & $<1.00$ & $<1.00$ & $<1.00$ \\
\hline CEF1-C-048 (A) & 13-0899 & $<1.00$ & $<1.00$ & $<1.00$ & $<1.00$ & $<1.00$ & $<1.00$ & $<1.00$ & $<1.00$ \\
\hline CEF1-C-048 (B) & 13-0899 & $<1.00$ & $<1.00$ & $<1.00$ & $<1.00$ & $<1.00$ & $<1.00$ & $<1.00$ & $<1.00$ \\
\hline CEF1-C-049 (A) & $13-0900$ & $<1.00$ & $<1.00$ & $<1.00$ & $<1.00$ & $<1.00$ & $<1.00$ & $<1.00$ & $<1.00$ \\
\hline CEF1-C-049 (B) & $13-0900$ & $<1.00$ & $<1.00$ & $<1.00$ & $<1.00$ & $<1.00$ & $<1.00$ & $<1.00$ & $<1.00$ \\
\hline CEF1-C-050 (A) & 13-0901 & $<1.00$ & $<1.00$ & $<1.00$ & $<1.00$ & $<1.00$ & $<1.00$ & $<1.00$ & $<1.00$ \\
\hline CEF1-C-050 (B) & 13-0901 & $<1.00$ & $<1.00$ & $<1.00$ & $<1.00$ & $<1.00$ & $<1.00$ & $<1.00$ & $<1.00$ \\
\hline CEF1-C-058 (A) & 13-0902 & $<1.00$ & $<1.00$ & $<1.00$ & $<1.00$ & $<1.00$ & $<1.00$ & $<1.00$ & $<1.00$ \\
\hline CEF1-C-058 (B) & $13-0902$ & $<1.00$ & $<1.00$ & $<1.00$ & $<1.00$ & $<1.00$ & $<1.00$ & $<1.00$ & $<1.00$ \\
\hline CEF1-C-059 (A) & $13-0903$ & $<1.00$ & $<1.00$ & $<1.00$ & $<1.00$ & $<1.00$ & $<1.00$ & $<1.00$ & $<1.00$ \\
\hline CEF1-C-059 (B) & 13-0903 & $<1.00$ & $<1.00$ & $<1.00$ & $<1.00$ & $<1.00$ & $<1.00$ & $<1.00$ & $<1.00$ \\
\hline CEF1-C-060 (A) & 13-0904 & $<1.00$ & $<1.00$ & $<1.00$ & $<1.00$ & $<1.00$ & $<1.00$ & $<1.00$ & $<1.00$ \\
\hline CEF1-C-060 (B) & 13-0904 & $<1.00$ & $<1.00$ & $<1.00$ & $<1.00$ & $<1.00$ & $<1.00$ & $<1.00$ & $<1.00$ \\
\hline CEF1-C-063 (A) & $13-0905$ & $<1.00$ & $<1.00$ & $<1.00$ & $<1.00$ & $<1.00$ & $<1.00$ & $<1.00$ & $<1.00$ \\
\hline CEF1-C-063 (B) & $13-0905$ & $<1.00$ & $<1.00$ & $<1.00$ & $<1.00$ & $<1.00$ & $<1.00$ & $<1.00$ & $<1.00$ \\
\hline CEF1-C-064 (A) & $13-0906$ & $<1.00$ & $<1.00$ & $<1.00$ & $<1.00$ & $<1.00$ & $<1.00$ & $<1.00$ & $<1.00$ \\
\hline CEF1-C-064 (B) & $13-0906$ & $<1.00$ & $<1.00$ & $<1.00$ & $<1.00$ & $<1.00$ & $<1.00$ & $<1.00$ & $<1.00$ \\
\hline CEF1-C-065 (A) & 13-0907 & $<1.00$ & $<1.00$ & $<1.00$ & $<1.00$ & $<1.00$ & $<1.00$ & $<1.00$ & $<1.00$ \\
\hline CEF1-C-065 (B) & $13-0907$ & $<1.00$ & $<1.00$ & $<1.00$ & $<1.00$ & $<1.00$ & $<1.00$ & $<1.00$ & $<1.00$ \\
\hline CEF1-C-068 (A) & $13-0908$ & $<1.00$ & $<1.00$ & $<1.00$ & $<1.00$ & $<1.00$ & $<1.00$ & $<1.00$ & $<1.00$ \\
\hline CEF1-C-068 (B) & 13-0908 & $<1.00$ & $<1.00$ & $<1.00$ & $<1.00$ & $<1.00$ & $<1.00$ & $<1.00$ & $<1.00$ \\
\hline CEF1-C-069 (A) & 13-0909 & $<1.00$ & $<1.00$ & $<1.00$ & $<1.00$ & $<1.00$ & $<1.00$ & $<1.00$ & $<1.00$ \\
\hline CEF1-C-069 (B) & 13-0909 & $<1.00$ & $<1.00$ & $<1.00$ & $<1.00$ & $<1.00$ & $<1.00$ & $<1.00$ & $<1.00$ \\
\hline CEF1-C-070 (A) & $13-0910$ & $<1.00$ & $<1.00$ & $<1.00$ & $<1.00$ & $<1.00$ & $<1.00$ & $<1.00$ & $<1.00$ \\
\hline CEF1-C-070 (B) & $13-0910$ & $<1.00$ & $<1.00$ & $<1.00$ & $<1.00$ & $<1.00$ & $<1.00$ & $<1.00$ & $<1.00$ \\
\hline CEF1-C-076(A) & 13-0911 & $<1.00$ & $<1.00$ & $<1.00$ & $<1.00$ & $<1.00$ & $<1.00$ & $<1.00$ & $<1.00$ \\
\hline CEF1-C-076 (B) & 13-0911 & $<1.00$ & $<1.00$ & $<1.00$ & $<1.00$ & $<1.00$ & $<1.00$ & $<1.00$ & $<1.00$ \\
\hline CEF1-C-082 (A) & 13-0912 & $<1.00$ & $<1.00$ & $<1.00$ & $<1.00$ & $<1.00$ & $<1.00$ & $<1.00$ & $<1.00$ \\
\hline CEF1-C-082 (B) & $13-0912$ & $<1.00$ & $<1.00$ & $<1.00$ & $<1.00$ & $<1.00$ & $<1.00$ & $<1.00$ & $<1.00$ \\
\hline CEF1-C-088 (A) & $13-0913$ & $<1.00$ & 1.07 & 1.24 & $<1.00$ & $<1.00$ & $<1.00$ & $<1.00$ & $<1.00$ \\
\hline CEF1-C-088 (B) & $13-0913$ & $<1.00$ & 1.07 & 1.24 & $<1.00$ & $<1.00$ & $<1.00$ & $<1.00$ & $<1.00$ \\
\hline CEF1-C-094 (A) & 13-0914 & $<1.00$ & 1.11 & 1.32 & $<1.00$ & $<1.00$ & $<1.00$ & $<1.00$ & $<1.00$ \\
\hline CEF1-C-094 (B) & 13-0914 & $<1.00$ & 1.11 & 1.31 & $<1.00$ & $<1.00$ & $<1.00$ & $<1.00$ & $<1.00$ \\
\hline CEF1-C-100 (A) & 13-0915 & $<1.00$ & 1.18 & 1.40 & $<1.00$ & $<1.00$ & $<1.00$ & $<1.00$ & $<1.00$ \\
\hline CEF1-C-100 (B) & $13-0915$ & $<1.00$ & 1.18 & 1.40 & $<1.00$ & $<1.00$ & $<1.00$ & $<1.00$ & $<1.00$ \\
\hline CEF1-C-108 (A) & 13-0916 & $<1.00$ & 1.27 & 1.50 & $<1.00$ & $<1.00$ & $<1.00$ & $<1.00$ & $<1.00$ \\
\hline CEF1-C-108 (B) & 13-0916 & $<1.00$ & 1.27 & 1.50 & $<1.00$ & $<1.00$ & $<1.00$ & $<1.00$ & $<1.00$ \\
\hline
\end{tabular}


Table A-8. Condensate Density, Total Solids and pH

\begin{tabular}{|c|c|c|c|c|}
\hline Sample ID & Lab ID & Density & Total Solids & pH \\
\hline CEF1-C-023 (A) & $13-0891$ & 0.9982 & \multirow{2}{*}{$<0.100$} & \multirow{2}{*}{7.94} \\
\hline CEF1-C-023 (B) & 13-0891 & 0.9982 & & \\
\hline CEF1-C-036 (A) & 13-0892 & 0.9982 & \multirow{2}{*}{$<0.100$} & \multirow{2}{*}{7.85} \\
\hline CEF1-C-036 (B) & 13-0892 & 0.9982 & & \\
\hline CEF1-C-037 (A) & 13-0893 & 0.9982 & \multirow{2}{*}{$<0.100$} & \multirow{2}{*}{7.86} \\
\hline CEF1-C-037 (B) & 13-0893 & 0.9982 & & \\
\hline CEF1-C-038 (A) & 13-0894 & 0.9982 & \multirow{2}{*}{$<0.100$} & \multirow{2}{*}{7.83} \\
\hline CEF1-C-038 (B) & 13-0894 & 0.9982 & & \\
\hline CEF1-C-041 (A) & 13-0895 & 0.9982 & \multirow{2}{*}{$<0.100$} & \multirow{2}{*}{7.85} \\
\hline CEF1-C-041 (B) & 13-0895 & 0.9982 & & \\
\hline CEF1-C-042 (A) & 13-0896 & 0.9982 & \multirow{2}{*}{$<0.100$} & \multirow{2}{*}{7.87} \\
\hline CEF1-C-042 (B) & 13-0896 & 0.9982 & & \\
\hline CEF1-C-043 (A) & 13-0897 & 0.9982 & \multirow{2}{*}{$<0.100$} & \multirow{2}{*}{7.84} \\
\hline CEF1-C-043 (B) & 13-0897 & 0.9982 & & \\
\hline CEF1-C-044 (A) & 13-0898 & 0.9982 & \multirow{2}{*}{$<0.100$} & \multirow{2}{*}{7.86} \\
\hline CEF1-C-044 (B) & 13-0898 & 0.9982 & & \\
\hline CEF1-C-048 (A) & 13-0899 & 0.9983 & \multirow{2}{*}{$<0.100$} & \multirow{2}{*}{7.79} \\
\hline CEF1-C-048 (B) & 13-0899 & 0.9983 & & \\
\hline CEF1-C-049 (A) & $13-0900$ & 0.9983 & \multirow{2}{*}{$<0.100$} & \multirow{2}{*}{7.74} \\
\hline CEF1-C-049 (B) & 13-0900 & 0.9983 & & \\
\hline CEF1-C-050 (A) & 13-0901 & 0.9983 & & 778 \\
\hline CEF1-C-050 (B) & 13-0901 & 0.9983 & $<0.100$ & 1.18 \\
\hline CEF1-C-058 (A) & 13-0902 & 0.9983 & & \\
\hline CEF1-C-058 (B) & 13-0902 & 0.9983 & $<0.100$ & 7.86 \\
\hline CEF1-C-059 (A) & 13-0903 & 0.9983 & $<0100$ & 783 \\
\hline CEF1-C-059 (B) & 13-0903 & 0.9983 & $<0.100$ & 1.83 \\
\hline CEF1-C-060 (A) & 13-0904 & 0.9983 & $<0100$ & 783 \\
\hline CEF1-C-060 (B) & 13-0904 & 0.9983 & $<0.100$ & 1.83 \\
\hline CEF1-C-063 (A) & 13-0905 & 0.9983 & $<0100$ & 781 \\
\hline CEF1-C-063 (B) & 13-0905 & 0.9983 & -0.100 & 1.01 \\
\hline CEF1-C-064 (A) & 13-0906 & 0.9983 & $<0100$ & 783 \\
\hline CEF1-C-064 (B) & 13-0906 & 0.9983 & -0.100 & 1.05 \\
\hline CEF1-C-065 (A) & 13-0907 & 0.9983 & $<0100$ & 783 \\
\hline CEF1-C-065 (B) & 13-0907 & 0.9983 & $<0.100$ & 1.83 \\
\hline CEF1-C-068 (A) & 13-0908 & 0.9983 & $<0.100$ & 785 \\
\hline CEF1-C-068 (B) & 13-0908 & 0.9983 & $<0.100$ & 1.85 \\
\hline CEF1-C-069 (A) & 13-0909 & 0.9983 & $<0100$ & 787 \\
\hline CEF1-C-069 (B) & 13-0909 & 0.9983 & & \\
\hline CEF1-C-070 (A) & 13-0910 & 0.9983 & $<0100$ & 784 \\
\hline CEF1-C-070 (B) & 13-0910 & 0.9983 & $<0.100$ & 7.84 \\
\hline CEF1-C-076 (A) & 13-0911 & 0.9983 & $<0100$ & 788 \\
\hline CEF1-C-076 (B) & 13-0911 & 0.9983 & & \\
\hline CEF1-C-082 (A) & 13-0912 & 0.9983 & $<0100$ & 795 \\
\hline CEF1-C-082 (B) & $13-0912$ & 0.9983 & & 1.95 \\
\hline CEF1-C-088 (A) & 13-0913 & 0.9985 & $<0100$ & 784 \\
\hline CEF1-C-088 (B) & 13-0913 & 0.9985 & & \\
\hline CEF1-C-094 (A) & 13-0914 & 0.9985 & & 787 \\
\hline CEF1-C-094 (B) & 13-0914 & 0.9985 & .100 & 1.01 \\
\hline CEF1-C-100 (A) & $13-0915$ & 0.9985 & $<0) 100$ & 780 \\
\hline CEF1-C-100 (B) & $13-0915$ & 0.9985 & & \\
\hline CEF1-C-108 (A) & 13-0916 & 0.9985 & $<0100$ & 775 \\
\hline CEF1-C-108 (B) & 13-0916 & 0.9985 & $<0.100$ & 1.15 \\
\hline
\end{tabular}


SRNL-STI-2014-00005

Revision 0

Table A-9. Condensate Carbon Content

\begin{tabular}{ccccc}
\hline Sample ID & Lab ID & $\begin{array}{c}\text { Total Carbon } \\
(\mathbf{u g} / \mathbf{m L})\end{array}$ & $\begin{array}{c}\text { Organic Carbon } \\
(\mathbf{u g} / \mathbf{m L})\end{array}$ & $\begin{array}{c}\text { Inorganic Carbon } \\
\text { (ug/mL) }\end{array}$ \\
\hline CEF1-C-023 & 300305110 & 63.7 & 22.1 & 41.6 \\
\hline CEF1-C-036 & 300305111 & 62.3 & 21.9 & 40.4 \\
\hline CEF1-C-037 & 300305112 & 63.4 & 22 & 41.6 \\
\hline CEF1-C-038 & 300305113 & 62.5 & 21.3 & 41.2 \\
\hline CEF1-C-041 & 300305114 & 63.6 & 22 & 41.6 \\
\hline CEF1-C-042 & 300305115 & 61.9 & 21.9 & 40 \\
\hline CEF1-C-043 & 300305116 & 64.3 & 21.4 & 42.9 \\
\hline CEF1-C-044 & 300305117 & 61.8 & 21.8 & 40 \\
\hline CEF1-C-048 & 300305118 & 65.6 & 21.6 & 44 \\
\hline CEF1-C-049 & 300305119 & 67.8 & 22.3 & 45.5 \\
\hline CEF1-C-050 & 300305120 & 67.3 & 22.9 & 44.4 \\
\hline CEF1-C-058 & 300305121 & 74.7 & 25.2 & 51.1 \\
\hline CEF1-C-059 & 300305122 & 76.1 & 25 & 49.3 \\
\hline CEF1-C-060 & 300305123 & 75.2 & 25.9 & 50.4 \\
\hline CEF1-C-063 & 300305124 & 75.8 & 25.4 & \\
\hline
\end{tabular}


Table A-10. Filter Solids Cations (wt\%)

\begin{tabular}{|c|c|c|c|c|c|c|c|c|c|c|c|c|c|c|c|c|c|c|c|c|}
\hline Sample ID & Lab ID & Al & B & $\mathbf{B a}$ & $\mathbf{C a}$ & $\mathrm{Ce}$ & $\mathrm{Cr}$ & $\mathbf{C u}$ & $\mathbf{F e}$ & $\mathbf{K}$ & $\mathbf{L i}$ & Mg & Mn & $\mathbf{N a}$ & $\mathbf{N i}$ & $\mathbf{P b}$ & Si & $\mathbf{T i}$ & $\mathbf{Z n}$ & $\mathbf{Z r}$ \\
\hline CEF1-FL-A (A) & $13-0931$ & 9.90 & 0.754 & 0.101 & 0.614 & 0.109 & 0.141 & 0.115 & 20.0 & 0.044 & 0.800 & 0.658 & 6.10 & 2.98 & 2.58 & $<0.100$ & 10.8 & 0.041 & 0.090 & 0.116 \\
\hline CEF1-FL-A (B) & $13-0931$ & 9.82 & 0.737 & 0.101 & 0.633 & 0.111 & 0.142 & 0.142 & 19.7 & 0.043 & 0.814 & 0.662 & 6.04 & 2.99 & 2.55 & $<0.100$ & 10.9 & 0.041 & 0.091 & 0.107 \\
\hline CEF1-FL-M (A) & 13-0932 & 8.21 & 0.855 & 0.085 & 0.543 & 0.098 & 0.175 & 0.124 & 16.9 & 0.046 & 1.04 & 0.597 & 5.16 & 3.27 & 2.20 & $<0.100$ & 13.1 & 0.043 & 0.084 & 0.104 \\
\hline CEF1-FL-M (B) & $13-0932$ & 8.23 & 0.849 & 0.081 & 0.538 & 0.097 & 0.172 & 0.106 & 16.8 & 0.042 & 1.03 & 0.572 & 5.12 & 3.20 & 2.19 & $<0.100$ & 12.9 & 0.059 & 0.080 & 0.115 \\
\hline CEF1-FL-Q (A) & $13-0933$ & 8.70 & 0.578 & 0.090 & 0.746 & 0.111 & 0.171 & 0.133 & 20.1 & 0.050 & 0.524 & 0.727 & 6.52 & 2.34 & 2.67 & $<0.100$ & 10.6 & 0.046 & 0.096 & 0.090 \\
\hline CEF1-FL-Q (B) & $13-0933$ & 8.59 & 0.568 & 0.086 & 0.754 & 0.107 & 0.165 & 0.121 & 19.9 & 0.050 & 0.507 & 0.719 & 6.49 & 2.33 & 2.64 & $<0.100$ & 10.3 & 0.055 & 0.094 & 0.093 \\
\hline CEF1-FL-B (A) & $13-0934$ & 8.82 & 0.713 & 0.099 & 0.655 & 0.104 & 1.26 & 0.115 & 19.2 & 0.052 & 0.735 & 0.647 & 5.87 & 2.88 & 2.55 & $<0.100$ & 11.1 & 0.065 & 0.089 & 0.091 \\
\hline CEF1-FL-B (B) & 13-0934 & 8.72 & 0.708 & 0.098 & 0.653 & 0.109 & 1.29 & 0.111 & 19.2 & 0.051 & 0.740 & 0.647 & 5.85 & 2.76 & 2.57 & $<0.100$ & 10.8 & 0.064 & 0.087 & 0.083 \\
\hline
\end{tabular}

\section{Table A-11. Filter Solids Anions (wt\%)}

\begin{tabular}{cccccccccc}
\hline Sample ID & Lab ID & $\mathbf{F}$ & $\mathbf{C l}$ & $\mathbf{N O}_{2}$ & $\mathbf{N O}_{3}$ & $\mathbf{S O}_{4}$ & $\mathbf{C}_{2} \mathrm{O}_{4}$ & $\mathbf{H C O}_{2}$ & PO4 $_{4}$ \\
\hline CEF1-FL-A (A) & $13-0931$ & $<0.050$ & $<0.050$ & $<0.050$ & $<0.050$ & 0.148 & 0.168 & $<0.050$ & $<0.050$ \\
\hline CEF1-FL-A (B) & $13-0931$ & $<0.050$ & $<0.050$ & $<0.050$ & $<0.050$ & 0.145 & 0.120 & $<0.050$ & $<0.050$ \\
\hline CEF1-FL-M (A) & $13-0932$ & $<0.050$ & 0.224 & $<0.050$ & $<0.050$ & 0.126 & 0.615 & $<0.050$ & $<0.050$ \\
\hline CEF1-FL-M (B) & $13-0932$ & $<0.050$ & 0.254 & $<0.050$ & $<0.050$ & 0.122 & 0.565 & $<0.050$ & $<0.050$ \\
\hline CEF1-FL-Q (A) & $13-0933$ & $<0.050$ & 0.201 & $<0.050$ & $<0.050$ & 0.177 & 0.610 & $<0.050$ & $<0.050$ \\
\hline CEF1-FL-Q (B) & $13-0933$ & $<0.050$ & 0.213 & $<0.050$ & $<0.050$ & 0.169 & 0.635 & $<0.050$ & $<0.050$ \\
\hline CEF1-FL-B (A) & $13-0934$ & $<0.050$ & 0.071 & $<0.050$ & $<0.050$ & 0.206 & 0.294 & $<0.050$ & $<0.050$ \\
\hline CEF1-FL-B (B) & $13-0934$ & $<0.050$ & 0.071 & $<0.050$ & $<0.050$ & 0.205 & 0.230 & $<0.050$ & $<0.050$ \\
\hline
\end{tabular}

Table A-12. Filter Solids

\begin{tabular}{ccc}
\hline Sample ID & Lab ID & Total Solids \\
\hline CEF1-FL-A (A) & $13-0931$ & $96.5 \%$ \\
\hline CEF1-FL-A (B) & $13-0931$ & $96.6 \%$ \\
\hline CEF1-FL-M (A) & $13-0932$ & $97.2 \%$ \\
\hline CEF1-FL-M (B) & $13-0932$ & $97.2 \%$ \\
\hline CEF1-FL-Q (A) & $13-0933$ & $96.0 \%$ \\
\hline CEF1-FL-Q (B) & $13-0933$ & $96.0 \%$ \\
\hline CEF1-FL-B (A) & $13-0934$ & $96.9 \%$ \\
\hline CEF1-FL-B (B) & $13-0934$ & $96.8 \%$ \\
\hline
\end{tabular}


Table A-13. ICP-AES Glass Analysis (wt\%)

\begin{tabular}{ccccccccccc}
\hline Sample ID & Lab ID & Al & B & Ba & Ca & Ce & Cr & Cu & Fe & K \\
\hline CEF1-GL-005 (A) & $13-0859$ & 5.40956 & 1.431 & 0.030209 & 0.404763 & 0.036845 & 0.053209 & 0.060378 & 7.35328 & 0.08405 \\
\hline CEF1-GL-005 (B) & $13-0859$ & 5.35599 & 1.547 & 0.044584 & 0.405513 & 0.040013 & 0.057211 & 0.060969 & 7.34148 & 0.087101 \\
\hline CEF1-GL-007 (A) & $13-0860$ & 5.32258 & 1.566 & 0.039042 & 0.420612 & 0.047583 & 0.054192 & 0.05406 & 7.39566 & 0.096357 \\
\hline CEF1-GL-007 (B) & $13-0860$ & 5.22755 & 1.56 & 0.038465 & 0.418896 & 0.04707 & 0.053003 & 0.061949 & 7.30665 & 0.098461 \\
\hline CEF1-GL-008 (A) & $13-0861$ & 5.22007 & 1.547 & 0.040333 & 0.423539 & 0.049585 & 0.059285 & 0.053275 & 7.40302 & 0.096784 \\
\hline CEF1-GL-008 (B) & $13-0861$ & 5.24782 & 1.553 & 0.040329 & 0.425068 & 0.049679 & 0.059841 & 0.052856 & 7.42605 & 0.09876 \\
\hline CEF1-GL-009 (A) & $13-0862$ & 5.09263 & 1.465 & 0.04183 & 0.420114 & 0.05072 & 0.060489 & 0.052595 & 7.24938 & 0.099095 \\
\hline CEF1-GL-009 (B) & $13-0862$ & 5.15232 & 1.294 & 0.041327 & 0.420428 & 0.050259 & 0.06016 & 0.049952 & 7.42986 & 0.095607 \\
\hline CEF1-GL-014 (A) & $13-0863$ & 5.13854 & 1.526 & 0.047641 & 0.414774 & 0.057319 & 0.06964 & 0.054505 & 7.53094 & 0.106703 \\
\hline CEF1-GL-014 (B) & $13-0863$ & 5.11352 & 1.583 & 0.047608 & 0.415383 & 0.057195 & 0.069433 & 0.057031 & 7.47859 & 0.105287 \\
\hline CEF1-GL-016 (A) & $13-0864$ & 5.07529 & 1.593 & 0.049154 & 0.420639 & 0.058123 & 0.071624 & 0.050933 & 7.45518 & 0.108126 \\
\hline CEF1-GL-016 (B) & $13-0864$ & 5.0831 & 1.581 & 0.049264 & 0.422427 & 0.058508 & 0.071442 & 0.053363 & 7.50899 & 0.108592 \\
\hline
\end{tabular}

\begin{tabular}{cccccccccccc}
\hline Sample ID & Lab ID & Li & Mg & Mn & Na & Ni & Pb & Si & Ti & $\mathbf{Z n}$ \\
\hline CEF1-GL-005 (A) & $13-0859$ & 2.16 & 0.283 & 2.41 & 9.10 & 0.962 & $<0.100$ & 23.3 & 0.021 & 0.031 & 0.100 \\
\hline CEF1-GL-005 (B) & $13-0859$ & 2.25 & 0.284 & 2.39 & 9.07 & 0.963 & $<0.100$ & 23.3 & 0.021 & 0.031 & 0.101 \\
\hline CEF1-GL-007 (A) & $13-0860$ & 2.27 & 0.318 & 2.44 & 8.97 & 0.951 & $<0.100$ & 23.7 & 0.025 & 0.036 & 0.118 \\
\hline CEF1-GL-007 (B) & $13-0860$ & 2.28 & 0.313 & 2.41 & 8.88 & 0.942 & $<0.100$ & 23.8 & 0.022 & 0.035 & 0.106 \\
\hline CEF1-GL-008 (A) & $13-0861$ & 2.25 & 0.321 & 2.42 & 8.87 & 0.963 & $<0.100$ & 23.7 & 0.025 & 0.037 & 0.105 \\
\hline CEF1-GL-008 (B) & $13-0861$ & 2.27 & 0.323 & 2.43 & 8.90 & 0.974 & $<0.100$ & 23.5 & 0.027 & 0.037 & 0.120 \\
\hline CEF1-GL-009 (A) & $13-0862$ & 2.19 & 0.323 & 2.38 & 8.68 & 0.969 & $<0.100$ & 22.8 & 0.026 & 0.037 & 0.121 \\
\hline CEF1-GL-009 (B) & $13-0862$ & 2.10 & 0.321 & 2.40 & 8.78 & 0.955 & $<0.100$ & 22.8 & 0.026 & 0.037 & 0.116 \\
\hline CEF1-GL-014 (A) & $13-0863$ & 2.22 & 0.342 & 2.46 & 8.73 & 0.989 & $<0.100$ & 23.4 & 0.023 & 0.046 & 0.107 \\
\hline CEF1-GL-014 (B) & $13-0863$ & 2.28 & 0.341 & 2.44 & 8.63 & 0.985 & $<0.100$ & 24.1 & 0.023 & 0.047 & 0.106 \\
\hline CEF1-GL-016 (A) & $13-0864$ & 2.27 & 0.349 & 2.44 & 8.67 & 0.999 & $<0.100$ & 23.1 & 0.023 & 0.045 & 0.108 \\
\hline CEF1-GL-016 (B) & $13-0864$ & 2.26 & 0.349 & 2.45 & 8.76 & 0.997 & $<0.100$ & 23.9 & 0.024 & 0.046 & 0.108 \\
\hline
\end{tabular}


Table A-14. Glass REDOX

\begin{tabular}{|c|c|c|c|c|c|c|}
\hline Sample & Lab ID & $\mathrm{Fe}^{2+}$ & $\mathrm{Fe}^{3+}$ & $\sum \mathbf{F e}$ & $\mathrm{Fe}^{2+} / \mathrm{Fe}^{3+}$ & $\mathrm{Fe}^{2+} / \sum \mathrm{Fe}$ \\
\hline EA & --- & 0.065 & 0.279 & 0.344 & 0.233 & 0.189 \\
\hline CEF1-GL-001 (A) & \multirow{2}{*}{$13-0865$} & 0.038 & 0.467 & 0.505 & 0.081 & 0.075 \\
\hline CEF1-GL-001 (B) & & 0.039 & 0.467 & 0.506 & 0.084 & 0.077 \\
\hline CEF1-GL-002 (A) & \multirow{2}{*}{$13-0866$} & 0.043 & 0.395 & 0.438 & 0.109 & 0.098 \\
\hline CEF1-GL-002 (B) & & 0.044 & 0.396 & 0.440 & 0.111 & 0.100 \\
\hline CEF1-GL-003 (A) & \multirow{2}{*}{$13-0867$} & 0.058 & 0.380 & 0.438 & 0.153 & 0.132 \\
\hline CEF1-GL-003 (B) & & 0.058 & 0.383 & 0.441 & 0.151 & 0.132 \\
\hline CEF1-GL-004 (A) & \multirow{2}{*}{$13-0868$} & 0.081 & 0.401 & 0.482 & 0.202 & 0.168 \\
\hline CEF1-GL-004 (B) & & 0.083 & 0.400 & 0.483 & 0.208 & 0.172 \\
\hline CEF1-GL-005 (A) & \multirow{2}{*}{$13-0869$} & 0.084 & 0.426 & 0.510 & 0.197 & 0.165 \\
\hline CEF1-GL-005 (B) & & 0.084 & 0.423 & 0.507 & 0.199 & 0.166 \\
\hline CEF1-GL-006 (A) & \multirow{2}{*}{$13-0870$} & 0.092 & 0.415 & 0.507 & 0.222 & 0.181 \\
\hline CEF1-GL-006 (B) & & 0.093 & 0.415 & 0.508 & 0.224 & 0.183 \\
\hline CEF1-GL-007 (A) & \multirow{2}{*}{ 13-0871 } & 0.083 & 0.418 & 0.501 & 0.199 & 0.166 \\
\hline CEF1-GL-007 (B) & & 0.084 & 0.417 & 0.501 & 0.201 & 0.168 \\
\hline CEF1-GL-008 (A) & \multirow{2}{*}{$13-0872$} & 0.059 & 0.378 & 0.437 & 0.156 & 0.135 \\
\hline CEF1-GL-008 (B) & & 0.059 & 0.379 & 0.438 & 0.156 & 0.135 \\
\hline CEF1-GL-009 (A) & \multirow{2}{*}{$13-0873$} & 0.053 & 0.422 & 0.475 & 0.126 & 0.112 \\
\hline CEF1-GL-009 (B) & & 0.054 & 0.423 & 0.477 & 0.128 & 0.113 \\
\hline CEF1-GL-010 (A) & \multirow{2}{*}{$13-0874$} & 0.045 & 0.485 & 0.530 & 0.093 & 0.085 \\
\hline CEF1-GL-010 (B) & & 0.047 & 0.483 & 0.530 & 0.097 & 0.089 \\
\hline CEF1-GL-011 (A) & \multirow{2}{*}{$13-0875$} & 0.057 & 0.398 & 0.455 & 0.143 & 0.125 \\
\hline CEF1-GL-011 (B) & & 0.057 & 0.401 & 0.458 & 0.142 & 0.124 \\
\hline CEF1-GL-012 (A) & \multirow{2}{*}{$13-0876$} & 0.075 & 0.409 & 0.484 & 0.183 & 0.155 \\
\hline CEF1-GL-012 (B) & & 0.075 & 0.409 & 0.484 & 0.183 & 0.155 \\
\hline CEF1-GL-013 (A) & \multirow{2}{*}{$13-0877$} & 0.076 & 0.385 & 0.461 & 0.197 & 0.165 \\
\hline CEF1-GL-013 (B) & & 0.075 & 0.388 & 0.463 & 0.193 & 0.162 \\
\hline CEF1-GL-014 (A) & \multirow{2}{*}{$13-0878$} & 0.093 & 0.356 & 0.449 & 0.261 & 0.207 \\
\hline CEF1-GL-014 (B) & & 0.089 & 0.361 & 0.450 & 0.247 & 0.198 \\
\hline CEF1-GL-015 (A) & \multirow{2}{*}{ 13-0879 } & 0.091 & 0.395 & 0.486 & 0.230 & 0.187 \\
\hline CEF1-GL-015 (B) & & 0.092 & 0.397 & 0.489 & 0.232 & 0.188 \\
\hline CEF1-GL-016 (A) & \multirow{2}{*}{$13-0880$} & 0.092 & 0.413 & 0.505 & 0.223 & 0.182 \\
\hline CEF1-GL-016 (B) & & 0.093 & 0.411 & 0.504 & 0.226 & 0.185 \\
\hline
\end{tabular}




\section{Distribution:}

S. L. Marra

D.H. McGuire

T. B. Brown

S. D. Fink

C. C. Herman

E. N. Hoffman

F. M. Pennebaker

W. R. Wilmarth

Records Administration (EDWS)

J. M. Bricker

T. L. Fellinger

E. J. Freed

J. M. Gillam

B. A. Hamm

E. W. Holtzscheiter

J. F. Iaukea

D. K. Peeler

J. W. Ray

P. J. Ryan

H. B. Shah

D. C. Sherburne

M. E. Stone

P. R. Jackson, DOE-SR

K. H. Subramanian

D.H. Miller

J.R. Zamecnik

D.P. Lambert

F.C. Johnson

J.M. Pareizs

J.D. Newell

A.S. Choi

W.O. Pepper Jr.

S.T. Isom

J.R. Vitali 